University of Rhode Island

DigitalCommons@URI

Open Access Master's Theses

1979

\title{
Marina Study: Marina Facilities Planning At Two Case Study Locations
}

Bruce Dean Bender

University of Rhode Island

David Smith Windsor

University of Rhode Island

Follow this and additional works at: https://digitalcommons.uri.edu/theses

\section{Recommended Citation}

Bender, Bruce Dean and Windsor, David Smith, "Marina Study: Marina Facilities Planning At Two Case Study Locations" (1979). Open Access Master's Theses. Paper 507.

https://digitalcommons.uri.edu/theses/507

This Thesis is brought to you for free and open access by DigitalCommons@URI. It has been accepted for inclusion in Open Access Master's Theses by an authorized administrator of DigitalCommons@URI. For more information, please contact digitalcommons-group@uri.edu. 


\author{
MARINA STUDY: \\ MARINA FACILITIES PLANNING \\ AT \\ TWO CASE STUDY LOCATIONS
}

by

BRUCE DEAN BENDER

DAVID SMITH WINSOR

A MASTERS RESEARCH PROJECT

UNIVERSITY OF RHODE ISLAND

1979 
SUBMITTED IN PARTIAL FULFILLMENT

OF THE REQUIREMENTS FOR THE

DEGREE OF

MASTER OF COMMUNITY PLANNING

APPROVED:

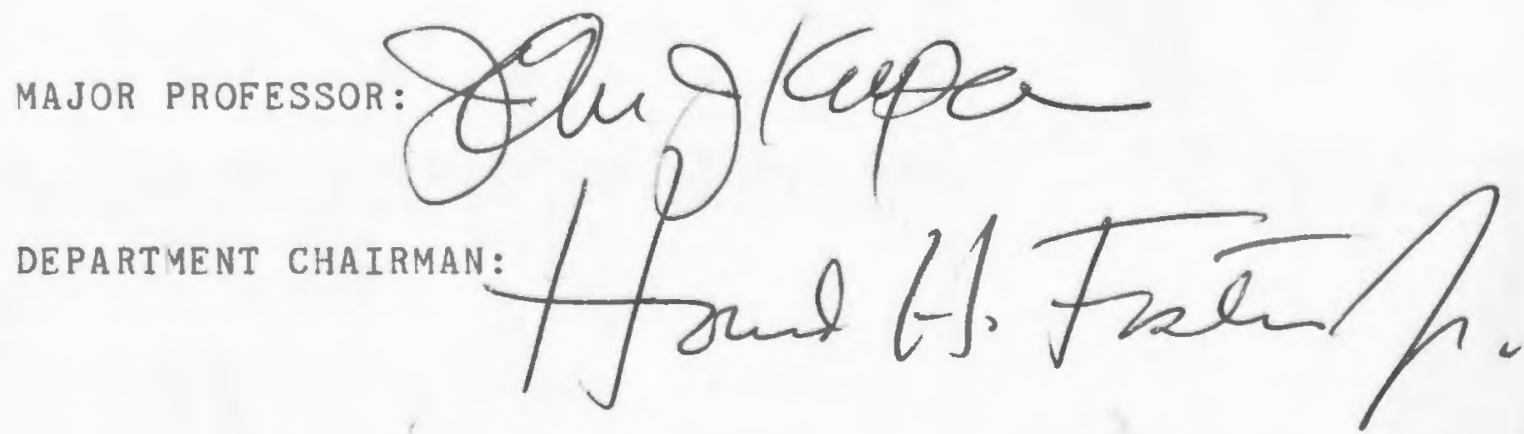




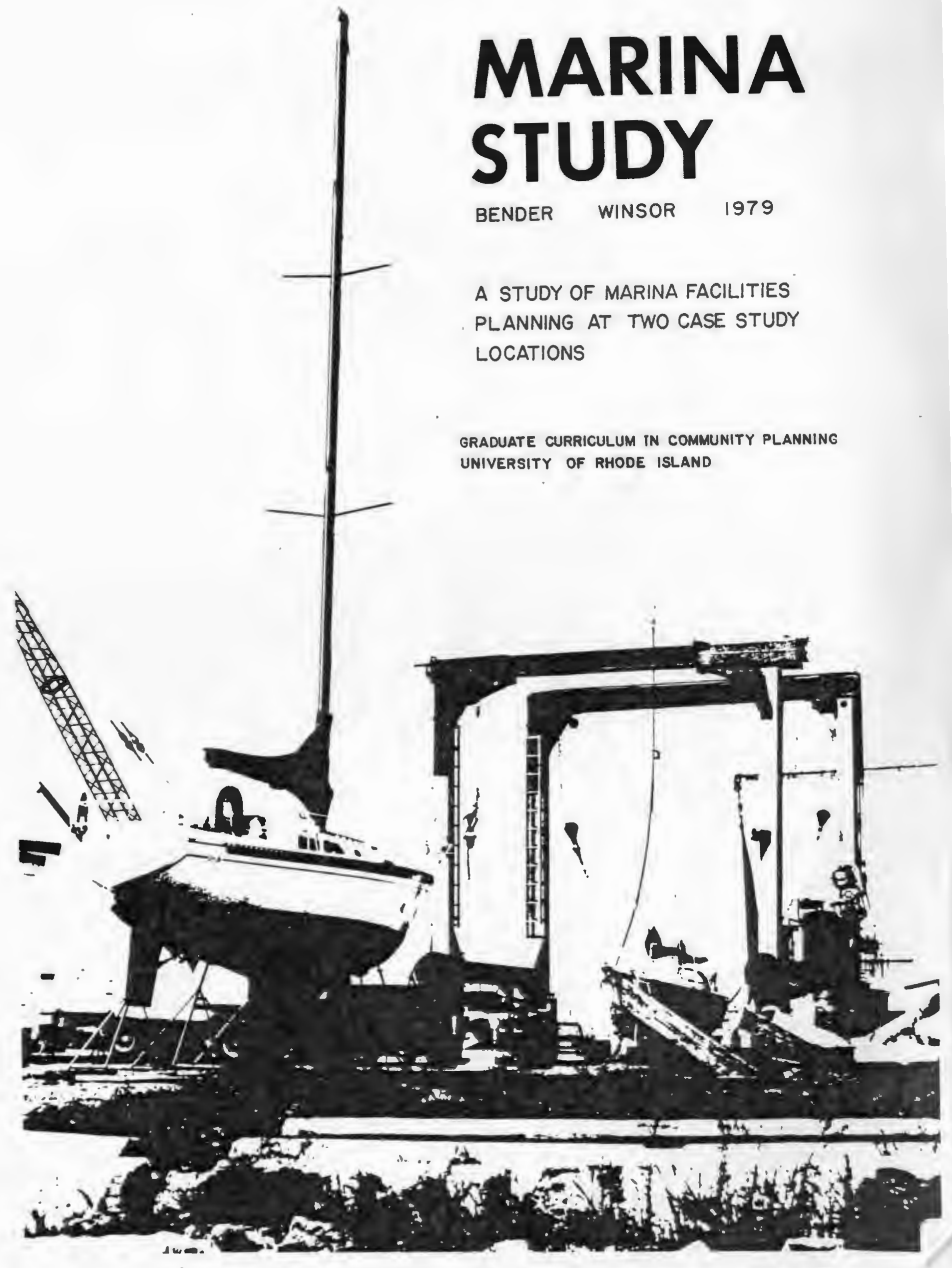


Acknowledgenerts:

We wish to express our gratitude to all those who assisted us ir this effort. Special thanks to:

$$
\text { Dr. John J. Kupa }
$$

our major professor, whose guidance and inspiration have been a source of motivation during our time as his studer.ts.

\section{Neil Ross}

from whose fertile brair. the germ of this project originated, who has beer most helpful ir brirging it to fruition.

We also wish to thank the owners of the two case study mariras, Mr. Ton Kingmar of Cataumet Marina, ard Comnarder and Mrs. Steven Wood of Store Cove Marira, who have been a pleasure to work with.

Debby Truitt of the New England Marine Advisory Service deserves tharks for putting up with our delirquert provisior. of material for her excellent Marira Desigr. Corference in Bostor. in early December of 1979. Gail Chmura of The Rhode Island Department of Environmental Management and Mike Penny of the Massachusetts Costal Zore Maragement program provided informatior on the permit process.

Finally, we never would have nade it without Barbara Simor, who provided help with proofreading, graphics, editirg, and typing, and ar occasional hot meal wher it was reeded most. 
TABLE OF CONTENTS

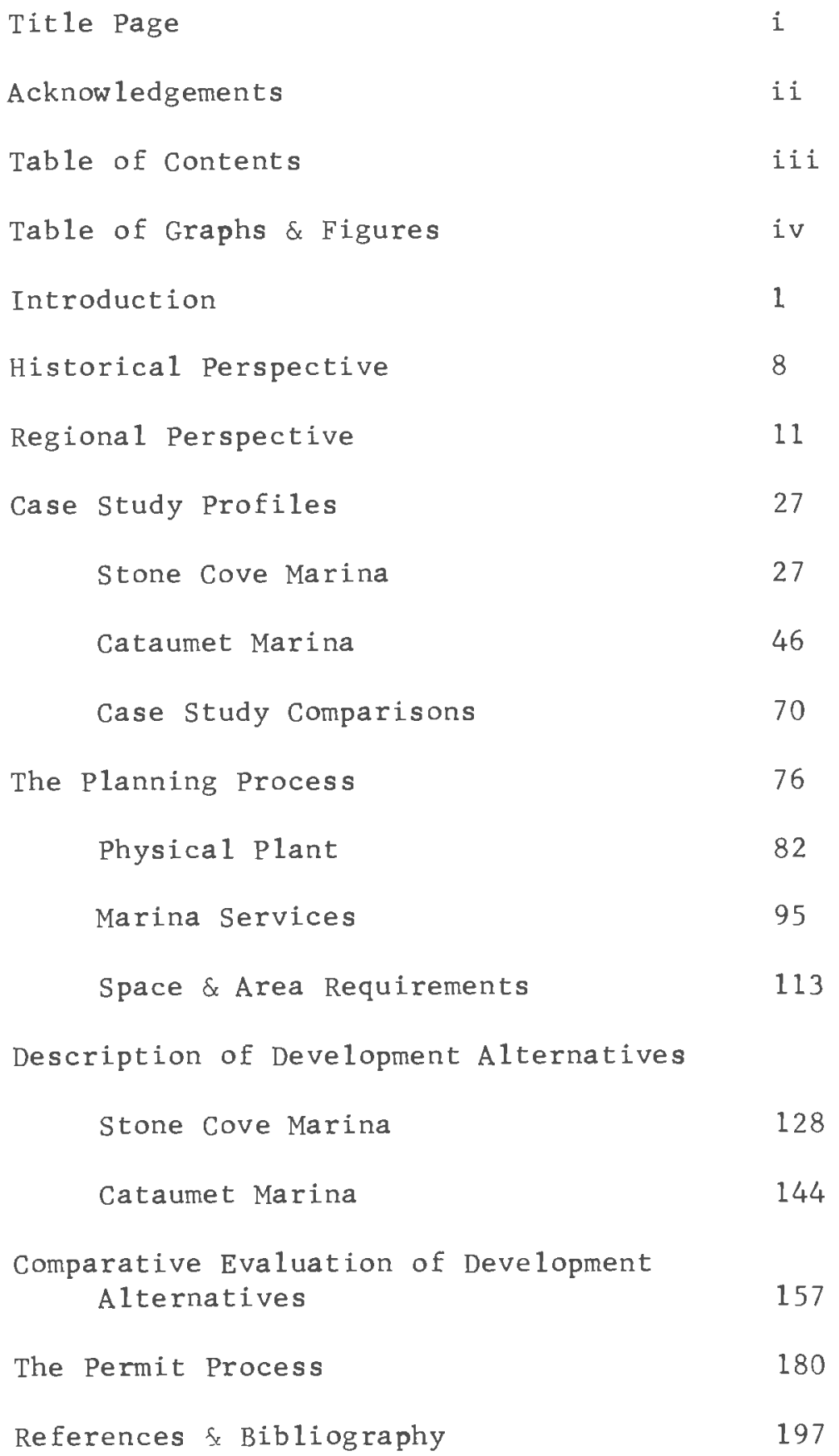


TABLE OF GRAPHS \& FIGURES*

Figure 非

I1

I2

I3

I4

P1

$\mathrm{P} 2$

P 3

$\mathrm{P} 4 \mathrm{~A}$

$\mathrm{P} 4 \mathrm{~B}$

P5

P6

P7

P8

P9

$\mathrm{P} 10 \mathrm{~A}$

P10B

P 11

P12

P13

P 14

P15

P16

$\mathrm{P} 17$

P18

$\mathrm{P} 19$

$\mathrm{P} 20$

$\mathrm{P} 21$

$\mathrm{P} 22$

$\mathrm{P} 23$

$\mathrm{P} 24$

$\mathrm{P} 25 \mathrm{~A}$

$\mathrm{P} 25 \mathrm{~B}$
Description

Page 非

REGIONAL_PERSPECTIVE

Activity Area Comparison, Narragansett

Bay \& Buzzards Bay

23

Boats vs. 非 of Services, Narragansett Bay 24

Boats vs. 非 of Services, Buzzard's Bay 25

Distribution by Length, Narragansett Bay 26

\section{CASE STUDY PROFILES}

STONE COVE MARINA

Location of Case Study Marinas 36

Point Judith Pond Area 37

Stone Cove Marina Layout 38

Stone Cove Marina Distribution of Slips 39

Stone Cove Marina Gasoline Allocations 39

Stone Cove Marina Customer Distribution 40

Distance of Seasonal Boat Owners from

Stone Cove Marina 41

Towns with more than one customer -

Stone Cove Marina 41

Driving Distances and Average Times 42

Distribution of Boats by Length - Stone Cove 43

Winterization: Outboards (Zates at Stone Cove) 44

Storage Charges $f$ Other Fees (Stone Cove) 45

\section{CATAUMET MARINA}

Red Brook Harbor Area $\quad 56$

Cape Cod \& The Islands 57

Cataumet Marina Layout 58

(no figure)

Zoning around Cataumet Marina 59

Cataumet Marina Organizational Chart 60

Distribution of Slips - Cataumet Marina 61

Marina Facilities Checklist

(Stone Cove vs. Cataumet) 62

Fuel Sales - Cataumet Marina 61

Cataumet Marina Customer Distribution 63

Distance of Seasonal Boat Owners from Cataumet 64

Towns with more than one customer - Cataumet 64

Distribution of Boats by Length - (Cataumet) 65

Seasonal Boats by Length \& Type 66

Cataumet Marina, Rates 67

Kingman Marine, Inc., Rates 68,69

* Graphs and Figures follow the text of each Section 
TABLE OF GRAPHS \& FIGURES (continued)

Figure 非

E5

E6

E7

E8

E9
Description

THE PERMIT PROCESS (continued)

Army Corps Permit Review Process

Massachusetts Loca1 Government Permit

Process

Massachusetts Executive Office of

Environmental Affairs - Structure

EOEA Permit App1ication Procedures

Important Addresses $\delta$ Phone Numbers
192

Page 非

193

194

195

196 


\section{INT RODUCTION}

The popularity and intensity of recreational boating in the waters of southern New England has been steadily increasing since the 1960's, Despite regional economic fluctuations, the level of boating activity continues to grow. Forecasts of boat ownership clearly indicate that the demand for moorings and slips in Rhode Island and Massachusetts will exceed the present capacity of shore facilities and their ability to increase that capacity to meet the denands for an expanded level of service (Collins \& Sedgwick, 1979).

A study entitled "Marinas and Pleasure Boating Facilities Study" Rhode Island Department of Economic Development, October 1975, indicates that projected boat ownership trends for boats over 16 feet in length in Southern New England will increase by 8,700 boats from 1975 to $1980,9,900$ boats from 1980 to 1985 and 11,200 boats from 1985 to 1990 (Urban Design Group, 1975).

While it would appear that the volume of activity alone would be sufficient cause to expect that the suppliers of boating services will enjoy a market advantage, there are economic and physical forces at work which present difficult planning questions for those responsible for the development of marina facilities. The scope and character of boating support facilities is now shaped by the changing needs of the users as they, themselves adapt to prevailing economic circumstances. 
The economic realitifs of successful marina operation suggest that boating facilities are no longer simply installations for the mooring and berthing of pleasure boats. Upon examination, those facilities which produce a viable economic return are found to be based on a complex formula of economic and operational variables acting in concert to produce an attractive marketable boating resource to a regionally dispersed consumer demand.

Having evolved from a rather utilitarian past, the contemporary marina can possess a more cosmopolitan identity often functioning as a recreational center in which service to the boating public is but one of its many commercial functions. Full service marinas are now appearing that offer services which go well beyond the fundamental functions of boatyards and private clubs.

secondly, the combined pressures of neighboring development and environmental manaqement have imposed a new dimension on the planning and operation of recreational boating facilities. Consequently, the interface of land and water that is both physically suitable and available as sites for boating installations is a vanishing species. Those marinas that are in place at least have a foot hold in the dynamic process of land use competition but their potential expansion to meet a growing need is severely constrained by limited space and restrictive controls. These issues dominate the present climate in which marina facilities are planned and developed and are realities which cannot be ignored. The logical response to this challenge is for planners and developers to recognize the 
physical limitations which influence the potential for arowth and to focus attention on devising development strategies whicb better utilize the limited land and water resources available.

The thrust of this project, therefore, is to develop a clear understanding of the function and operation of recreational boating facilities and the incumbent limitations and potential unich dictate their form and capacity. It is our belief that there is a fundamental relationship between the optimum development of a marina site and the natural, political and economic characteristics of its market area. It is also believed that this relationship is common. Furthermore, by devising effective ways with wich to quantify and describe this $I$ lationship, it will be possible to structure the subject of marina planning as a rational process which synthesizes the numerous functional variables that act both externally and internally on marina operation.

A major component of this study is an examination of existing, well established boating facilities with an emphasis on documenting the array of services that are offered to boaters and the public at large. In addition, an effort has been made to determine the passive attributes of the marinas, i.e., those services which are not directly financially productive but, by their very nature, serve to improve the operation and effectiveness of the marina.

Incidental to the survey of marinas is a study of the users and their craft. This aspect of the study is intended as a means of correlating the various costs, both financial and in terms of time, that are born by boat owners, with the level of 
service and other amenities that are offered by the marina as inducements to patronage. This element of the study is an analysis of the value of individual marina characteristics in attracting a proportionate share of the marina market, i.e., a measure of the drawing power of each marina in terms of the physical, loqistic and operational variables inherent in each marina site.

The theoretical arawing power can be interpreted as a general estimate of the potential of the selected marina sites. To evaluate the hypothesis that the present and future success of a marina is dependent on these variables, the study has isolated two existing marinas which represent the range of possible extremes in the evolutionary process of marina development. The two marinas are treated as case studies in which the background of each facility is studied in sufficient detail to produce a chronological profile of the growth and change that has occured at eac $h$ site along with a detailed description of the present level of services and boating activity.

The next section of the study is a review of the technology and other physical elements of marina design that are applicable to the planning of recreational boating facilities. This review is intended as a summary of the various desiqn variables which directly impact the configuration and operational capacity of recreational boating facilities., and serve as criteria for planning decisions. our review of the marina planring literature has shown that the various aspects of marina planning and design criteria has been developed to a 
fairly high level of sophistication. The problem which became apparent is that there is no single source which integrates the most important design requirements into a single design standard for those involved in marina planning.

To demonstrate the application and use of the assembled design criteria, the study returns to the two sites that have been selected as case studies of marina operation and planning. Incorporating the existing conditions and long range goals of these installations, the study now concentrates on several development scenarios for each location resulting in planning solutions of varying cost and operational impact. Each design alternative is based on a different set of assumptions concerning the character of the economic and commercial climate in which the facilities exist. The physical solutions that are presented are intended as responses to the widest possible range of planning problems while, at the same time, offering specific proposals that maximize the spatial efficiency and optimize the commercial potential of each site.

Finally, the design proposals aro critiqued by an objective method of ccmparative evaluatioin in which the relative advantages and disadvantages of each proposal are examined. Using this approach, it is possible to measure the effectiveness of each proposal in terms of achieving the long range goals that have been set for the facility. As a conclusion to this section, it is possible to establish the reasonableness of the planning goals as well as the feasibility of those solutions that are intended to achieve those goals.

The present state of the art of warina planing as 
represented in the literature is organized into three distinct categories. Each group represents a separate level of study that is arranged in a vertical distribution of scales beginning with the vast array of detailed design and component data for equipment and materials, ascending through the functional and economic information base for marina operation and culminating with issues of regional concern such as the interstate mobility of marine service consumers and regional service demand.

one fact that is of considerable interest is that there are strong interdependencies which transcend the stratification of the existing information. For example, regional demand definitely shapes the physical and functional organization of a facility which, in turn, exploits the physical characteristics of structures and equipment. In other words, a comprehensive solution to the problems of growth and changing consumer preferences are multi-faceted and span a wide range of planning scales. Existing development strategies which focus exclusively on only one scale of concern are doomed to failure.

The status quo in marina planning is evidenced by the physical abundance of information which deals with the hardware of marina construction. Every effort has been made to adequately study the hundreds of different forms of equipment. materials and systems that are used in the storage and handing and repair of pleasure craft. It is this equipment that makes a modern marina wat it is. It is important, however, to remember that the sophisticated facilities and the enormous capital required to develop and support a marina are subordinate to consumer denand and exogenous market forces. Certainly. a 
marina that is equipped with the most up to date facilities is a generator of demand. But, by the same token, investment in facilities must be balanced with a clear understanding of the regional potential for marina use as well as the contribution that is made by the facilities in solving the spatial and functional problems unique to the marina site. In this sense, this study deals almost exclusively with the expansion, modernization and improvement of existing marina sites. This planning emphasis is also supported by the theoretical commitment that shore facilities planning for recreational boating facilities is a process which must, by definition, focus on an integration of all levels and scales of interest whether they be hardware or regionally related. 
HISTORICAL PERSPECTIVE

This section of the study deals with the historical backaround of recreational boating and the facilities that have evolyed over time to support this growing industry and pastime.

The word MARINA is a term that was coined in the united States in 1928 by the National Association of Enqine and Boat. ranufacturers. It was defined as "... a boat basin with facilities for berthing, securing and servicing all types of recreational craft." The term is further defined as "... a facility offering services which have come to be a part of modern boating: a place where boatmen may berth, launch, repair, fuel and provision their craft conveniently and be able to have a lot shower and be within easy reach of shops communications and transport" (Encylopedia of Boating, 1973).

obviously, there were no facilities which met this description when yachting was introduced to the world as a recreational activity. Yachting has its roots in the $17 t h$ century when European royalty and gentry used replicas of warships for official transportation. By the 18th century, the sport of yachting appeared with the orqanization of squadrons and small fleets of oleasure craft that wore assembled to participate in cruises and races. The principal difference between the fleots of the 18th century and the private clubs and marinas of today is that there is no evidence that shore or water facilities were made available to the 
memership, other than post sail revelry at the local tavern. Yachtsmen of the period had to rely on the shore support that was provided for the merchant ships and naval vessels, and, as a result, probably bad difficulty competing for anchorage and logistic support.

The popularization of yachting in the latter part of the 19th century and the first half of the 20 th century stimulated construction of wooden pleasure craft in ship building yards up and down the East coast. While boat ouners would moor their boats at other locations, they maintained close contact with the yards for seasonal service and repair. In the early part of the 20th century. the construction of yachts beqan to replace the building of cargo vessels and those yards that remained in the business of building wooden boats began to orient their work toward the maintenance and support of pleasure craft.

Recreational boating continued to grow until world war II but, like all leisure activities, was heavily dependent on the prevailing economy. Por this reason, the largest increase in the popularity of the sport did not occur in this country until after the war. Major changes in the life style of Americans, such as increased leisure time and rising per capita spendable income, lead to a renewed interest in the sport. In addition, the technology of boating went through a period of transition, i.e., from yood to fibreqlass, making the sport more affordable and boats more dependable.

Today, there are over 4,200 marinas and boatyards and 1,300 private yacht clubs in the country. Despite the economic 
situation there is every indication that the demand for this resource will continue to grow. 
REGIONAL PERSPECTIVE

As was mentioned in the introduction, the study of marina development centers around the physical conditions that exist at two operating marina sites. Using actual case study locations enables us to develop proposals and recommendations which have a basic credibility as having been subjected to the test of reality. To this end, it is necessary to put these sites into an econonic and operational perspective which clarifies the forces which generally shape the market for marina facilities.

pirst of all, the two case stuly sites are located in different recreational activity areas. This is to say that. their market and operational juristictions are related to geographically different spatial areas. These areas are in effect the natural resources on which the recreational boating facilities depend as the basic element in the attraction of recreational boaters to a particular region. Should it be found that these forces change from region to region, then it logically follows that it will be necessary to adjust the approach to facility planning in the activity areas to meet different and changing needs.

The activity areas defined in this report are Narragarsett Bay in Rhode Island and Buzzard's Bay in Massachusetts. The specific characteristics of these activity areas which are studied in this report are 1. the present level of marina 
service in each location, 2. the level and nature of existing boating activity and 3 . the existence of any unique phenomenon which might influence the nature of the sport of recreational boating in eithor activity area.

THE PRESENT LEVEL OF MARINA SERVICE

The growth in the popularity of boating in both of the recreational activity areas makes them good examples for the study of recreational boating. Unfortunately. it is somewhat difficult to analyze trends in the demand for facilities since the historic patterns of use at boating facilities can only be determined through surveys and samples of boat owners and their preferences. our review of literature which documented the level of boating activity over the last 16 years indicated that the survay techniques and variations in the categorical definitions for boating facilities has lead to some major inconsistencies in the inventory of pleasure craft and the use of commercial marinas for winter and summer storage. For example, a boating participant has a choice of four different facilities or methods for the storage of his boat. These are private yacht clubs, commercial marinas, boat yards and municipal facilities. For the purposes of this study, those boats that are kept at marinas and boat yards are of particular interest in that our planning recomendations are specifically targeted to these facilities.

As of December 1973, there were 14,383 recreational boats registered in the State of Rhode Island (Rorholm, 1976). While 
this statistic may sound impressive, it should be made clear that not all registered boats are kept at commercial recreational boating facilities, that is boat yards and marinas. It has been estimated, however, that approximately 38\% of all boats registered in Rhode Island spend the summer boating season in thode Island marinas and yards (Rorholu, 1963). During the summer boating season of 1962, there were 2,980 boats $k$ pt at marinas and yards in Narragansett Ba $y$ (Rortoll. 1963). During tho boating season of 1972, this number had risen to 6.026 , or a $70 \%$ increase in the use of yards and marinas in the region (Kelly \& Rorholm, 1974). If $38 \%$ of the registered craft were kept in the commercial facilities then 5,465 boats of the 6,026 total were registered to Rhode Islanders, indicating that the majority of pleasure craft kept in Rhode Island marinas were registered to residents of the state.

A later inventory conducted in 1975 has shown that there were a total of 7,835 pleasure craft stored at docks, slips, and moorings during the 1975 boating season in Narragansett Bay (Urban Design Group, 1975). This figure represents the total number of craft stored at all facilities: public, private and commercial. When compared with the census of pleasure boats conducted in 1972 (Kelly \& Rorholm, 1974), it can be seen that marinas and boat yards attract the vast majority of pleasure boats during the boating season.

The most revealing survey of marina facilities was conducted in 1977 as a component of the Areawide water Quality Management plan (Johns et. al., 1978). On the 29th and 30 th of 
September of that year an aerial survey was made of all boating facilities in Narragansett Bay. From this survey it was possible to inventory the capacity and services offered at each installation. This survey determined that there were a total of 9.519 boats at all shore installations which represents a $21 \%$ increase over the number enumerated in the 1975 survey. Again, caution is advised in the interpretation of these data since the aerial survey methodology. while reasonably reliable in auditing the presence of pleasure craft, could have easily overlooked certain facilities and operating equipment.

Beyond the tabulations of boat numbers, the survey did observe a number of interesting factors concering the availability of facilities and services at boat yards and mariras which are as follows:

"... of the facilities surveyed in Rhode Island, approximately two thirds do not have any type of boat hauling capability (marine railway, crane or travelift)..."

"... about 50\% of all facilities have one or more boat launching ramps..."

"...there appeared to be much less potontial for land, as opposed to water expansion of marina facilities. Thirty-three percent of the facilities had moderate to hiqh potential for land expansion while $66 \%$ of these facilities had moderate to high potential for water expansion..." 
The use of marinas and yards in Narragansett Bay for inter storage has traditionally been less than the level of summer activity. The survey of marinas conducted in 1972 found that 69 facilities provided summer berths and moorings. At the same time, the survey noted, only 60 firms offered winter storage for 4.139 boats, $75 \%$ of which were kept outside (Kelly \& Borholm, 1974). While this information is dated, there was evidence that the use of indoor winter storage was limited by the availability of facilities and that outdoor winter storage did not, on a regional basis, meet the estimated capacity of the commercial yards.

In an attempt to corroborate the information collectod during the aerial survey process, this study has refered to a common source of boatinq information. The Boating almanac (Geis, 1979), a publication which inventories all boating facilities and reports on the level and type of services that are offered. From the list of boating facilities a selected group of 66 facilities have been chosen as having met the basic criteria as a marina or boat yard. The Boating Almanac vas also consulted for similar information for the second boating activity area, Buzzard's Bay, and it has been possihle to make some direct comparisons between the two regions and their boating facilities.

$$
\text { First of all, there are } 67 \text { boating facilities in }
$$
Narragansett Bay as opposed to 35 facilities inventoried in Buzzard's Bay (Figure I1). From the analysis it can be seen that the Buzzard's Bay facilities are marginally better equiped from the point of view of boat hauling capability. 
Approximately $60 \%$ of the facilities in Buzzard's Bay have this capability, while $55 \%$ of the facilities in Narragansett Bay are equiped to haul boats. A principal difference that was observed was in conncction with the size of the facilities and the methods of winter and sumer storage. For example, the marinas in Narragansett Bay had an average slip berthing capacity of 92 boats, and the Buzzard's Bay marinas had an average slip bertbing capacity of 43. On the other band, the Buzzard's Bay facilities had an average of 46 moorings each while the average for the Narragansett Bay facilities was 10. This suggests a greater popularity of moorings in Buzzard's Bay and a similar preference for slips in Narragansett Bay. The average overall size of the marinas are simila,, however, i.e., 102 boat capacity in Narragansett Bay and 86 boats in Buzzard's Bay (Figure I 1).

As for winter storage, $54 \%$ of the Buzzard's Bay facilities offer indoor storage wrize orly $27 \%$ offer this service in Narragansett Bay. on the other hand, a comparison of the percentages of facilities which offer no winter storage indicates a different trend. The most recent data indicates that fewer Buzzard's Bay facilities can accommodate boats over the winter period. $60 \%$ of the Buzzard's Bay installations offer some form of winter storage while more than $70 \%$ offer this service in Narragansett Bay.

To further compare the level of boating service provided on a regional hasis, 11 services that are comonly provided by recreational boating facilities have been identified with the Erequency of their occurance recorded and correlated against 
the size of the boating facilties. The services which have been documented are: fuel, dockside electricity, repair capability, marine or harduare store, toilet facilities, ice, shovers, restaurant, laundry, irdoor and outdoor storage. It was found that the boating installations in the two regions are relatively equivalent in terms of the number of services offered. on average, the marinas in both boating regions have 6 of 11 services. Upon closer inspection it can be seen that the Narragansett Bay facilities are slightly better equipped in terms of the percentage of facilities offering the selected services (Figure I1). It yas also found that there is only a slight positive correlation between the capacity of the marinas and the level of services offered. In other words, the larger facilities with the groatest capacity usually offer the widest assortment of on-shore services. There are a sufficient number of exceptions to this trend, however, to make one question its validity. One possible explanation could be that the on-shore services are not always developed for the water born customer. e.g., a restaurant usually depends on a much broader market for its survival. Secondly, the number of slips and moorings is not necessarily a good indicator of the level of transient activity in the region. A small marina with a larqe transient turnover can ofton justify the capital investment for a range of ancillary services that is normally associated with larger installations. The graphs on the following pages illustrate the somewhat random association between marina size and the level of on-store services. (Figures I2 \& I3). 
THE LEVEL AND NATURE OP EXISTING BOATING ACTIVITY

The principal variables that are used as indicators of the level of boating activity in the two boating regions, are the number of boats, their size, and power characteristics. The previous section, in dealind with the capacity of boating facilities as evidence of their service capability. reported the results of several surveys which documented the volume of boating activity at marinas as a measure of pleasure boats berthed. In absolute numbers, the level of boating activity in Narragansett Bay would appear to be much higher than that of Buzzard's Bay yet the average marina size dose not substantiate the conclusion. There are twice as many boating facilities in Narragansett Bay and this fact alone should imply the regional dominance of the area as a focal point for boating activity.

There are two studies that were consulted in this report which provide some insight into the recent trends in boating activity. The first study. which is the basis for trend development, documented boting in Narragansett Bay during the 1972 boating season (Kelly \& Rorholm, 1974). Through a sample of 69 selected boating facilities, it was observed that the distribution of the mode of propulsion was $21 \%$ sail and $72 \%$ pover. The Raytheon study, which was cited in the previous section (Johns, et. al., 1978), was particularly effective in locating the recreational boating fleet in Narragansett Bay and in identifying the size and power characteristics of those vessels. The survey documented that $67 \%$ of all pleasure craft were power and $33 \%$ were sail. Each of these studies reported 
the distribution of boats by length but these statistics are somewhat difficult to compare since different breaking points of boat size were used. This notwithstanding, it is still possible to recognize that there is a definite trend emerqina in the user preference for smaller boats. This observation has been corroborated by the operators of the caso study marinas. The frequency distributions which follow, graphically illustrate the general reduction in boat length and shift from power to sail as discussed (Figure I4).

UNIQUE REGIONAL PHENOMENA

The boating environments of Narragansett and Buzzard's Bays have a number of geographic and cultural features which influence the quality and character of boating service offered at their warinas and boatyards. The area of Narragansett Bay and Block Island sound, hesides being noted for its competetive sailing and sport fishing, is endowed with a number of attractions, such as Newport, which draw cruising yachtsmen from all of the eastern seaboard. By the same token, the upper part of Buzzard's Bay is contiquous to the southern entrance of the cape cod Canal, which is the most direct route to Boston Harbor and the Maine coast. Several informal surveys have noted that the nature of the canal traftic influences the 
transient nature of the marina operations in its vicinity. For example, power boats are said to be preferred in this area since they are more adept at negotiating the strong currents of the canal. This point could certainly be disputed yet the fact remains that there is a higher relative percentage of power boats in Opper Buzzard's Bay.

The evidence of the energy situation is all around us. It is certainly important to report our findings concerning the response of the boating industry to the price and availability ot fuel. While we are not spokesmen for the industry, we believe that the results of our conversations with marina operators are representative of the common problem of fuel shortages and cost. The marina operators indicated that the patterns of boating activity are beginning to reflect some lack of confinence in the fuel supply system. First of all, it was noted that tho consumption of fuel has not appreciably decreased over the last two years. The yachtsmen, however, are apparently adjusting thoir boating habits by reducing the travel distance of their cruises. In other vords, they are confining their cruising to local waters. If this contition persists, then it is reasonable to expect that the demand for transient facilities may be less than it has been in the past.

\section{CONCLUSION}

The most important discovery that was made in the $r \in v i e w$ of regional boating activity, is the very perceptable trend toward smaller boats, particularly among those in the inboard power 
class. If we can assume that there is a reasonable likelihood that this trend will continue, then boating facilities will have to respond in such ways so as to accomodate the changing needs of the boating market. Actually. this could present a nel range of opportunities for marina operators to meet the unabated demand for facilities. If the recreational fleet is indeed growing in numbors but decreasing in size, then boating facilities have a greater chance to increase their capacity within the shrinking or libited space.

our perception of this situation is that many facilities on Narragansett Bay have limited growth potential when the requirements of larger pleasure craft are used as the criteria. If those criteria aro moderated by the introduction of less demanding vessels then additional water and land area will become available for productive use.

The level or frequency at which various services were observed at the marinas and yards indicates a clear trend in the way in which facilities have evolved in the activity areas. First, the Narragansett Bay marinas are definitely larger by comparison and are slightly better eguipoed in terms of essential services such as provision of dockside electricity, repair capability, head, etc., as well as the preferred functions such as marine supplies and food service. There is also a significant difference in the percentage of yards which offer winter storage either inside or outside. This revelation leads us to believe that the Massachusetts boaters have a higher incidence of wintering their boats at some location other than whore tho boats are berthed for the sumer. The 
probable cause and effect relationship of this situation is not known but it may be attributable to an endemic lack of storage space in Buzzard's Bay or a market preference on the part of the boat owners to locate their boats in private storage areas or commercial yards that are more convenient to their place of residence.

The final conclusion is that marinas, by their very nature must occupy space within the coastal zone where there is a high degree of access both by land and by water. This fact makes these locations the logical meeting place for land and water recreation, a concept that a number of marinas have exploited to great advantage. The attraction of water, particularly water in combiration with boats, has a unique drawing power which can be used to a ugment the level of consumer interest that is needed to make most comercial enterprizes feasible. Restaurants, for example, rejuire a substantial consumer market to make business practical. In most cases, the level of business generated by the users of a marina alone is insufficient to warrent this type of operation.

There are also effects of agglomeration in which certain commercial functions can serve to induce additional boating business and the ultimate demand that this produces for additional boat oriented service.

The potential, then, for marinas to serve a broader public is clear. Furthermore, the need for marinas to undertake to include the non-boaters as part of their clientel is apparent when one considers the scarcity of recreational opportunities of this type in the urbanizing waterfront. 
Figure II

ACTIVITY AREA COMPARISON

SERVICES OFFERED

\begin{tabular}{|c|c|c|c|c|}
\hline $\begin{array}{l}\text { Service } \\
\text { Offered }\end{array}$ & \multicolumn{2}{|c|}{$\begin{array}{c}\text { Narragansett } \\
\text { Bay }\end{array}$} & Buzzards & Bay \\
\hline & $\%$ & 非 & $\%$ & 非 \\
\hline \multicolumn{5}{|l|}{ Boat Handling } \\
\hline Capability & 55 & 37 & 60 & 21 \\
\hline Inside Storage & 27 & 18 & 54 & 19 \\
\hline Outside Storage & 70 & 47 & 60 & 27 \\
\hline Fue 1 & 63 & 42 & 77 & 27 \\
\hline Electricity & 85 & 57 & 60 & 21 \\
\hline Repairs & 70 & 47 & 63 & 22 \\
\hline \multicolumn{5}{|l|}{ Marine Store } \\
\hline Hardware & 69 & 46 & 60 & 21 \\
\hline Rest Rooms & 81 & 54 & 77 & 27 \\
\hline Ice & 66 & 44 & 66 & 23 \\
\hline Showers & 33 & 22 & 34 & 12 \\
\hline \multicolumn{5}{|l|}{ Restaurant } \\
\hline Snack Bar & 24 & 16 & 14 & 5 \\
\hline Laundry & 4 & 3 & 9 & 3 \\
\hline
\end{tabular}

CAPACITIES

\begin{tabular}{|c|c|c|c|c|}
\hline & \multicolumn{2}{|c|}{$\begin{array}{c}\text { Narragansett } \\
\text { Bay }\end{array}$} & \multicolumn{2}{|c|}{ Buzzards Bay } \\
\hline & Avg. & 非 & Avg. & 非 \\
\hline Facilities & & 67 & & 35 \\
\hline Slips & 92 & 6169 & 44 & 1536 \\
\hline Moorings & 10 & 638 & 43 & 1497 \\
\hline Tota1 Capacity & 102 & 6807 & 86 & 3033 \\
\hline
\end{tabular}




\section{F IGURE I2}

Boats vs. 非 of Services

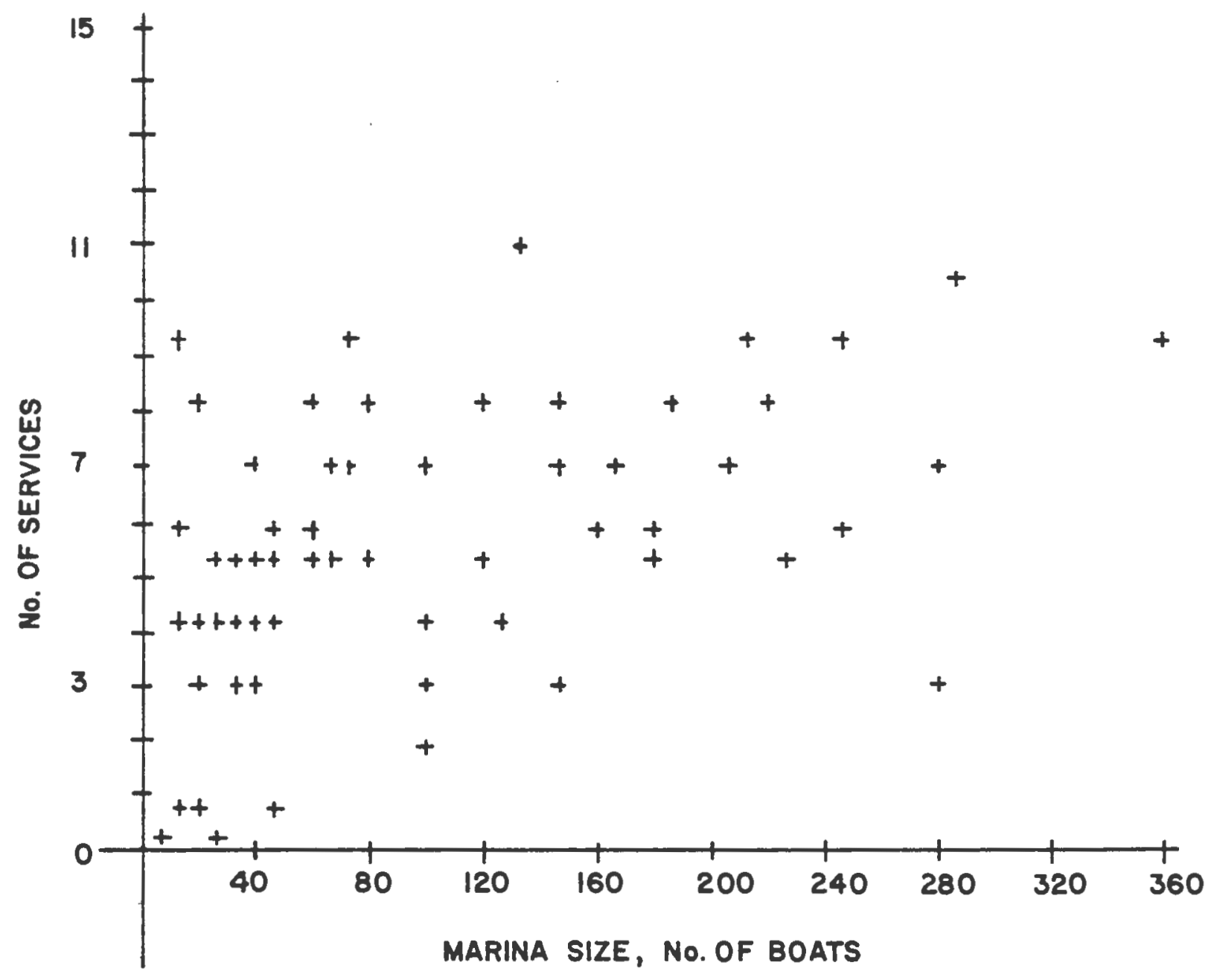

NARRAGANSETT BAY

Data Source: Boating Almanac, 1979 
Eigure I3

Boats vs. 非 of Services

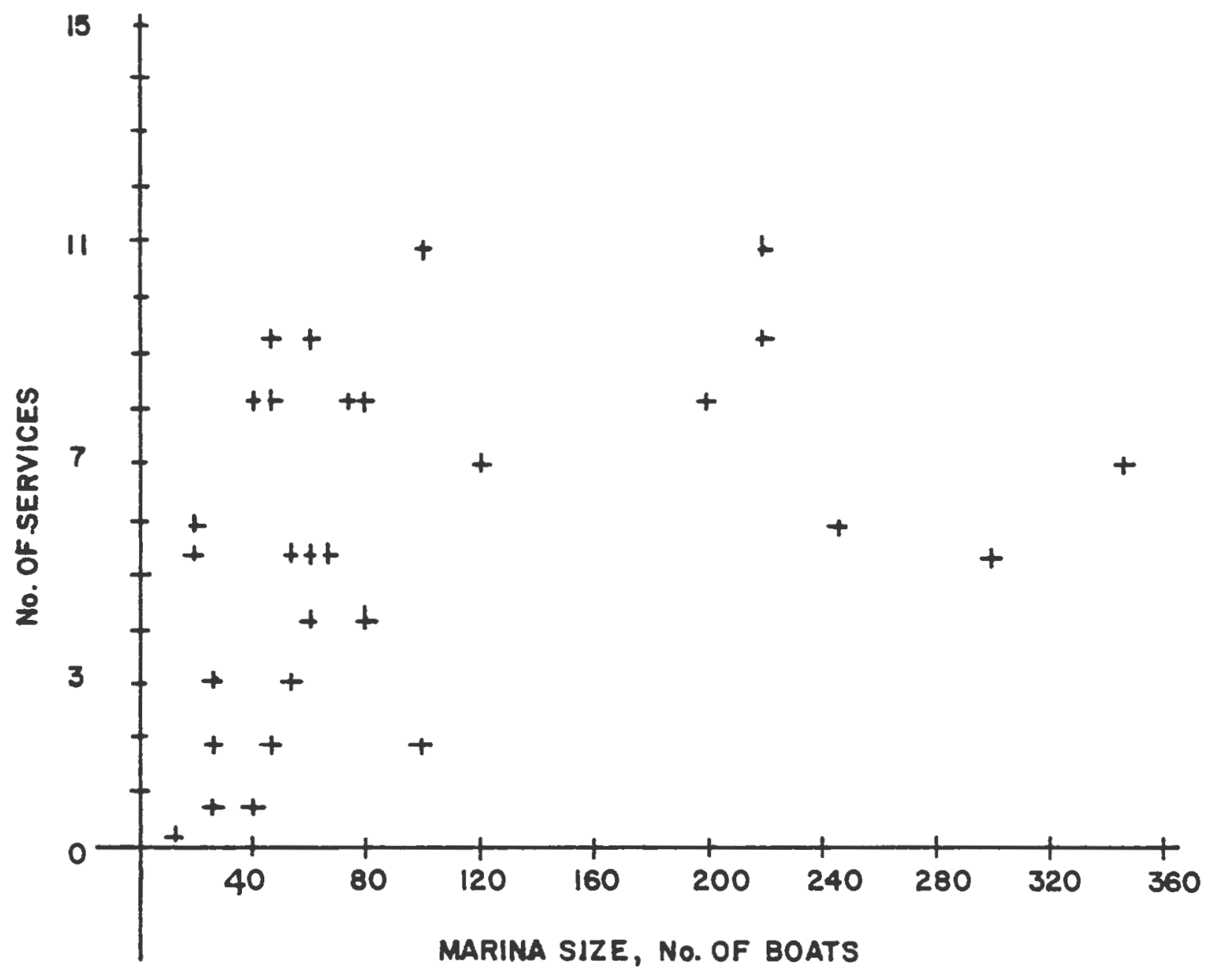

BUZZARDS BAY

Data Source: Boating Almanac, 1979 


\section{Figure I4}

NARILAGANSEITT BAY

DIST:? STIION BY LENGTH

\begin{tabular}{|c|c|c|c|c|c|c|c|c|}
\hline & \multicolumn{2}{|c|}{$<16^{\prime}$} & \multirow{2}{*}{$\begin{array}{r}16^{\prime} \\
\text { Power }\end{array}$} & \multirow{2}{*}{$\begin{array}{r}-25^{\prime} \\
\text { Sail }\end{array}$} & \multirow{2}{*}{$\begin{array}{r}26^{\prime} \\
\text { Power }\end{array}$} & \multirow{2}{*}{$\begin{array}{r}-39^{\prime} \\
\operatorname{Sat} 1 \\
\end{array}$} & \multicolumn{2}{|c|}{$>40^{\prime}$} \\
\hline & Power $r$ & Sail & & & & & Power & Sail \\
\hline \multirow[t]{3}{*}{1972} & 4.4 & 1.0 & 42.4 & 10.4 & 25.1 & 9.2 & 5.7 & 1.5 \\
\hline & \multicolumn{2}{|c|}{$<18^{\prime}$} & $19^{\prime}$ & $-25^{\prime}$ & $26^{\prime}$ & $-45^{\prime}$ & \multicolumn{2}{|c|}{$>45^{\prime}$} \\
\hline & Power & Sail & Power & Sail & Power & Sail & Power & Sail \\
\hline 1977 & 15.2 & 6.1 & 25.4 & 11.2 & 16.7 & 10.4 & 0.6 & 0.3 \\
\hline
\end{tabular}

Source: Kelly \& Rorholm, 1974

Johns, et. a1., 1978 


\section{CASE STIDY MARINA PROFILES}

This section contains basic profiles of the case study marinas: Stone Cove Marina in South Kingstown, Rhode Island, and Kingman Marine in Cataumot, Massachusetts. These tro marinas are very different in most respects, and the contrast between them is useful to illustrate different types of management and facilities. Please note that it is not the intent of this analysis to evaluate either marina as being better or worse in some respect than the other. Given the constraints of owrership and location situations, absolute comparisons ard comparitive value jungements are not especially useful. Rather, each marina, or comparisons between them, vill be used to illustrate various options in land use, water use, and marina operations in general. These profiles provide the basis for the corparisons.

\section{STONE COVE MARINA}

Stone Cove Marina is located in south kingstown, Rhode Island, at the upper (northern) end of point Judith Pond. Figure P1 shows the general study area with each case study area indicated. Pigure P2 shows the Point Judith Pond area, and Figure P3 shows thr layout of stone cove Marina. The pond is a long, shallow body of salt water with estuarine 
characteristics. The mean range of tide at the upper end is 3.5 feet. Saugatucket River flows into the pond $1 / 4 \mathrm{mile}$ west of Stone Cove Marina. The pond is approximately 4 miles long in a north to south direction, and averages 1 mile in width. Access to the ocean is provided at the southern end through the Port of Galilee breachway. The port of Galilee is a busy commercial port, with the largest fishing fleot and second highest value of catch in Rhode Island (Murphy, 1979). The land surrounding the southern part of the pond is fairly densely developed with single family housing. A large part of these are summer and retirement homes on small lots. There are a total of 13 marinas on the pond, with approximately 980 slips and 15 moorings (Boating Alnanac, 1979). The larqest marina is the Rhode Island State Fier at Galilee, witb 280 slips. Stone Cove is second in size with 145 slips. The remaining 11 marinas on the pond are smaller, with an average of 49 slips Each. Also on the pond are the Point Judith Yacht $\mathrm{Club}$, the Iniversity of thode Island sailing club, and two public launching ramps. There is a 14 foot deep channel, maintained by the Army corps of engineers, at the southern part of the pond for the fishing vessels, and a 7 foot doep channel to the State pier. The channel in the remainder of the pond has between four and six feet of water at low tide. This effectively limits the draft and overall size of the majority of hoats found in most of the pond. Thus the largest boats to be found at stone cove Marina are in the forty-foot class, and most are somewhat smaller. In addition to the depth limitation, stone cove is somewhat out of the way of the 
mainstream of boating traffic cruising batween Long Island Sound and New England waters. The result is that almost all of the business is from seasonal customers: there is virtually no transient traffic.

Access from land is much more convenient. Route one, the old Atlantic coast highway. is the major thoroughfare for southern Rhode Island, and actually borders stono cove Marina on the north. This stretch of the highway is 4 lane, limited access, with an intersection adjacent to the marina property. Access by automobile is direct and simple.

OWNE RSHIP and EMPLOYMENT - In contrast to most marinas in tho New rngland area, the owners of stone Cove Marina, Mr. and Mrs. Steven wood, do not own the land that the business is situated on. The waterfiont parcel of land bounded by Route one on the north. stone cove proper on the east, and the Saugatucket piver on the west is owned by the Town of south Kingstown. There is a history of marina activity on the present stone cove sito. A large scale aerial photograph of the area, taken in 1948, shows a boatyard/marina with three long docks and a collection of buildings. one of the buildings has "Hansons Boatyard" painted on top. The stone cove Marina site takes up about $25 \%$ of the town-owned parcel. In the 1948 photograph, the rest of the parcel is vacant, currently, there are three marinas, including stone cove, on this parcel. Ram Point Marina, with 60 slips and 15 moorings, is at the western end of the parcel. Iong Johns Marina, with 37 slips and $a$ popular restaurant, is situated between Ram point and stone 
Cove. Two town launching ramps, and parking lots for both, the Point Judith Yacht Club, and the URI sailing club, are also on the parcel. The only vacant waterfront land left is between Stone cove and Long Johns marinas, and a piece on the Saugatucket River between Ram point Marina and poute 1.

Currently, Stone Cove Marina has a ten year lease on its portion of the parcel. This lease was negotiatel in 1971 when the Hoods bought the business. The town has indicated no interest to sell, but negotiations for a fiftern-year lease to begin subsequent to tho existing lease are currently underway. The existing lease expires in 1981, and until new terms have been agreed upon the owners of the marina are understandably reluctant to invest in certain improvements to their business facilities. The parcel abutting the marina to the west is partially vacant, and contains one of the launching ramps which is too steep for ease of launching and, consequentially, is not used very much. Stone cove yould like to expand their operation into this property: this is part of the ongoing negotiations with the town.

The entire parcel owned by the town is zoned as a "public zoning district", which, according to the zoning regulations. is primarily intended for public buildings and facilities. The comercial uses of the marinas are permitted by lease agreement, and there are no set regulations. Any changes within the parcel must be negotiated with the town on a case-by-case basis. If the town were to decide to sell to the marinas, a zoning change, consistent with the existing use and master plan, would be necessary. 
Relationships with the town are through the town manager and the town Haterfront planning Committee. The relationship could be characterized as cordial.

Total employment at Stone Cove is relatively small with 6 full time and 2 to 4 part time employees. Mr. and Mrs. Wood work part time, and there are two dock boys during the summer season. Steve wood, Jr. works full time as manager of the yard. Four mechanics and a sales/office worker make up the rest of the staff. The structure seens to work quite informally, with people pitching in where and as needed.

FACIIITIES - Stone Cove Marina occupies approximately 3.7 acres of water and 3.1 acres of land. The land to the west has 0.73 acres for potential expansion, and the parking area across the road measures 0.87 acres. There are two buildings on the property: an outbuilding containing toilets and a shower, and a main building housing the shops, office, and sales area. outboard motors are stored and serviced indoors, but there is no indoor winter storage for boats. The main building is a long, one story wooden shed structure, built on pilings. The condition of this facility has been improved over the last few years, but it needs to be replaced. Discussions about possible replacement are part of the negotiations ongoing with the town. Both buildings have recently been hooked up to new town sewers. Most of the remaining land area of the marina is a level 
dirt/gravel parking and boat storage area. In the water there are 145 slips and no moorings, distributed as shown in Fiqure P4a.

A "single" slip has a finger pier on each side of a boat, i.e. one boat per slip. A "double" slip has two boats per slip, with a finger pier on one side of the boat only. Sinale slips are slightly more expensive. There are moorings in the pond near the marina, but these are administered by the town at present. hen the present owner took over stone cove he had the option of using these moorings but declined them, as he felt that they would be an additional burden to his improvement program. There are ro jetties or groins protecting stone cove, as the area is naturally protected by the configuration of the pond. The only real physical hazard is storm surge, which has been estimated at a possible 12 feet on a 100 year frequercy (HUD - FIA, 1976). The area has been classified as being in flood zono 19 . Even greater surge flooding is possible in the event of a hurricane. There are no problems with current, hut concomitantly there is a fairly slow flushing rate in the end of the cove, where surface debris tends to collect. The edge of the marina yard has been filled to level it off, and the shoreline is protected from routine erosion by riprap bulkheading along its length. The docks are predominantly wooden, in standard sections, with styrofoam flotation and held in place by wooden pilings. There are a few fiberglass docks left from the previous owner, but most of these have been phased out as they wore out. Most of the docks have been replaced or repaired within the past $f \in w$ years, and they are 
all in good condition. The docks and some of the pilings are removed at $t h e$ end of the season with a small derrick and replaced in the sprina. Bubblers vere tried for several years, but proved costly in terms of maintainence, and the docks were damaged by floes from the spring ice breakup on the pond. Water and electricity are available on all docks, witb 20 amp service standard and 30 amp hookups available for the larger boats. For nighttime use there are several large area-wide floodlamps, and there is footlighting on some of the docks.

security and medical emergencies are taken care of hy proximity to the town police department and the area hospital, both of which are immediately on the other side of route 1. There are two fire hydrants, one at either end of the property, and 14 fire extinguishers on the property.

There is a fairly complete array of services for boats, including sales of new Mako boats and Mercury outboard motors, sales of used boats, parts, service including all types of motors and mechanical equipment, fishing tackle and lures, and outdoor storage. Boats are launched and hanled usinq two trailers on a gravel ramp, and a 15 ton crane with a truck body. The crane lifts the boats on and off the trailers, and is also used for lifting some boats directly in and out of the water. outdoor storage is on standard blocks and jacks.

The marina is a dealer for Texaco fuels. The gas dock is located in the deepest water, and at the point of easiest access to the pond. Tho tanks and pumps are at the edge of the yard, near ths pier which has the gas dock. Retween the Rhode Island state Energy office and Texaco, Stone cove was able to 
obtain sufficient fuel durinq the 1979 season. The allocations for 1977 and 1978 aze shown in Figure P4b. A1+hough 1979 figures were not available, indications vere that 1979 was about the same as 1978. Since stone cove sells gas to commercial fisnermen and to the Coast Guard Auxiliary, they were able to keep their allocation from being severlv cut during the general cutbacks of the 1979 season.

CUSTOMERS and THEIR BOATS - Figure P5 shows the distribution of boat owners from the 1979 summer season. Stone Cove Marina is represented by the triangular symbol. Each dot on the map represents the town center where a stone cove customer lives. Larger dots are used in towns where more than one customer lives. As can be seen by immediate inspection, a large part of the customer population lives within Rhode Island - over 75\%. Four towns in Rhode Island account for over 45\% of the boat owners: South Kingstown, Narragansett, North Kingstown, and Providence. The circles represent radii of 10 . 25. 50, and 75 statute miles. The percent breakdown of customers living within these is shown in Figure P6. The towns, with corresponding numbers of owners, are listed in Figure P7. Orly about one-fifth of the customers of the marina live more than fifty miles avay (as the sST flies). The average travel times along major routes in $\mathrm{New}$ England are shown in Pigure P8, comparing the owner distribution with the average travel time indicates that most of the owners (about four-fifths) live within 50 minutes of the marina.

Investigation of the sizes of boats corresponds $w i+h$ the 
general proximity of customers. Figure p9 shows the distribution of boat sizes during the summer 1979 season - over 70\% are 25 feet in length or smaller. In addition, there were only 9 sailboats in a 11, a ratio of about $7 \%$. So it can be seen that a prevailing type of use at the marina is day use only. in small and medium sized powerboats capable of reaching the Galilee breachway and thus Block Island sound in a relatively short time.

BATES - Basic rates for the 1980 summer season are $\$ 15$ per foot for a double slip, and $\$ 16$ per foot for a single slip. Wirter storage has a basic charge of $\$ 9$ per foot to haul. store, and launch. Extra services, and their rates, are shown in Figure P10a, P10b. 


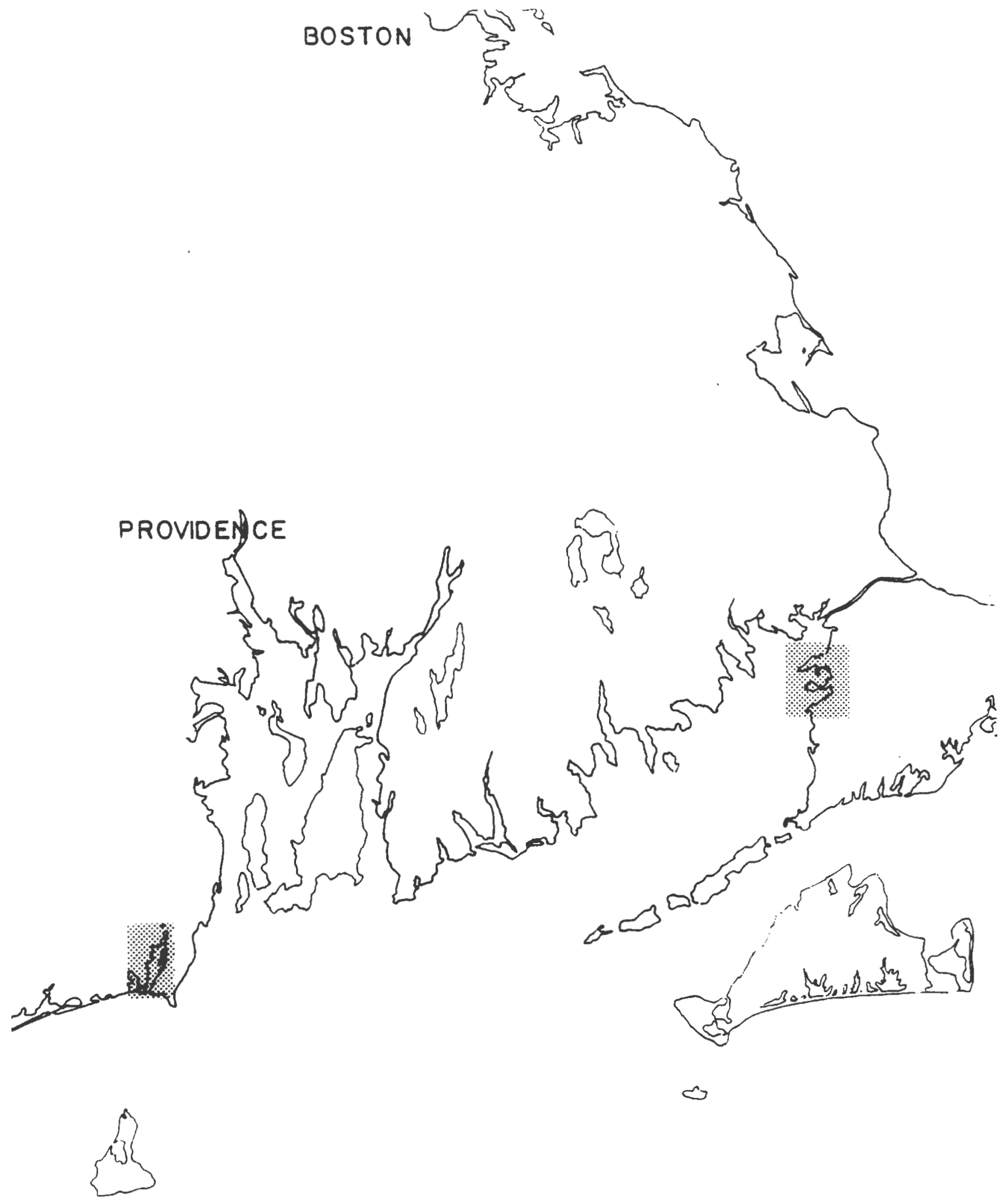

MARINA CASE STUDY SITES AND THEIR LOCALES STUDY 
Figure P2

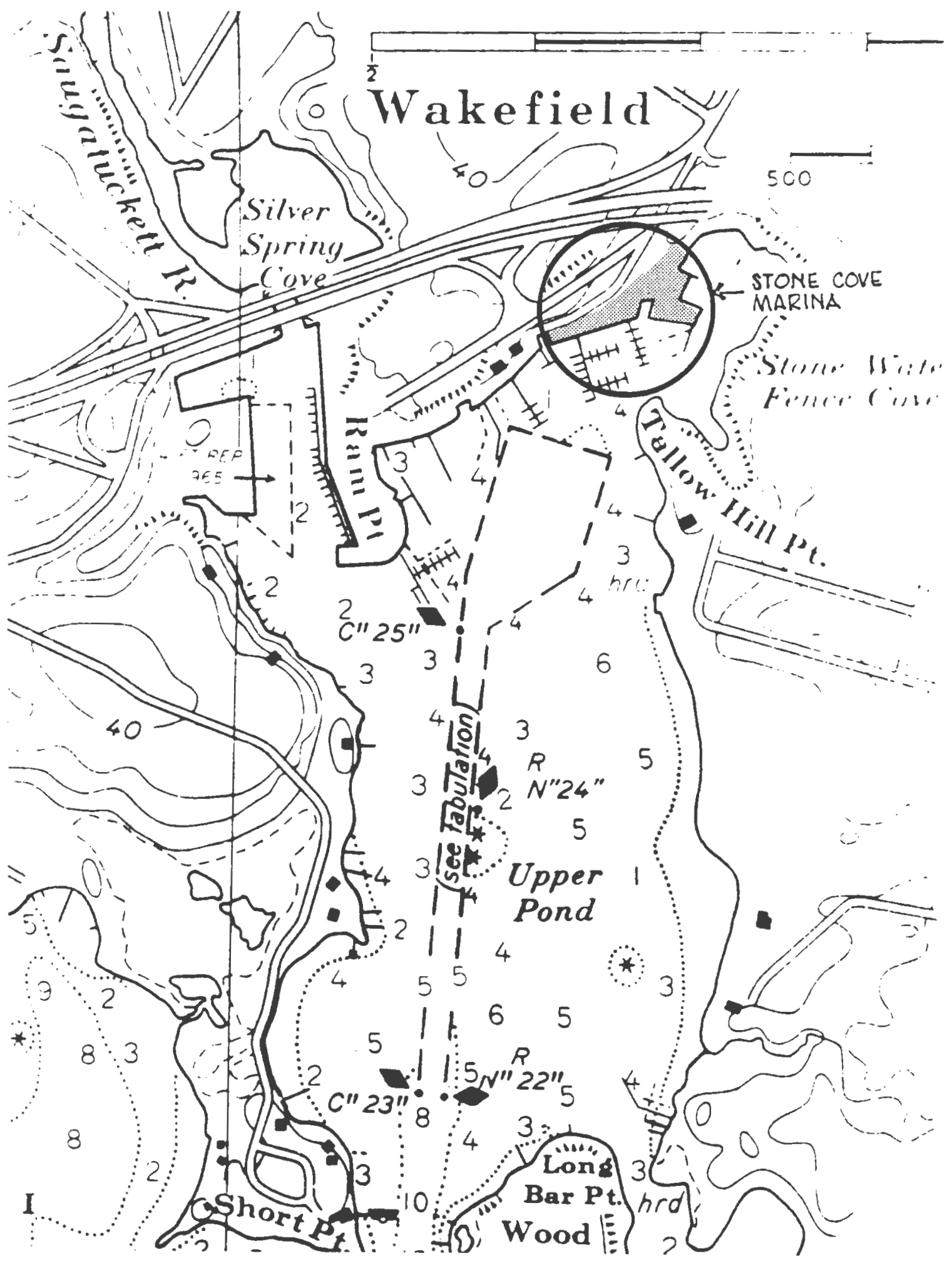




\section{Figure P3}

\section{STONE COIE MARINA - EXISILNO CONDITIONS}

1. Slips area

2. Fuel dock

3. Hauling'launching ramp area

$\rightarrow$. Yard working area winter scorage

5. Sales, administration

6. Service, outboard notor storage

7. Rest rooms, shower building

8. Dutdoor equipment storage

9. Public launching ramp

10. Vacant waterfront land

11. Public parking

12. Marina parking

13. Adjacent marina
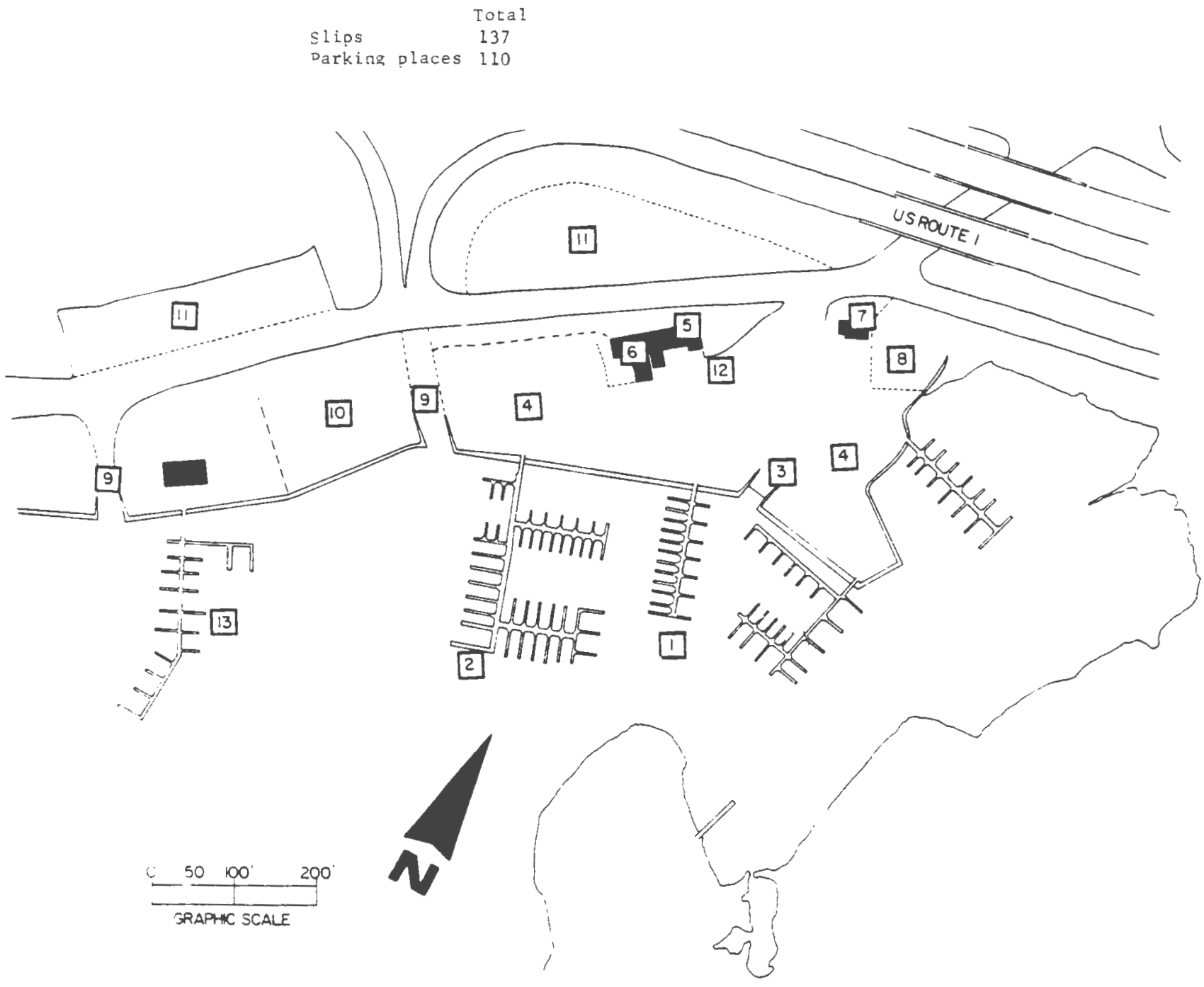


\section{$\underline{\text { Figure } \mathrm{P} 4 \mathrm{~A}}$}

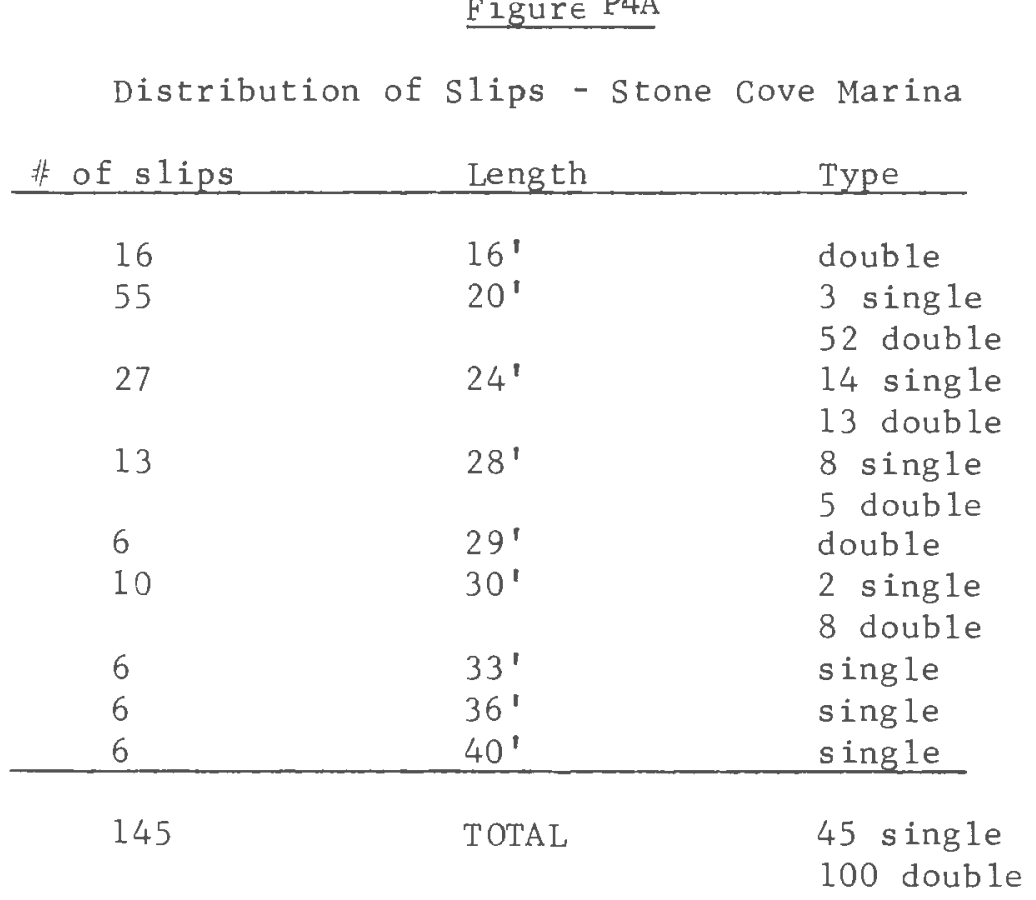

Figure P4B

Gasoline Allocations - Stone Cove Marina

\begin{tabular}{lcc} 
Month & 1977 & 1978 \\
\hline $\begin{array}{l}\text { January } \\
\text { February }\end{array}$ & & 1000 gallons \\
March & & \\
April & 3450 gallons & 3000 gallons \\
May & & \\
June & 3400 gallons & 2300 gallons \\
July & 3400 gallons & 7000 gallons \\
August & 6400 gallons & 4850 gallons \\
September & 3000 gallons & 5100 gallons \\
October & & \\
November & 1000 gallons \\
December & & \\
TOTAL & 17,950 gallons 23,250 gallons
\end{tabular}




\section{Figure P5}

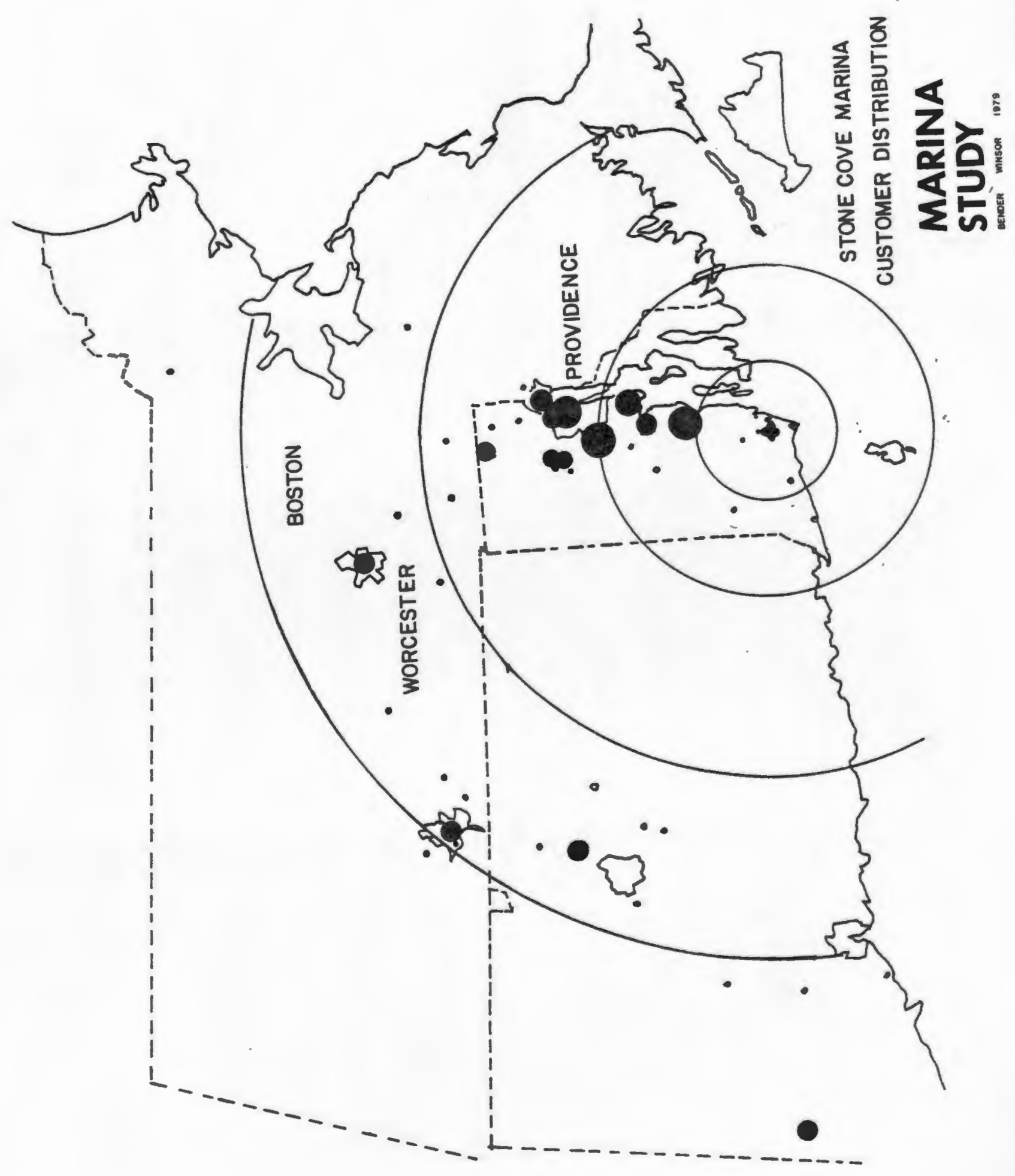




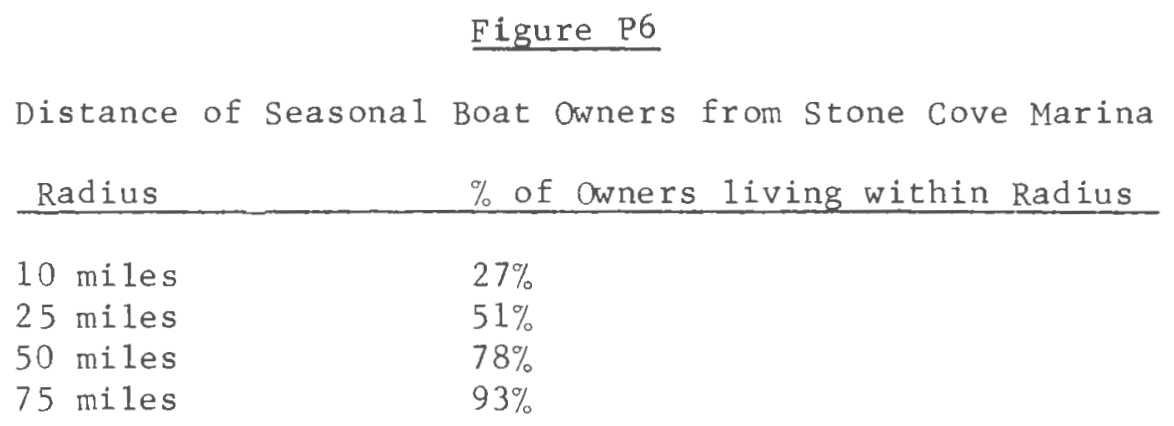

Figure P7

Towns with more than one customer - Stone Cove Marina

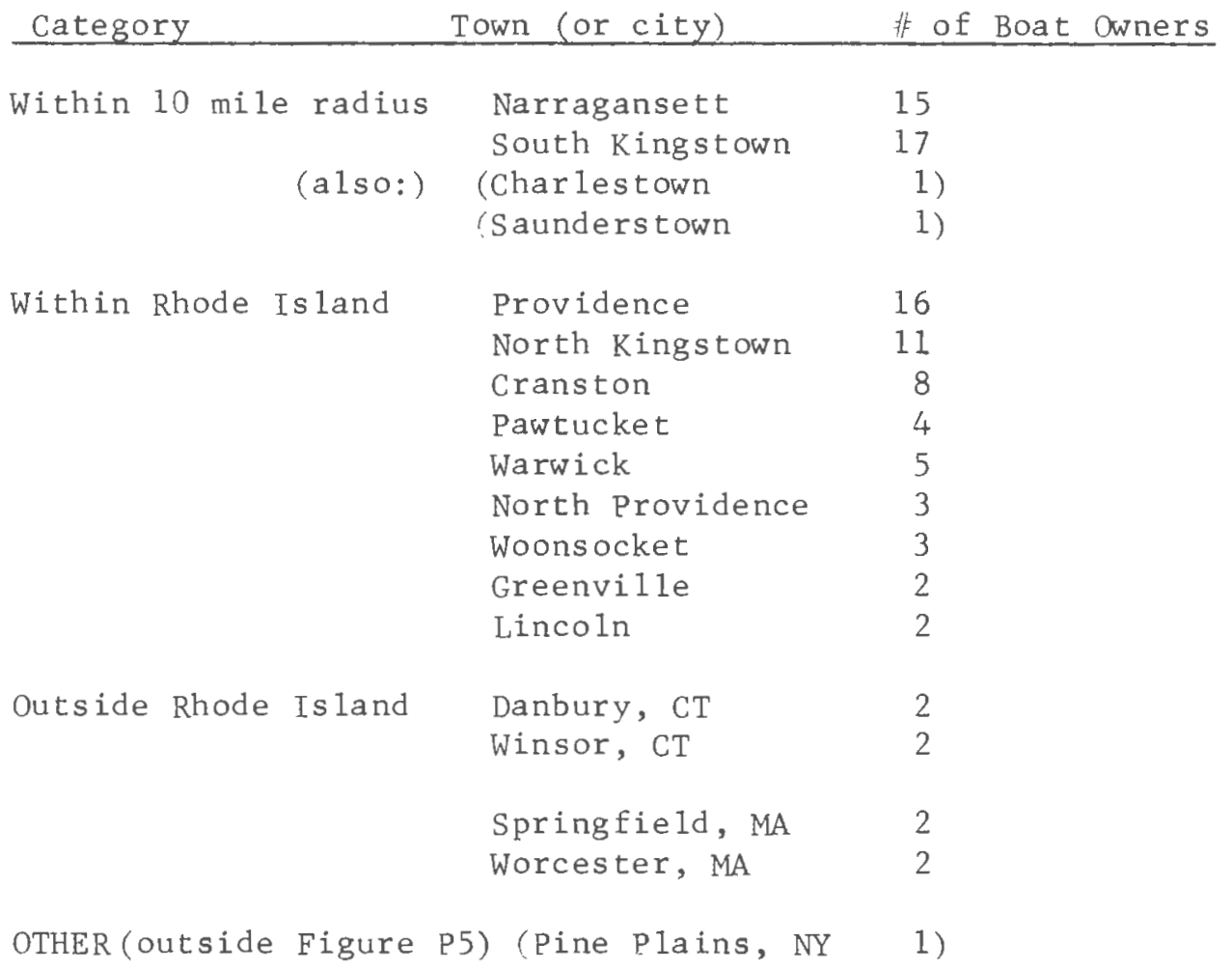




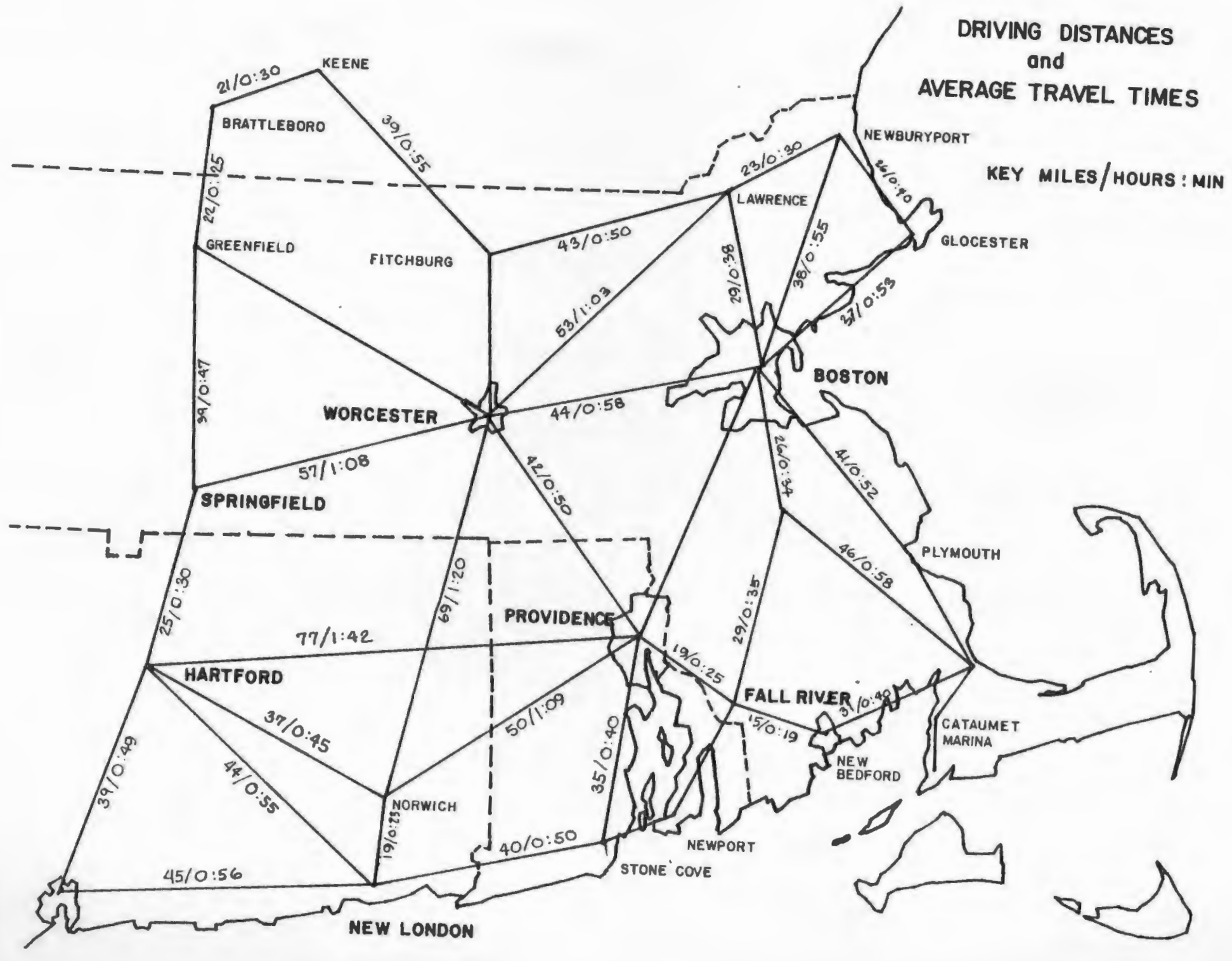


DISTRIBUTION

OF BOATS

BY LENGTH

STONE COVE MARINA

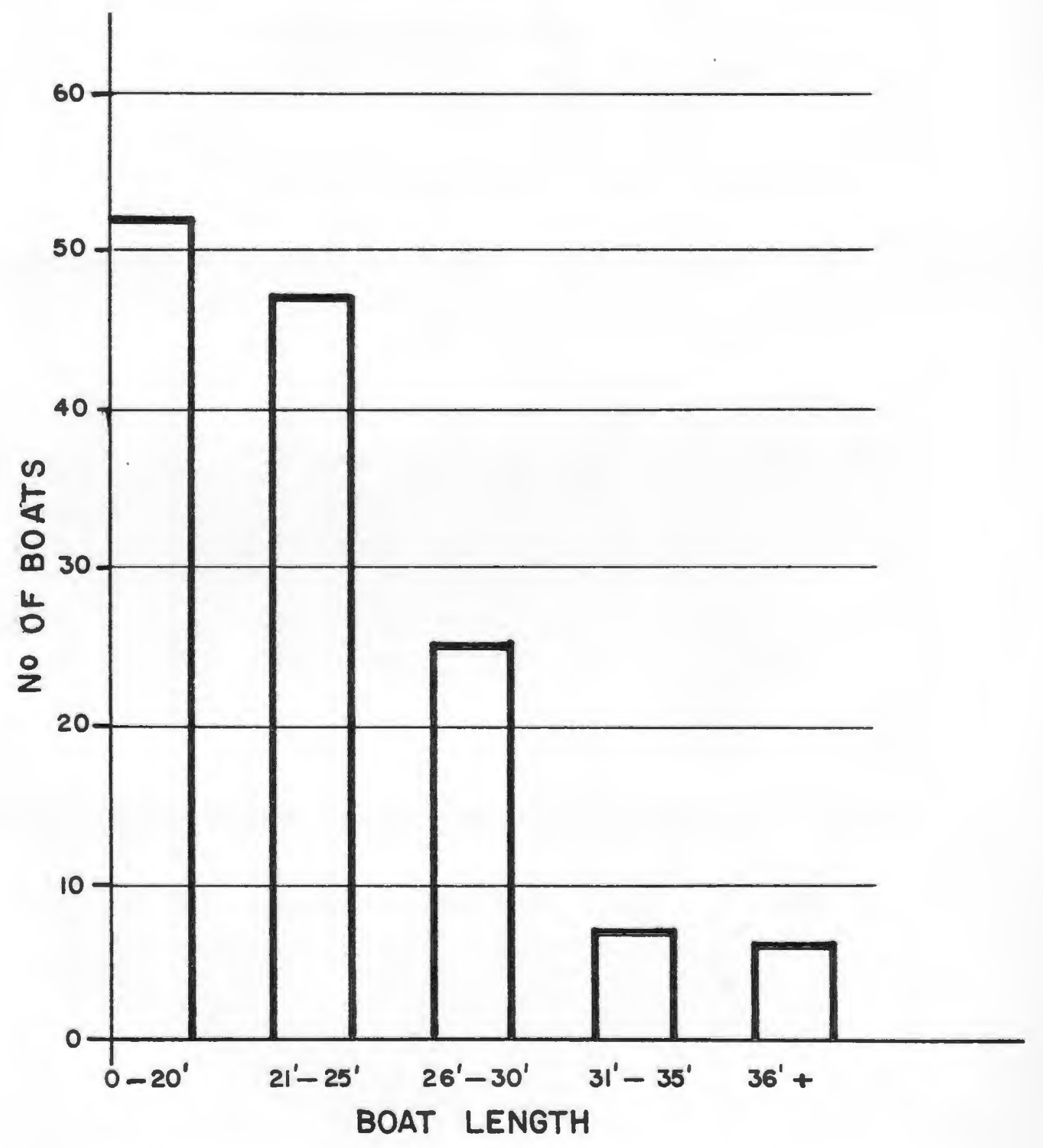


Figure P10A

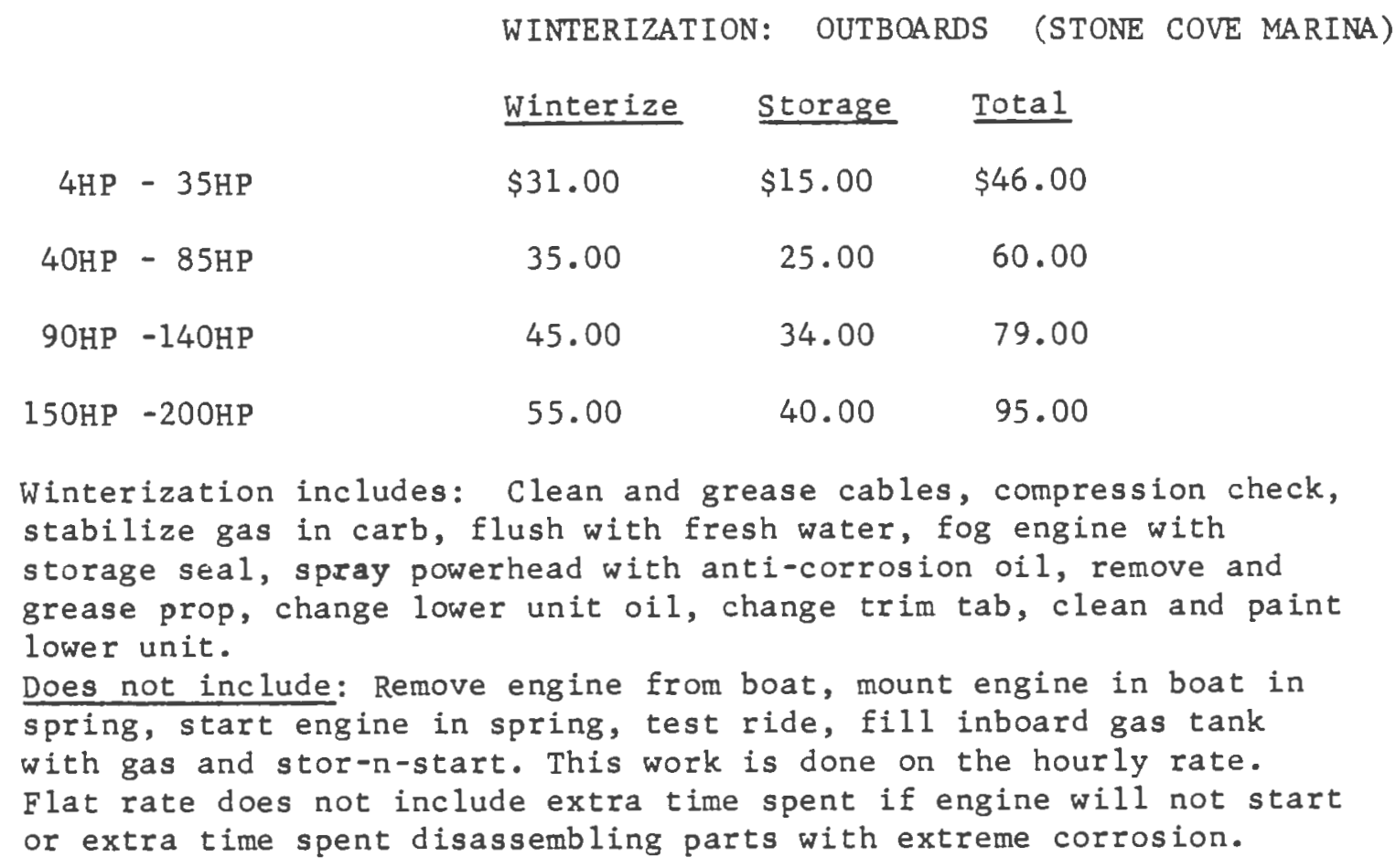

WINTERIZATION OF INBOARDS AND I/O ENGINES (STONE COVE MARINA)

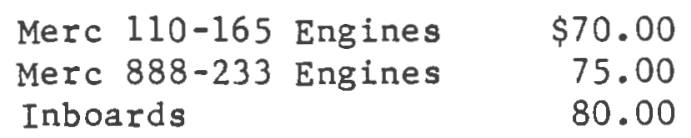

Winterization includes: $0 i 1$ and oil filter change, loosen fan belts, lubricate steering, fuel filter change, flush engine with frest water, fog engine with oil, spray engine with anti-corrosion oil, inspect engine. Gasoline and Stor-n-start billed according to amount used, labor included in winterization. Flat rate does not include extra time spent if engine will not start, or extra time spent disassembling parts with extreme corrosion. Flat rate does not include starting engine in spring. 


\section{Figure P10B}

\section{STORAGE CHARGES AND OTHER FEES (STONE COVE MARINA)}

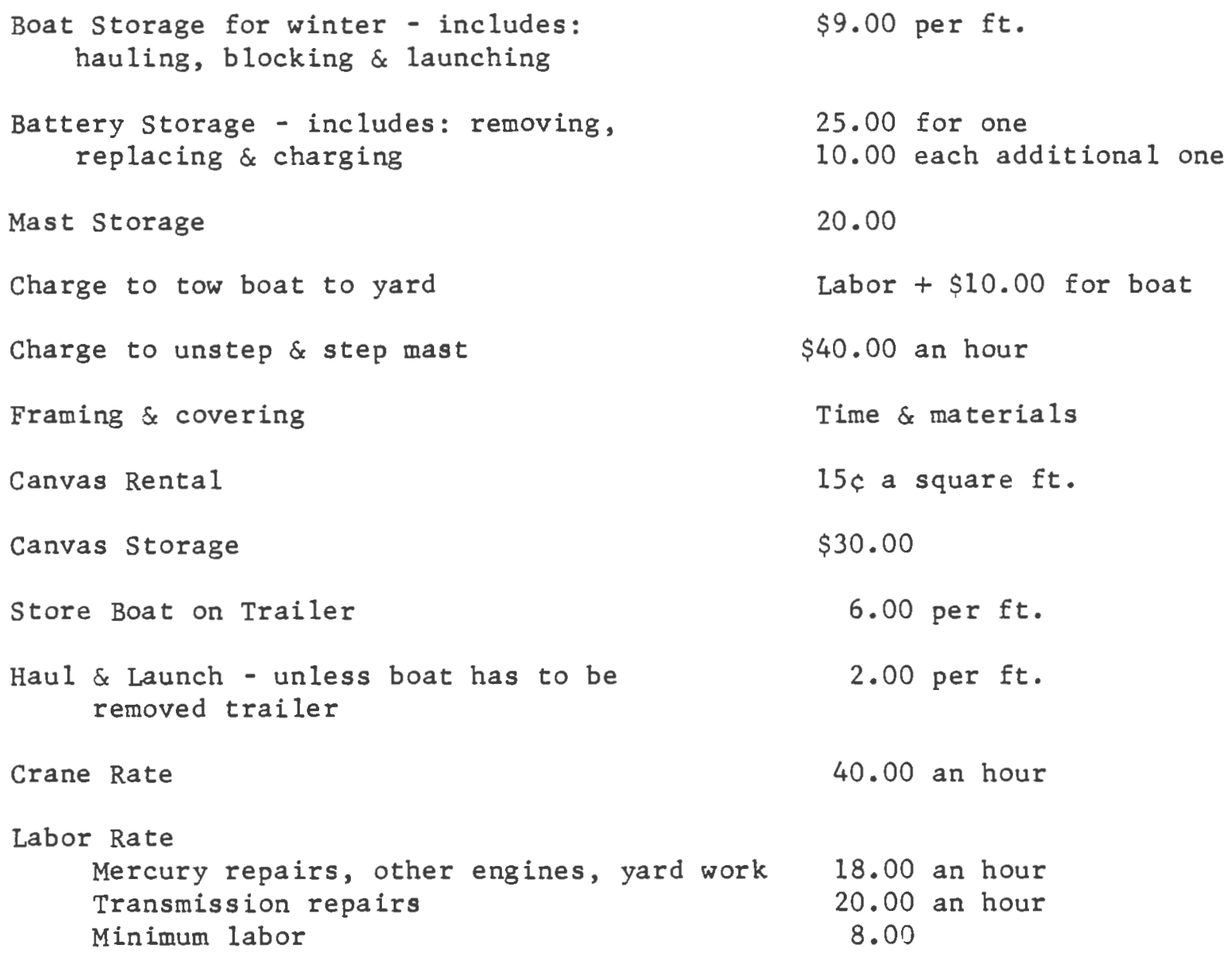

OUTDRIVES - WINTERIZATION AND STORAGE

Winterize Outdrives - $\$ 73.00$ - Storage $\$ 15.00$ - Total $\$ 88.00$

Includes: Remove from boat, grease all fittings, change lower unit oil, replace trim tab and annodes, clean outdrive, paint with antifouling paint, install with new gaskets. Pull prop and grease. Flat rate does not include extra time spent disassembling parts with extreme corrosion. 


\section{Cataumet Marina - Kingman Marine}

Cataumet Marina and Kingman Marine are names for two different divisions of the same organization. The marina organization rents the slips and moorings and Kingman Marine provides service to boats. For purposes of this paper a reference to either generally refers to this second case study marina as a wole.

Catamet Marina is locatod in the town of Bourne, Massachusetts, between the Pocasset and Cataumet neighhorhoods of the town. See Figure plat the beginning of the profile section for th location of the marina in the Ne England area. The neighborhoods are residential in character, with the marina and the Red Brook Harbor Boatyard immediately to its south constituting the only comercial operations in the local area. The layout of this area is shown in Pigure P11. Red Brook Harbor is a well protected natural harbor on the east shore of Buzzard's Bay. The harbor is protected from the north and northwest by wings Neck, and is protected on the south and southwest by Scraggy Neck. The open area between these necks is closed off to waves and swe 11 by Bassetts Island, making the harbor well protected from waves and swell from all directions. Mean range of tide is u.n feet. Cataumet Marina is at the extreme eastern end of Red Brook Harbor, about 1,500 vards (0.85 miles) from Bassetts Island. This is sufficient fetch to allow buildup of chop to the exposod portion of the marina 
docks, but only in severe storm conditions from the west or southwest is swell a problem in the harbor.

The marina is about three miles from abiels Ledge, which marks the entrance to the Hog Island Channel and the cape cod Canal. Dredged channels to both the north and south of Bassetts Island have a depth of 8 feet at mean low water, allowing easy access to the marina for all but the largest pleasure craft. The marina is thus in a convenient location for the large numbers of transient boats using the Cape cod canal. On the east side of Buzzard's Bay between the Canal and Hoods Hole there are 7 marinas with a total of 320 slips and 164 moorings. Cataumet Marina is the only large marina in this area, with 175 slips and 55 moorings. There is one yacht club in this area, the sandwich Yacht club, which has a small building wich it rents from the cataumet Marina. There is also one town owned pablic launching ramp in the area, and this abuts the catumet Marina property to the south. Purther, the Red Brook Harbor Boat Yard has 10 slips and 75 moorings. Thus it is apparent that Red Brook Harbor is the major center for boating activity on the east shore of Buzzard's Bay, accounting for 185 of 320 slips (about $58 \%$ ) and 130 of 164 moorings (about $79 \%$ ). Cataumet Marina alone accounts for approximately 55\% of the slips and $34 \%$ of the moorings in the area.

There is a significant concentration of marinas on the south shore of cape cod from Hoods Hole to Hyannis. Tom Kingman, owner of Cataumet Marina and Kingman Marine, considers those marinas (especially those in falmouth) to be his main competitors, but the authors feel that these marinas are in a 
different physical activity zone. The waters of vineyard sound are effectively separated from Ruzzard's Bay for many boaters by the passage through the hoods Hole channel. Tidal currents run at up to 8 knots through this channel, with large swirls and edies intimidating to those in small boats. sailing vessels often must wait for a fair tide to make the passage. Piqure P12 shows Buzzard's Bay, Vineyard sound, and illnstrates the importance of the Hoods Hole channel. Passage out and around cuttyhunk Island is time consuming and can be hazardous as well, due to strong tidal currents in the area. This is not to maximize the danger: there is generally no problem for competent boaters. But there is a definite element of inconvenience for the weekend boater or others with limited time and ambition. Also, there is a large traffic in cruising vessels between the Long Island sound area and cruising grounds Down Fast in Maine. Cataumet Marina is in the traffic flow of these boats, and the vineyard sound area is not.

The marina is also near the mainstream of traffic flow on 1and. The one remaining railroad line on the cape abuts the marina to the east. The line is in usable condition, and experimental trains were $r$ un on it during the summer of 1979. By car, access is as easy as any place on cape cod, being about 12 to 15 minutes from the Bourne Bridge, and about 20 minutes from the Sagamore Bridge. However, these two bridges provide access to all traffic to the entire cape, crossing over the canal. on holiday weekends, the bridges and their access roads are notorious for hours-long traffic jams (authors can testify). A typical Cataumet Marina customer, from the Boston 
area, can find that it takes as long to get through the town of Bourne as it did to get to Bourne from Boston.

ONNERSHP and EMPLOYMENT - TOM Kingman, and members of his immediate family, own both the marina business and the land it is situated on. The marina business was started as a boatyard in the 1930's by Mr. Kingman's father. Of the land now owned, about one-third was from the original boatyard, another third was acquired in 1944, and the final one-third was acquired in 1969. The present day layout of the marina is shown in figure P13. The inner yacht basin was dredqed out of an existing salt marsh, and the front area (where the Travelift is) was filled and altered considerably during a major expansion program in the early 1970's. This effectively changed the boatyard into the modern marina facility that it is today. Figure $p 14$ show zoning of land in the immediate area. There is no figure P15. Note that Mr. Kingman owns the commercial parcel between the marina and the town lauching ramp. This parcel is to be utilized in future development. Eventually, Mr. Kingman would like to acquire the Red Brook Harbor Boat Yard as vell, and have one large, intearated facility on the harbor.

The area containing the marinas is zoned $\mathrm{B}-2$, a business zone designed "To accomodate general business development in areas sarviced by major traffic arteries, and where conflict with residential development will not be substantial" (Bourne Zoning Bylaws: $p .7)$. The area to the north and east is zoned R-20, residential with 20,000 square foot minimum 1 ots. The area to the south is zoned $\mathrm{R}-40$, residential with 40,000 square 
foot minimum lot size. Historically, the boatyards we re in operation and the surrounding residential area was sparsely developed with large estate properties, from the end of World War II until the late $1960^{\prime} \mathrm{s}$. At that point, subdivision began and now the area is more densely developed. It is far from the typical subdivision, though, and most of the homes could be described as luxurious. There is at present some tension between this we11-moneyed reighborhood and its commercial neighbor, the marina. Mr. Kingman understandably regards these neighbors as latecomers who, now that they have achieved their material success, want no further change. The neighbors, equally understandably, are concerned about preserving the character of the area and the cleanliness of the beaches they have worked so hard to obtain. overall, the development process appears to be well regulated by the Bourne town administrative mechanism. The town selectmen have a shore and Harbor committee, and there is a conservation commission as we11 as the usual Planning Board active in the town.

Employment - The organization of the Kingman businesses is shown in Fiaure p16. The biqgest employer is the Chart Room Restaurant, with over 50 employees. Direct enployees of Mr. Kingman number 31, with 8 in the store, 2 in the parts department, and 21 employess directly concerned with the care and servicing of boats. The marina has recently undergone a change in Kingman Marine, the service organization, to provide for better comprehensive service to customers and better stability for year-round employment to help keep competent staff. The system has better fiscal accourtability and should 
lead to increased profitability.

FACILITIES - Cataumet Marina occupies approximately 7.2 acres of land. The inner yacht basin takes up 4.2 acres of water, and the undeveloped parcel owned by the marina for expansion is 3.5 acres. There are 9 major buildings on the site. Kingman Marine service facilities occupy 4 of these. with space for mechanics shops and indoor storage. The store. gift shop, parts department, and administrative offices occupy another large building. The restaurant and grocery share a building, the sandwich Yacht club has a club house building. and there are two separate facilities with heads and showers, one of which houses a laundromat. Two of the large boat storage buildings and the store/office building are relatively new, of the quickly erected "Mi+chell" or "Butler" metal type. The head and shower facility at the upper end of the yacht basin was completed during tho 1979 sumer season. The remaining buildings have been well maintained and all appear to be in good condition. There is no town sewer hookup, but there are several leach fields which have been recently upgraded and which are carefully monitored.

special attention has been given to landscaping and aesthetics at the marina. The Chart Room restaurant is very busy during the season, and the entire area of the marina near the restaurant has been planted with lawns, shrubs and flowers. Carefully placed nautical objects such as a flagpole, cannon, and anchor enhance the park-like atmosphere. The business end of the yard, near the Travelift, has not been landscaped but 
has carefully been kept clear of the usual piles of rusting odd bits and pieces. Mr. Kingman views his facility as a place of "public access", and maintains that the benefits outweiah the costs of keeping the marina neat and attractive. The customer parking area for the restaurant and store nas been newly paved. The parking for boat owners is surfaced $v i+h$ crushed rock, and the working surface of the yard is gravel. $\$ 11$ shore edges in the marina are faced with rip-rap to prevent erosion.

In the water, there are two distinct areas of slips. The inner yacht basin, as previously mentioned, was dredged from a salt marsh, and is completely protected, yith 8 feet of water at low tide. The largest yachts are kept along the entrance channel to the basin, and for several years were protected by a floating tire breakwater, ar experiment deemed successful. (In the spring of 1979 the binding materials failed and the tires were removed, but replacement on a larger scale is being considered.) More exposed to the harbor chop are the outer docks, with the fuel dock at their tip. In contrast to the rest of the marina's facilities, these docks are not in good condition, and replacement altornatives are being evaluated. These outer docks are used largely for transient docking. Access to the moorings offshore is from these outer docks, with dinghies lined up along the edge of the "O" dock. There is sufficient fetch to the west toward Bassetts Island for a chop to develop, which is a problem at the outer docks. In severe local storms, swell from Buzzard's Bay refracts successfully into the harbor, which also creates a problem at these docks. Aditionally, there is a possibility of surge, the area being 
classified in Flood zone A-8. The probability is for a 13 foot flood level on a 100 year basis (HIID - FTA, 1976). In the 1954 hurricane there were 6.5 feet of water in the kingman Marine service building. There are no routine tide current problems, but the upper end of the yacht basin flushes slowly.

All docks have fresh water, and there is 30 and 50-amp electrical service with heavy duty hookups. Each electric hookup unit has a shielded footlight on top, and the docks are well lit by these at night. The overall distribution of slips is shown in Pigure P17. Of the 177 slips, 139 are in the inner yacht basin ard 38 are on the outer docks. The slips 1isted as "available to transients" are the number not rented to seasonal customers out of those available. In addition to slips, Cataumet has 46 moorings, 6 of which are reserved for transients. The docks are in good condition in the yacht basin, and in fair condition in the outer area, as noter previously. The inner basin is kept open during the winter with bubblers, and some boats are wet stored there. The outer docks are removed for the winter season.

Boats are bauled and launched using a 35-ton Travelift and a 15 ton mobile crane. There is both indoor and outdoor storage on land as well as wet storage. Standard blocks and jacks are usen to support the boats, complete service facilities for boats and mechanical components are available. Although new boats are dot sold, there is a yacht broker at the marina. Ancillary services at cataumet Marina are very complete, including the restaurant, grocery, gift shop, and a large ship's store. See figure p18 for a comparative checklist 
of services offered by the two case study marinas.

security is taken care of during the sumer season by a hired security service. Year round, Mr. Kingman lives on the premises, his presence providing security in the off season. There are 4 fire hydrants on the marina grounds, with numerous fire extinguishers in the buildings. There is a large fire extinguisher available on the qas dock. The marina is a dealer for Mobil oil. Figure p19 shows sales of qasoline and diesel fuel during the 1978 and 1979 seasons. Gasoline sales were almost at the 1978 level during the 1979 season, at a total volume of just three percent less. Diesel sales were down by 17\% however, a major drop. The marina did not run out during the season, but had more difficulty obtaining fuel than in past yคars.

CUSTOMERS and THEIR BOATS - Pigure P20 shous the physical distriution of Cataumet Marina customers in the New England area. The marina is represented hy a trianqular symbol, and the dots are distributed using the same method as was used in Pigure P5 for stone Cove Marina. Cataumet's customers are fairly evenly distributed +hroughout southeastern Massachusetts and in the Boston suburbs. The percent breakdown of customers by radius, in fiqure P21, shows a 50-50 split at the 50 mile distance. According to the travel times shown in Pigure p8, this means that more than $50 \%$ of the marina's customers live over an hour avay. The summer traffic jams can add considerably to this travel time. $48 \%$ of the customers live between the 50 mile and 75 mile radii, indicating that this is 
the maximum range of the practical access area for the marina, i.e. very few customers, only about 8 , are willing to come from further away. Towns with more than one customer are shown in Figure P22.

The boats at cataumet are used primarily on weekends: customers spend the weekend eitber cruising or in the marina. The size distribution of the boats shows this. Figure P23 shows the size distribution of boats, with the 26 to 30 foot class being largest, and a clear majority of boats being over 26 feet in 1 ength. The marina has seen a trend towards sail in recent years, and now about $41 \%$ of all seasoral customers own sailboats. The majority of these have overnight accomadations. A further breakdown of boat size, including the number of pover and sail boats, is shovn in Pigure P24.

RATES - Basic rates for the 1980 summer season are $\$ 30$ per foot for all size boats, outside winter storage is $\$ 12$ per foot. All other services, and their rates, are shown in Pigures P25a and P25b. 
Figure P11

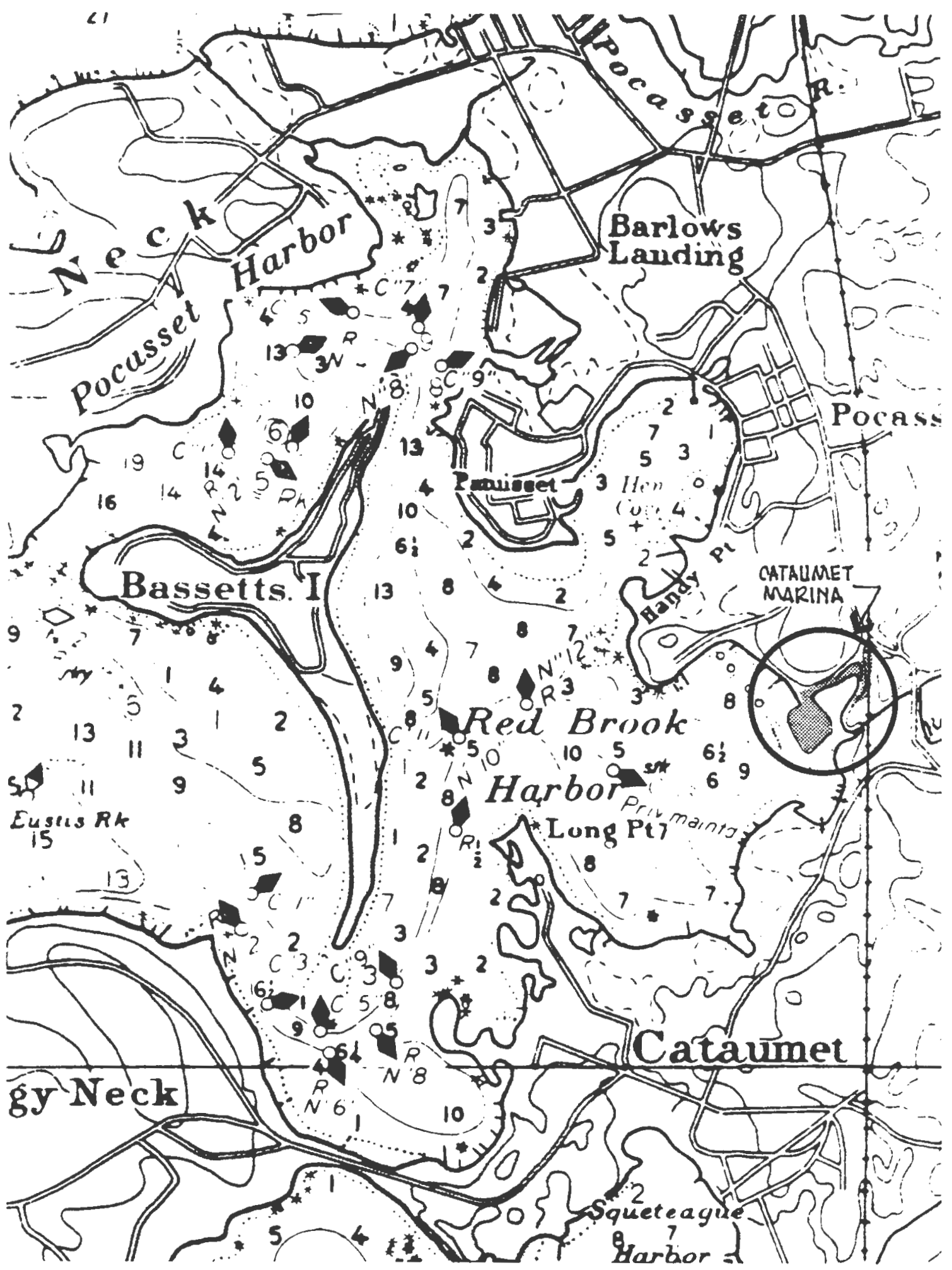




\section{Figure P12}

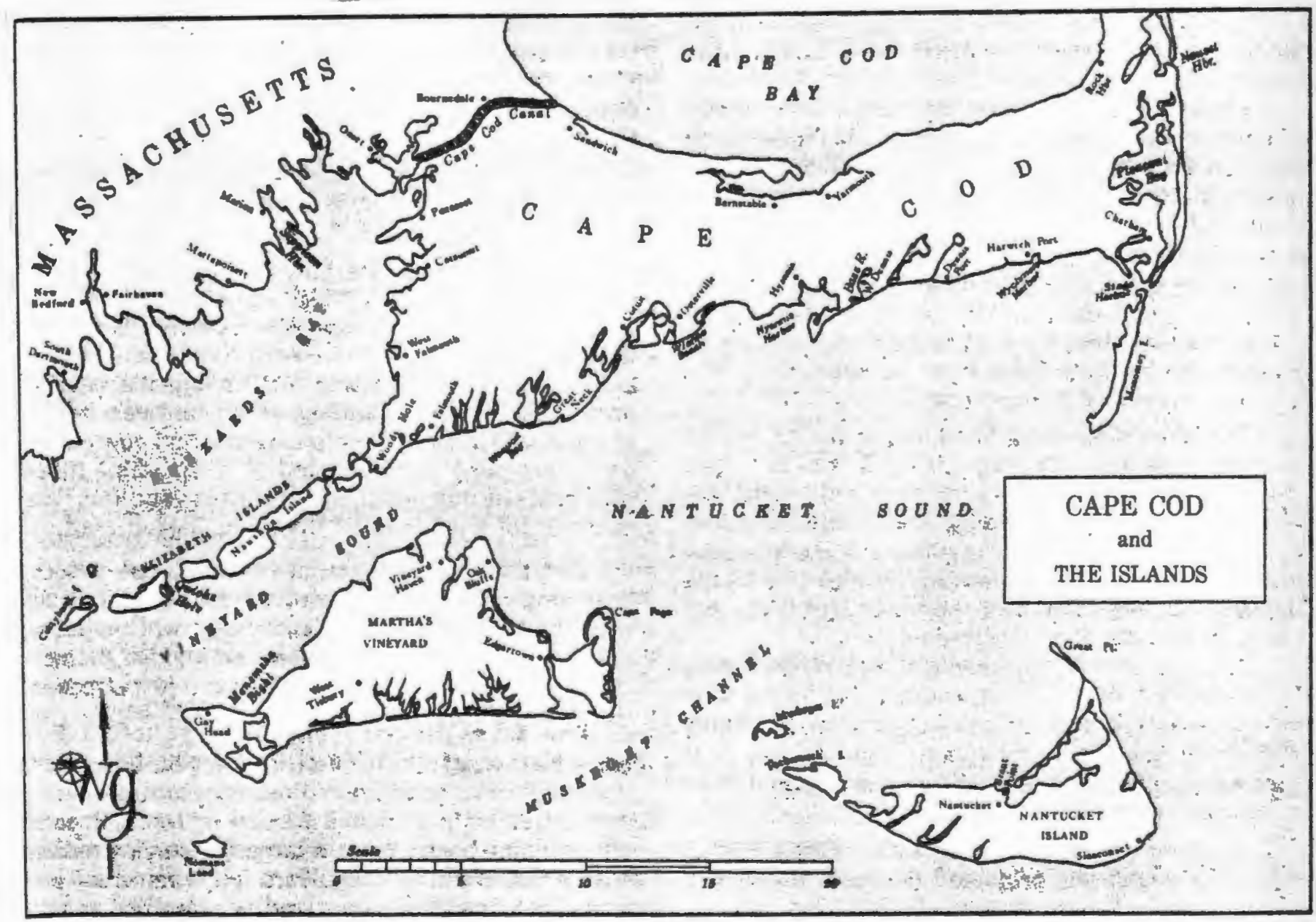


1. Slipg area: IA - inner yacht basin

2. Fuel dock

IB - outer floats

3. Lift wel1

4. Yard working area/ winter storage

5. Sales, administration

6. Service, indoor storage

7. Restrooms, showers

8. Outdoor equipment storage

9. Public launching ramp

10. Marina owned property for expangion

11. Public parking

12. Merina parking

13. Restaurant

14. Yacht Club, storage shed

15. Dockmaster's shed

$\begin{array}{lc} & \text { Total } \\ \text { Moorings } & 55 \\ \text { Slips } & 180 \\ \text { Parking spaces } & 220\end{array}$
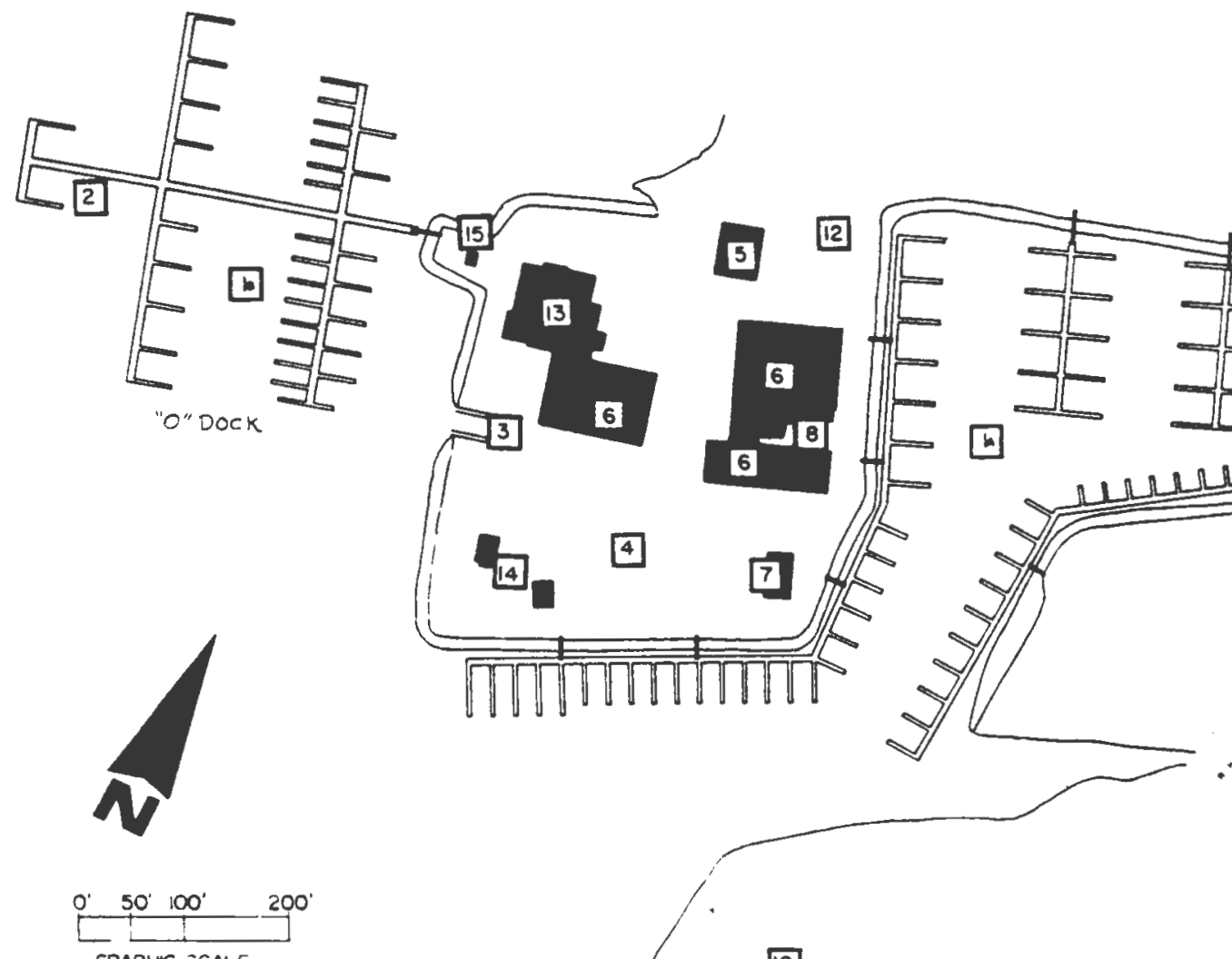

GRAPHC JCALE

10

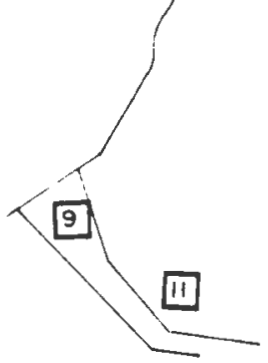




\section{figure P15}

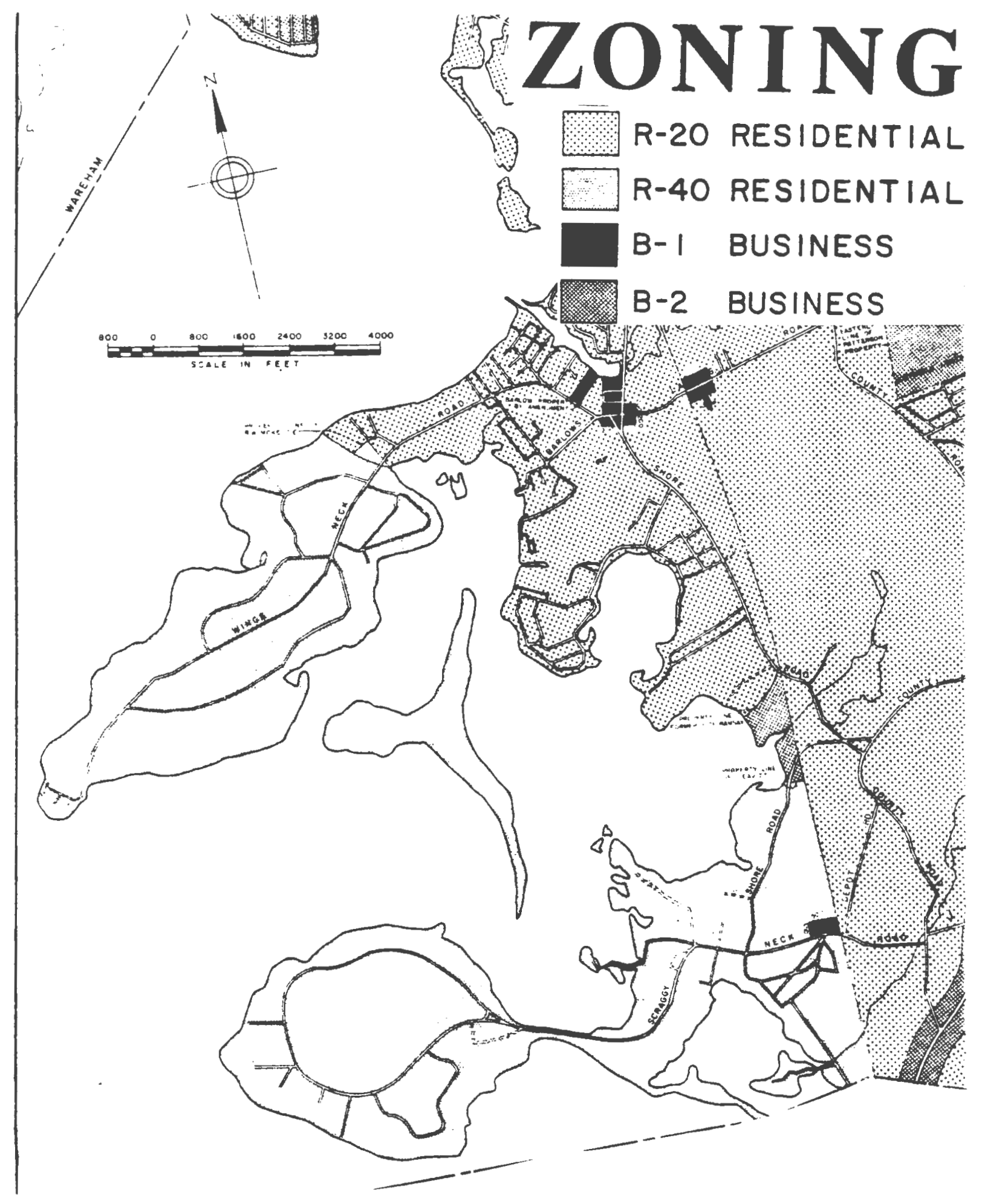


Cataumet Organizational chart

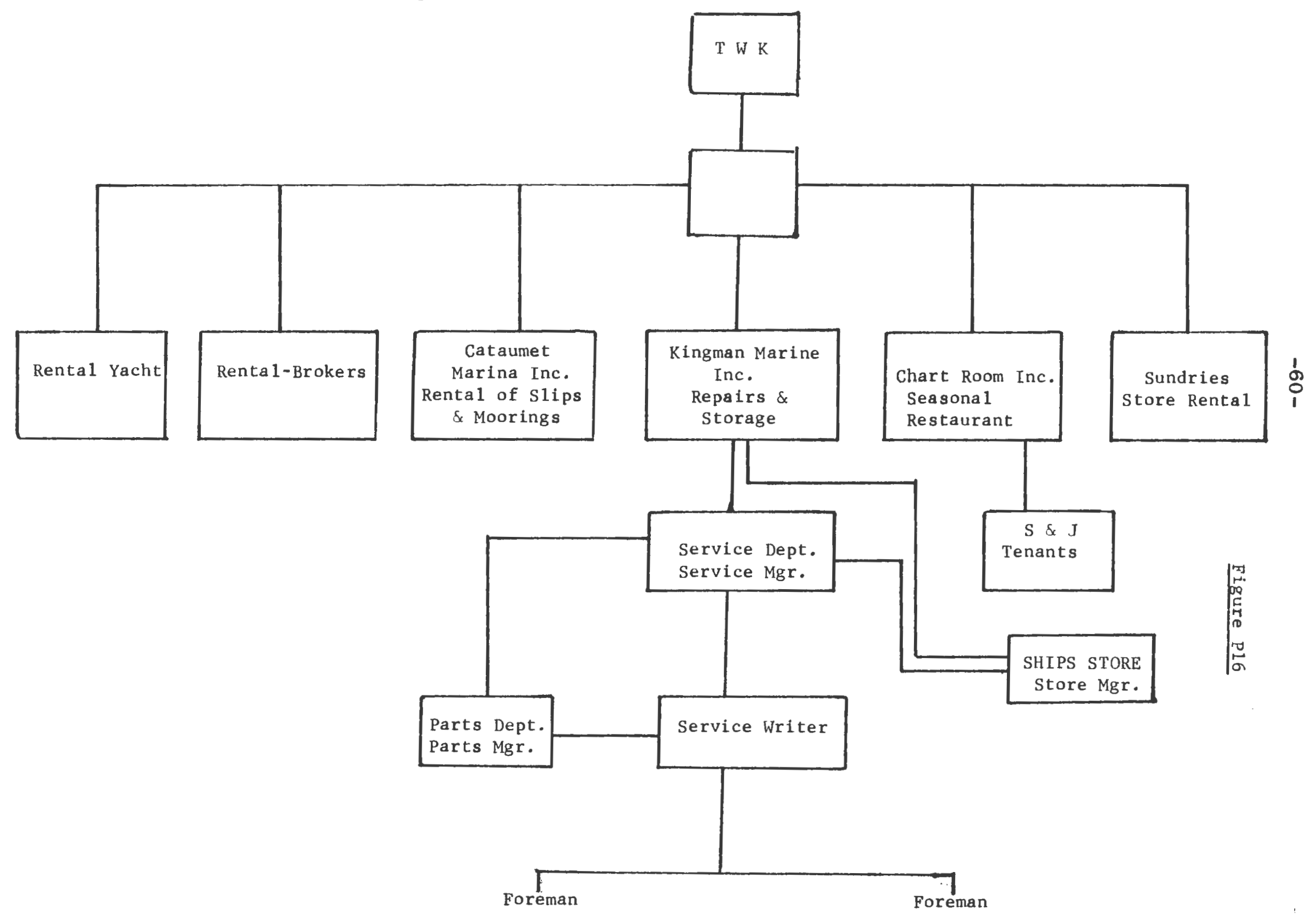


Figure P17

DISTRIBUTION OF SLIPS - CATAUMET MARINA

\begin{tabular}{rrr} 
\# of slips & length & \# available for transients \\
\hline 6 & $50^{\prime}$ & 1 \\
43 & $40^{\prime}$ & 7 \\
73 & $30^{\prime}$ & 10 \\
6 & $25^{\prime}$ & 0 \\
49 & $20^{\prime}$ & 2
\end{tabular}

Figure P19*

FUEL SALES - CATAUMET MARINA - in gallons

\begin{tabular}{llll} 
& 1978 & 1979 & $\%$ change \\
\hline Gasoline & 83,504 & 80,736 & $-3 \%$ \\
Diesel & 24,404 & 20,207 & $-17 \%$
\end{tabular}

* Figure P18 is on the next page 
Figure P 18

MARINA FACILITIES CHECKLIST

Wave Protection

Slips

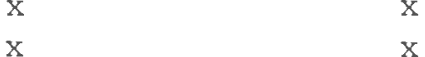

Moorings

Fue 1 Dock

Electricity

Fresh Water

Telephone

Rest Rooms

Showers

Trash Disposa 1

Ice/Beverage Machines

$x$

Auto Parking

Fire Extinguishers

$\mathrm{x}$

$\mathrm{x} x$

$\mathrm{x} x$

$x-x$

$\mathrm{x} x$

$\mathrm{x} x$

$\mathrm{x} x$

$\mathrm{x} x$

First Aid Kit

Area Lighting

Security

Boat Hauling/Launching

Boat, Engine Repair

Boat Parts

Indoor Storage

Outdoor storage

$\mathrm{x}$

$\mathrm{x}$

$\mathrm{x}$

$\mathrm{p}$

$\mathrm{x}$

$\mathrm{x}$

$\mathrm{x}$

$\mathrm{x}$

Wet storage

New Boat Sales

Brokerage

Boating Accessories

Lures and Tackle

Owner-repair Area

Laundromat

Grocery/sundry

Restaurant

Gift Shop

Landscaping

$\mathrm{x}$

$x$

$\mathrm{P} \quad \mathrm{x}$

$\mathrm{x} x$

$\mathrm{x}-\mathrm{x}$ 


\section{figure P20}

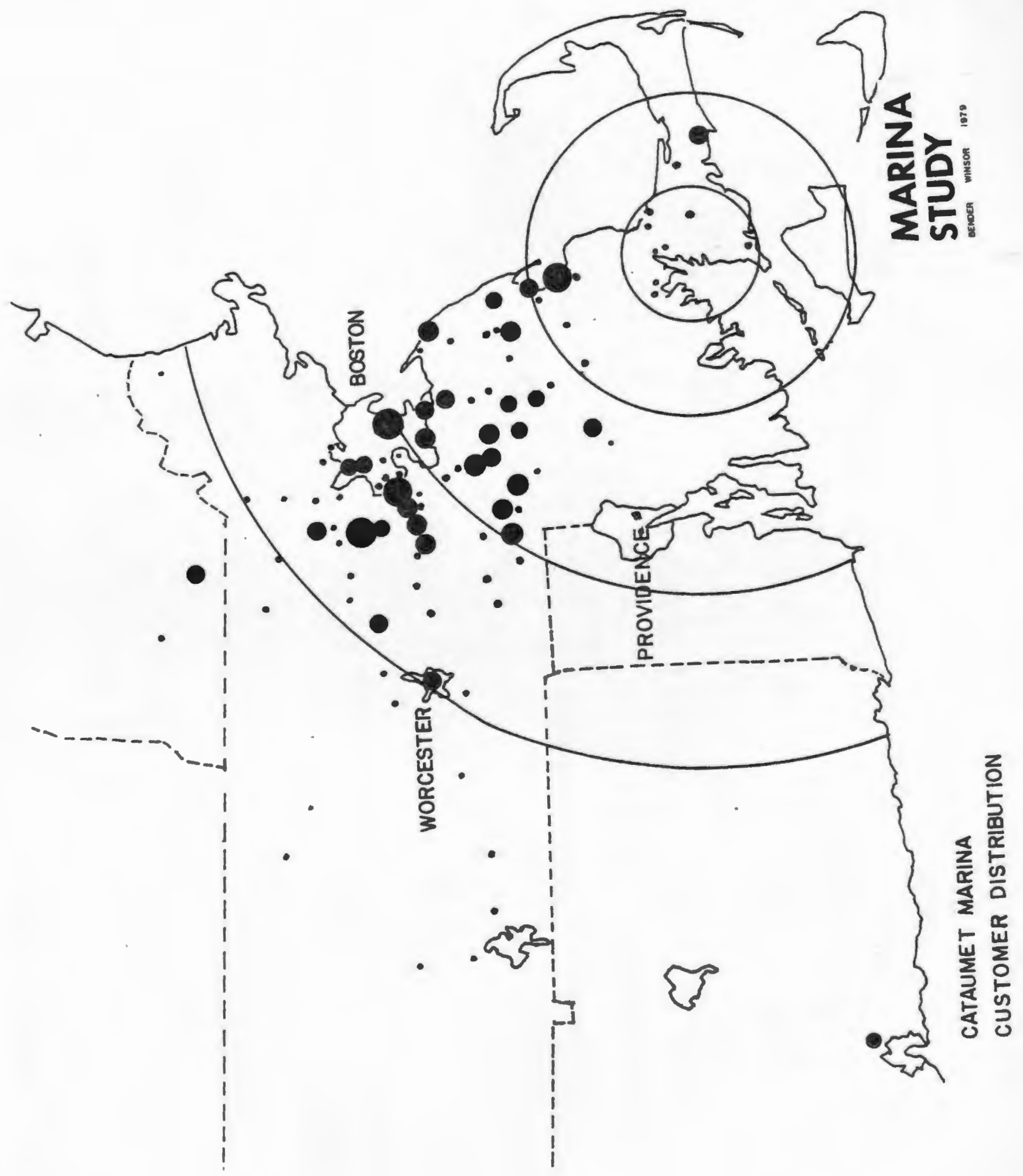


Figure P21

Distance of Seasonal Boat Owners from Cataumet Marina

Radius

$\%$ of owners living within Radius

10 miles $12 \%$

25 miles $20 \%$

50 miles $50 \%$

75 miles $92 \%$

Figure P22

Towns with more than one customer - Cataumet Marina

Category

Town or City

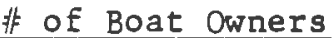

Within 10 mile radius

Pocasset

Sandwich

Falmouth

5

Bourne

Monument Beach

Wareham

(a1so:) (Forestdale

(East Wareham

1)

1)

Within Massachusetts:

Newton

Plymouth

Boston

Sudbury

Canton

Framingham

Cohasset

Frank1in

Foxboro

Braintree

Bridgewater

Norfolk

Pembroke

Stoughton

Wayland

Wellesley

Worcester

Acton Arlington

Brockton Duxbury

Bolton

Hyannis

Natick

Sharon

Marshfield Milton

N. Easton Quincy

Taunton Woburn

Welling ford, CT

Outside Massachusetts:

Nashua, NH

Other: (off map)

Morrisville, VT

Philadelphia, PA

Rockville, MD

1

1 
$-65-$

DISTRIBUTION

OF BOATS

BY LENGTH

CATA UMET MARINA

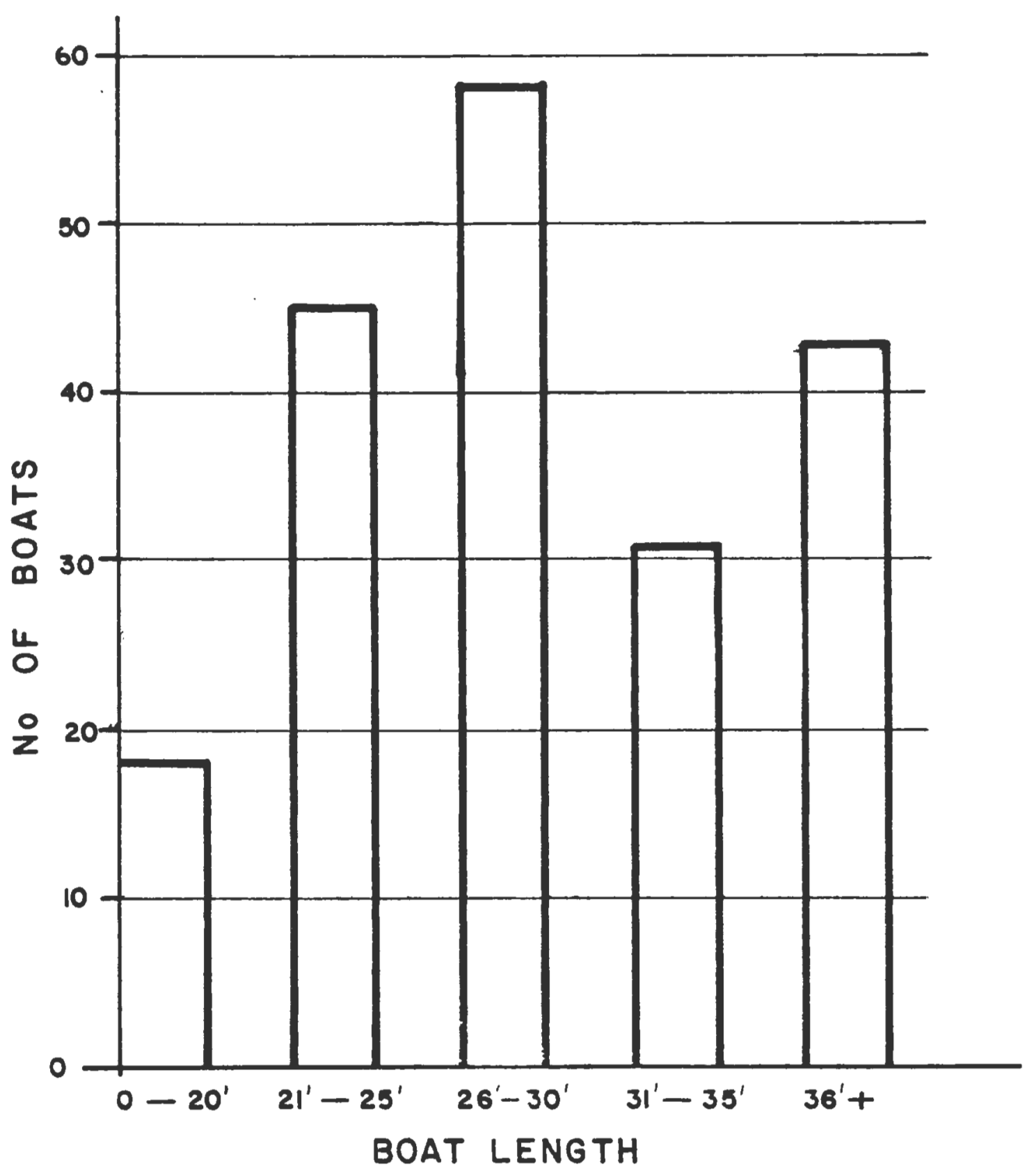


$-66-$

Figure P24

CATAUMET MARINA

SEASONAL BOATS BY LENGTH

AND TYPE

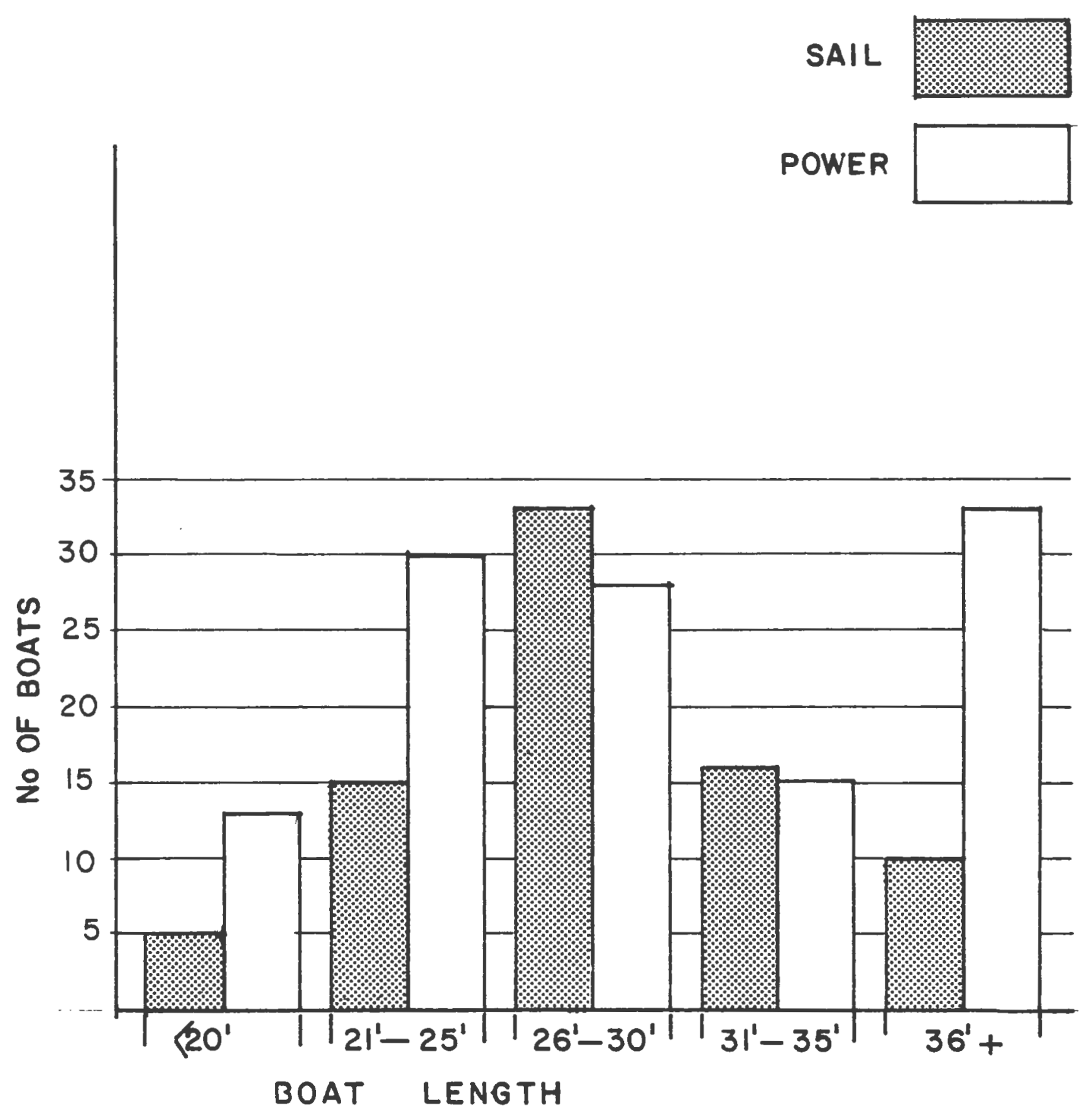


ALL rates determined by extreme length including all appurtenances attached thereto, 1.e., pulpits, bowsprits, dinghys, davits, swim platforms, etc. Fractional footages figured to the next whole foot.

\begin{tabular}{lrl}
\multicolumn{2}{l}{ Outboard } & Slips \\
25 & Foot & Slips \\
30 & Foot & Slips \\
40 & Foot & Slips \\
50 & Foot & Slips
\end{tabular}

$$
\begin{aligned}
& \$ 560 \text { plus } \$ 30 / \text { foot over } 20 \text { feet } \\
& \$ 750 \text { plus } \$ 30 / \text { foot over } 25 \text { feet } \\
& \$ 900 \text { plus } \$ 30 / \text { foot over } 30 \text { feet } \\
& \$ 1200 \text { plus } \$ 30 / \text { foot over } 40 \text { feet } \\
& \$ 1500 \text { plus } \$ 30 / \text { foot over } 50 \text { feet }
\end{aligned}
$$

All slips have one 30 or one 50 ampere individual circuit breaker electrical outlet per vessel, 125 volts, and fresh water outlet. Telephone connection available on new yacht basin docks and arranged through New England Telephone - Falmouth office.

Vessels in larger slips are required to use 50 AMP outlets and vessels in smaller slips are to use 30 AMP outlets $1 f$ there is a lack of outlets of smaller capacity.

A second power cord, use of 2 outlets, use of $Y$ adapter with 2 cords, or use of 220 volt outlet is an additional charge of $\$ 125.00$ per season.

If no large dock is available, and smaller dock is assigned to accomodate larger boat, customer will pay rate of larger dock.

MOORINGS \$375 minimum

$$
\begin{aligned}
& \$ 400-40 \text { foot and over } \\
& \text { Daily }-\$ 5.50
\end{aligned}
$$

All diaghys shall be kept upside down on outer (O) dock.

DAILY DOCKAGE

$$
\$ .60 \text { per foot per day }
$$

At the termination of a seasonal or period rental, charges will be figured at a daily rate. Anyone using a slip or mooring before or beyond the contract period will pay the daily transient rate. There are no refunds on deposits or payments.

\section{STORAGE /PARKING SPACE FOR TRAILERS}

$$
\begin{aligned}
& \$ 2.00 \text { per day } \\
& \$ 10.00 \text { per week }
\end{aligned}
$$

Prices subject to change without notice.

Complete rules, regulations, terms and conditions, charges and rates are posted in the Dockmaster's and main office.

SPECIAL RATES/SPACES FOR SKIFFS/WHALERS UNDER 13 feet. 


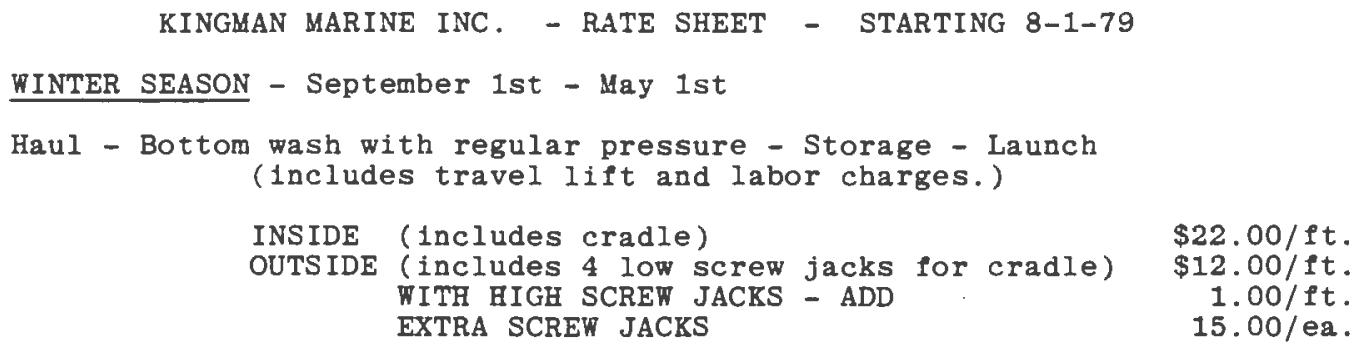

$\$ 20.00 /$ ea. $35.00 /$ ea. $45.00 / e a$.

PER MAST

DUST COVERS FOR INSIDE STORAGE

Labor and materials

STORAGE ONLY - MISCELLANEOUS

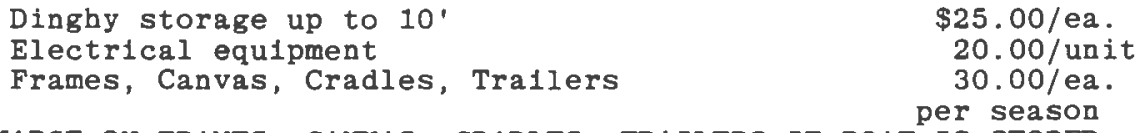

25.00

35.00

45.00

Up to 200 horsepower

Winterize of above includes flush, rinse, fog, grease, and

oil lower unit. Removal and reinstallation of unit

will be done at an hourly labor rate.

INBOARD/OUTBOARD - LOWER UNIT ONLY

Remove - store - change oil - reinstall.

Includes all labor. Materials extra.

$\$ 75.00 /$ ea.

MAINTAIN BATTERIES - SmaII

$\$ 15.00 /$ ea.

- Large

$25.00 / \mathrm{ea}$

Removal and reinstallation will be done at an hourly labor

rate. 
ENGINE AND FRESH WATER SYSTEMS

AS NO TWO BOATS ARE THE SAME AS TO ENGINE AND FRESH WATER SYSTEMS LOCATION AND ACCESSIBILITY - all winterizing and sumerizing of

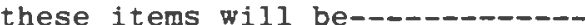

LABOR \& MATERIALS

OTHER REPAIRS AND MAINTENANCE

LABOR \& MATERIALS

ALL RATES BELOW ARE PLUS LABOR AND MATERIALS AS REQUIRED

\begin{tabular}{|c|c|c|}
\hline $\begin{array}{l}\text { CRANE } \\
\text { TUG - Ghost Rider } \\
\text { TRUCK } \\
\text { HAUL \& LAUNCH (not removed from slings) } \\
\text { HAUL OR LAUNCH } \\
\text { JaCk stands or blocking when used on hau] }\end{array}$ & $\begin{array}{l}(\$ 17.50 \text { minimum) } \\
(20.00 \text { minimum) } \\
(15.00 \text { minimum) } \\
\text { (plus labor) } \\
\text { (plus labor) } \\
\text { outs }\end{array}$ & $\begin{array}{l}\$ 35.00 / \mathrm{hr} \text {. } \\
40.00 / \mathrm{hr} \text {. } \\
.20 / \mathrm{mi} \text {. } \\
3.00 / \mathrm{ft} \text {. } \\
2.00 / \mathrm{ft} . \\
1.00 / \mathrm{day}\end{array}$ \\
\hline DIVING & Minimum & $40.00 / \mathrm{hr}$. \\
\hline SUMMER STORAGE ON LAND & & $\begin{array}{l}\$ 6.00 / f t \\
\text { per mont }\end{array}$ \\
\hline IET STORAGE ( Cataumet Marina)-WINTER - & $/ 1$ through $5 / 1$ & $\begin{array}{l}\$ 5.50 / f 1 \\
\$ 22.00 / \mathrm{h}\end{array}$ \\
\hline
\end{tabular}

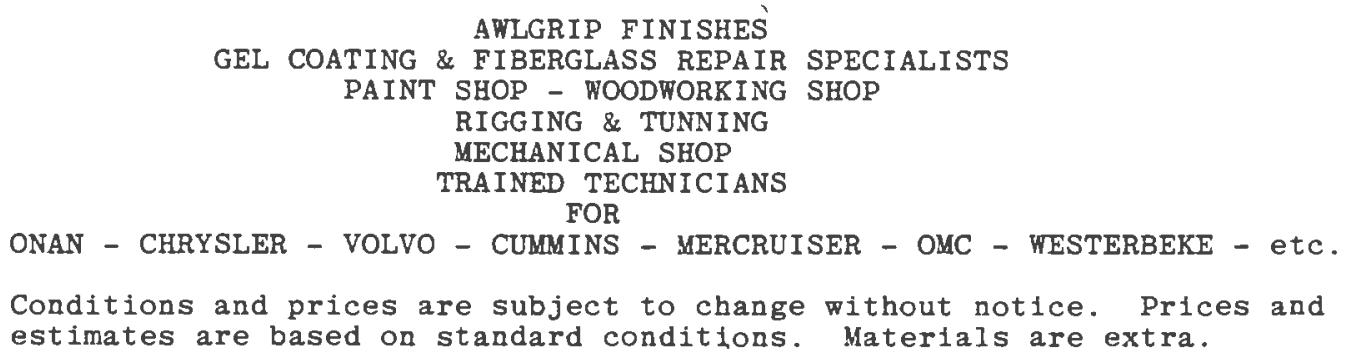




\section{CASE STUDY COMPARISONS}

There are several differences between the two case study marinas wich are of major importance. The first and most obvious is the overall size of each, stone cove, with 145 boats has apnroximately $62 \%$ the capacity of cataumet. There is also is a disparity in the land area taken up. Stone cove having 3.1 acres and Cataumet occupying 7.2 acres. The marinas facilities checklist (refer back to Pigure P18) shows that both marinas offer a fairly complete array of services. Cataumet has a laundry, gift shop, restaurant, grocery, and landscaping, none of which are to be found at stone cove. on the other hand, stone cove sells new boats and motors, while Cataunet Marina does not, In addition, Cataunet offers a yacht broker, and in the sumer season has a hired security service.

Both marinas are of larger than averagu size, as shown by Figure P26, which lists distribution of marina sizes for a variety of sources. This in turn allows both marinas to provide the relatively complete service base just discussed.

The otber major area of difference is in the makeup of the customer population, and the resulting contrast ir. market area. Figure P27 sumarizes the cumulative number of customers 1 iving within given radii of each marina. The stone cove customers live largely within Rhode Island, and over three-fourths are within an hour's drive, The market area is made up mostly of the local towns and the providence metropolitan area. Eataunet 
custoners live further away from the marina as a whole. Cver 40\% live more than 50 but less thal 75 miles from the marina, and 50\% live over an hour's dive away. The cataumet market area comprises southeastern Massachusetts and the Boston metropolitan area. Figures 95 and P20 in the profiles sections show the customer distribution for stone cove and cataumet Marina, Iespective $1 y$.

Paralleling the difference in market areas is a difference in the types of boats, and their use, found at each marina. Stone Cove has over $90 \%$ power boats, and the primary use is तay trips for fishing. The average boat size is under 25 feet. Cataumet Marina has $41 \%$ sailboats and $59 \%$ power boats, and the typical use is cruising or fishing, but with the difference that the niglt is generally spent aboard over a weekend. Figure $\mathrm{P} 28$ is a histogran which shows the number of boats in five different length classes found at each marina. A clear difference is shown in the under 20 foot class, which is the largest class for stone cove, and the smallest for cataumet. Cataumet has a large number of boats over 31 feet in length, and stone cove relatively fow. As percentages of the total fleet at each marina, 9\% of the boats are over 31 feet at stone Cove. while $38 \%$ of the hoats at cataumet are in this class. Figure P29 shows the distribution at both marinas as percentages, compared with data from a survey of Narragansett Bay done in 1972 (Kolluy and Rorholm, 1974). The longth categories have been changed from the previous fiqure to conform with Kelley and Rorholm's data. It shows that the distribution of boats at stone cove is generally in conformance 
with the distribution of boats by length in Narragansett Bay in 1972. The relatively high percentage of large boats at Cataumet Marina is further emphasized by this length distribution. Unfortunately a similar overall distribution for Buzzard's Bay is not available for comparison. It should be pointed out, however, that Cataumet Marina actively seeks out larger boats, as they feel that this is the most desirable customer class, stone cove, in contrast, prefers customers in the "around 25 foot" class, their experience having been different from Catauet's. Both marinas will be pressured in the future to cater to the ever increasing number of smaller boats, in the under 25 foot class. 
Figure P26

NUMBER OF MARINAS OF GIVEN SIZE FOR DIFFERENT SAMPLE AREAS

$\%$ OF MARINAS, BY SIZE

\begin{tabular}{llccc}
\hline $\begin{array}{l}\text { AREA, DATE } \\
\text { (SOURCE) }\end{array}$ & $\begin{array}{l}\text { NUMBER OF } \\
\text { UNDER }\end{array}$ & $\begin{array}{c}\text { BOATS : } \\
\text { UNO-99 }\end{array}$ & $100-199$ & $200+$ \\
\hline $\begin{array}{l}\text { USA, 1964 } \\
\text { (NAEBM) }\end{array}$ & $50 \%$ & $25 \%$ & $15 \%$ & $10 \%$ \\
$\begin{array}{l}\text { Rhode Is land, 1972 } \\
\text { (Ke1ley \& Rorholm) }\end{array}$ & $39 \%$ & $26 \%$ & $28 \%$ & $8 \%$ \\
$\begin{array}{l}\text { Narragansett Bay, 1977 } \\
\text { Narragansett Bay, 1979 }\end{array}$ & $33 \%$ & $24 \%$ & $25 \%$ & $17 \%$ \\
Buzzards Bay, 1977 & $39 \%$ & $25 \%$ & $25 \%$ & $17 \%$ \\
Buzzards Bay, 1979 & $41 \%$ & $33 \%$ & $9 \%$ & $18 \%$ \\
\hline
\end{tabular}

al1 figures rounded to nearest percent

\section{Figure P27}

DISTANCE OF BOAT OWNERS FROM MARINAS

\begin{tabular}{lcc} 
Radius & $\begin{array}{c}\text { Cumulative } \% \text { of owners living within Radius } \\
\text { Stone Cove }\end{array}$ & $\begin{array}{c}\text { Cataumet } \\
\text { 10 Miles }\end{array}$ \\
\hline 25 Miles & $27 \%$ & $12 \%$ \\
50 Miles & $51 \%$ & $20 \%$ \\
75 Miles & $78 \%$ & $50 \%$ \\
\hline
\end{tabular}


Figure P28

\section{DISTRIBUTION OF BOATS BY LENGTH}

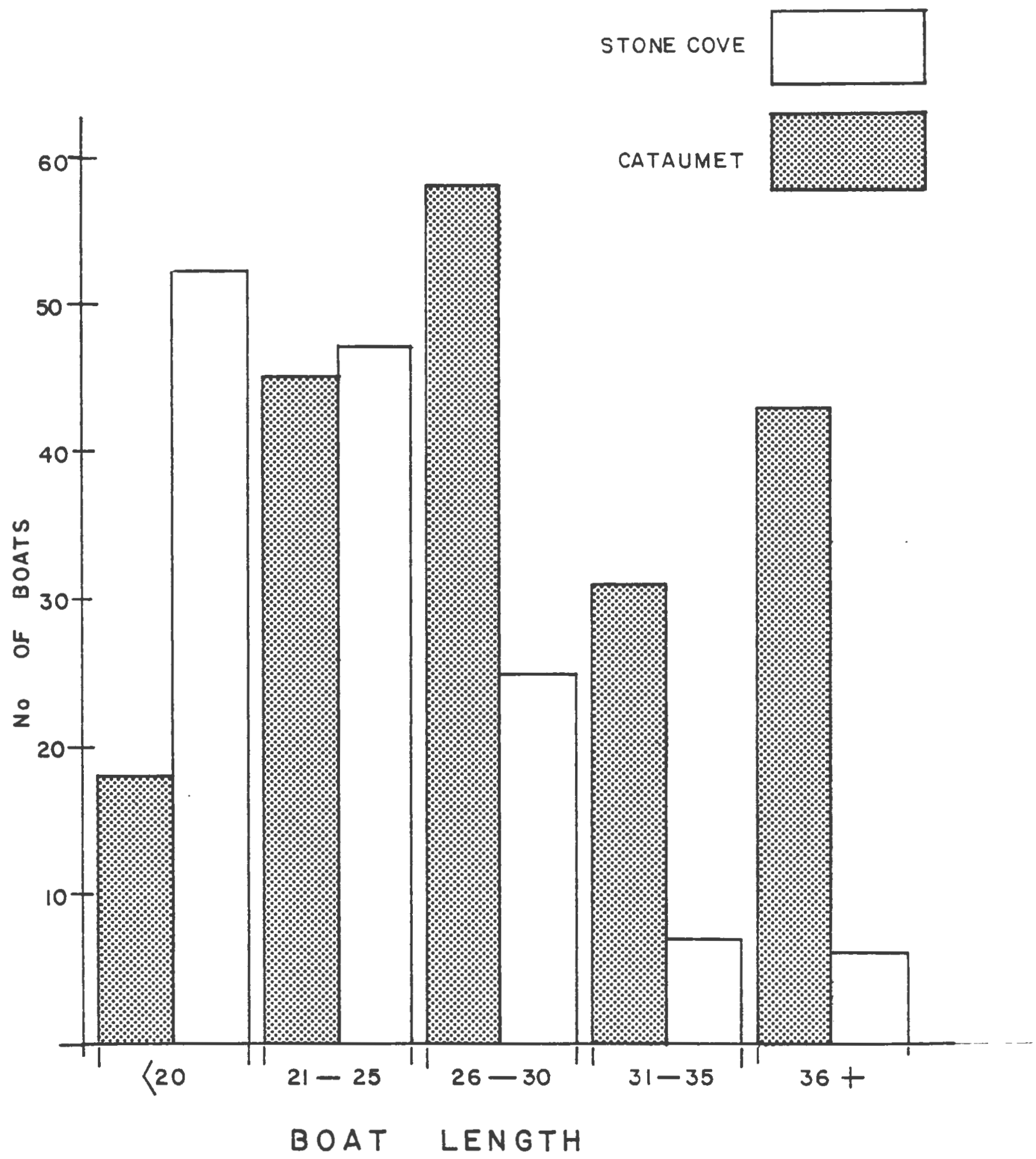


Figure P29

\section{DISTRIBUTION OF BOATS \\ BY LENGTH}

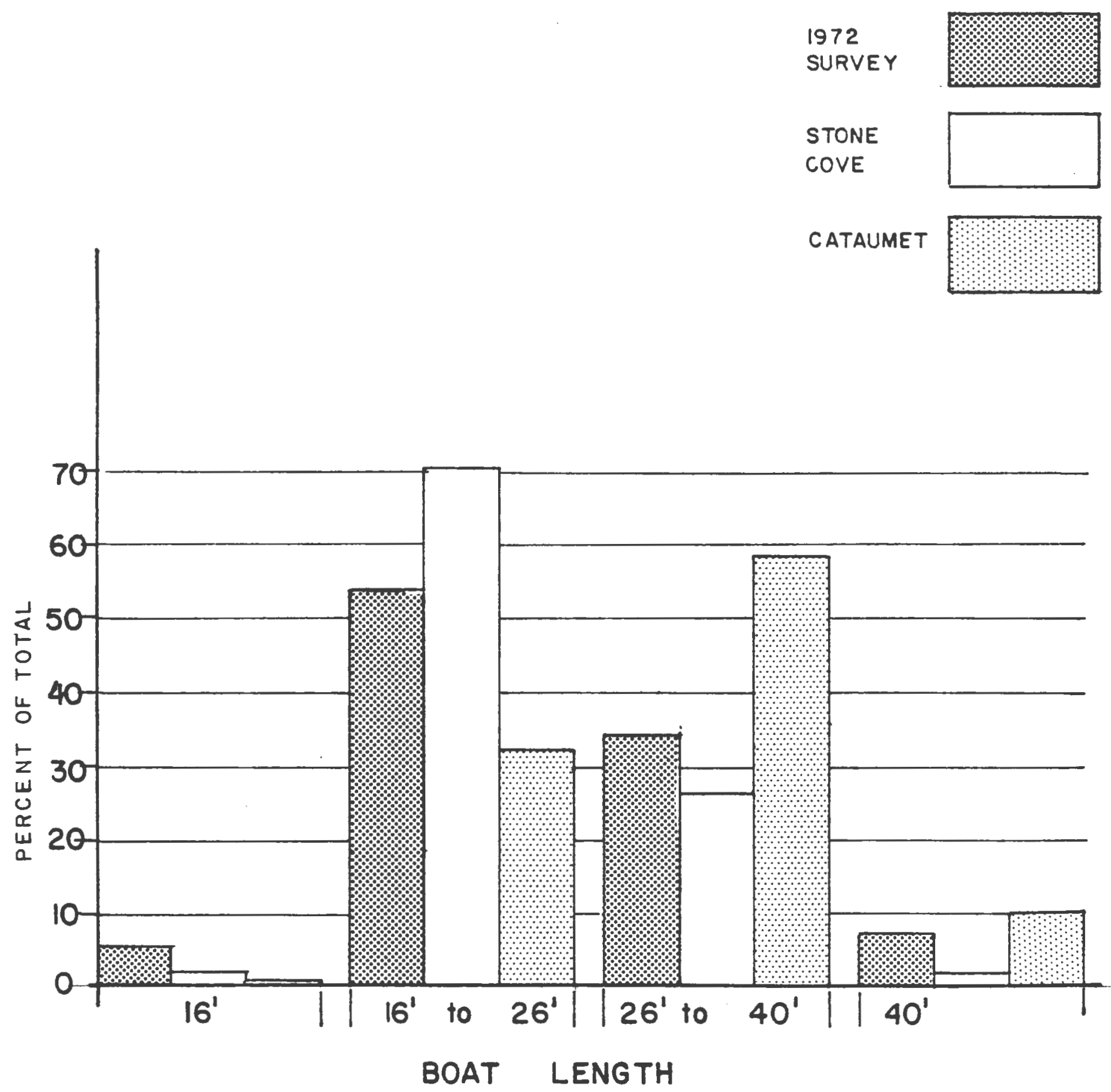


THE PLANING PBOCESS

Those who are faced with the creation of plans for the development of recreational boating facilities, very quickly discover that they are faced with dealing with a planning process wich systematically converts broad goals and objectives into measurable units of need which are further translated into specific physical requirements. This section of our study attempts to recreate the rational methodolcgy or planning process which was employed in the preparation of the development alternatives wich appear later in this report.

The advantages of this process are fairly numerous. First, it confitions its users to organize all of the individual needs of the project facility into a defensible package or program of requirements. Seccnd, and perhaps most important, the process is carried out before any physical solutions are implemented therebp giving the planner ample flexability and the opportunity to test those alternatives which best fit the physical needs of the facility. In other words, it establishes the maqutude and descripticn of the physical plant that is required to meet the operational needs of the array of the services that are to be offered to the patrons of the development.

In the case of marina planning, this process is seen as a six part series of steps. The combination of those steps is intonded to translate perceived needs into development 
alternatives within given parameters of available technology.

The sequential ccncept of the planning process may be better explained by a diagram (Figure T1).

To help amplify the diagran of this process, its principal elements are described as follows:

MARINA TECHNOLOGY - Marina technology is the study of the hardware that is available tc planners. The planning process dictates that the planner possess an intimate knowledge of the physical tools which are used to implement the development proposals. This is to say that the physical plant is composed of operational pieces or components which individually have certain strengths and weaknesses that influence the overall outcome of the plan.

PLANING CRITERIA - Planning criteria are the standards by wich one quantifies the use of the technology to fit specific situations. The ability to profect the physical needs of the functional activities is based on the fact that there is a direct relationsip between the type of services offered and the facilities that are required to house or othervie make those services possible. The details of this relationship are tied to a set of planning criteria wich estalishes in either numerical or spatial terms the physical requirements for all specified activities.

Planning criteria also involves the analysis of the functional relationships wich cccur between marina activities. With the helf of a matrix, as shown in Figure $T 2$, it is possible to identify the degree of dependence individual activities have on one another. In this example, we have 
characterized the functional ties between activities as limited to a choice amcng four types of relationships. Direct relationships are those in which the normal operation of the two activities is heavily dependent on direct physical contact between the two activities. Indirect relationships indicate that lirect contact is less essential and that an acceptable level of convenience is all that is necessary for optioum operation. Visual relaticnsips are those which do not depend on either direct cr indirect physical contact but rather benefit solely from mutual visibility. The converse of the a fore mentioned relationships occurs when a funtion constitutes a hazzardous or nuisance to another function. In this case, the matrix indicates what physical relationsips are to be a voider.

EXISTING CONDITIONS - The existing conditions at the warina site are of qreat imfortance tc the planner. A review of existing conditions quantifies the nature of the existing operation both from a functicnal point of view and a physical point of view in wich the surrounding environment is described.

op $ə r a t i o n a 11 \%$, this part of the study examines the marina, in order to inventory problems and deficiencies in its operation. Physically, the study of existing conditions documents the various environmental constraints and forces which influence marina design. The discussion of existing conditions is included in this report as two profiles of the case study marinas and their immediate surroundings. 
process prior to preparation of development alternatives is the confirmation of long range goals which will overcome the inherent deficiencies at the site. By comparing the development objectives with the planning criteria, the planner develops a progran of physical requirements which directly evolve into alternative design sclutions.

Bach of the components of the planning process are addressed separately in this section of the report. The actual establishment of development objectives and alternative design solutions of the two case study marinas will be covered in subsequent sections of the study. 


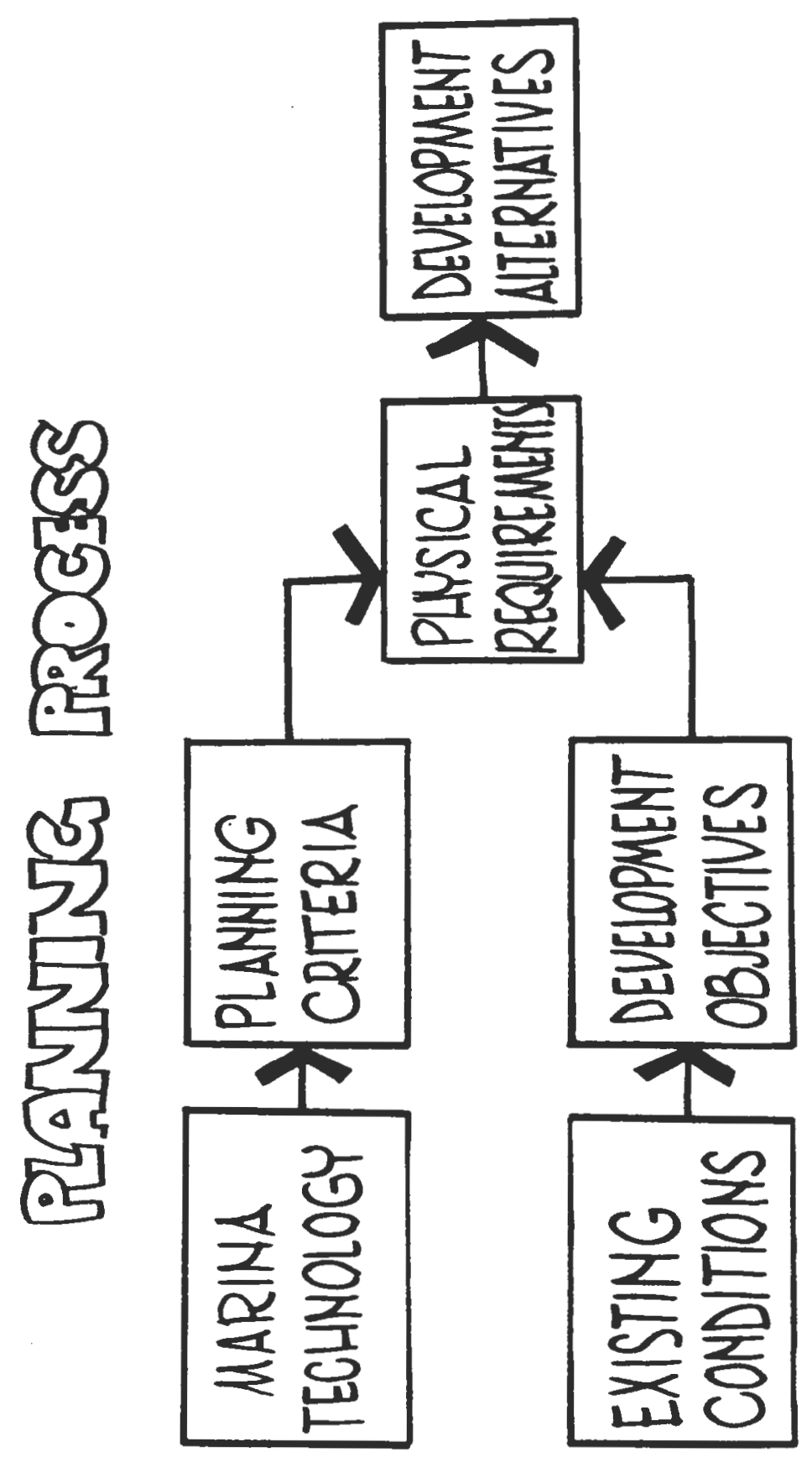




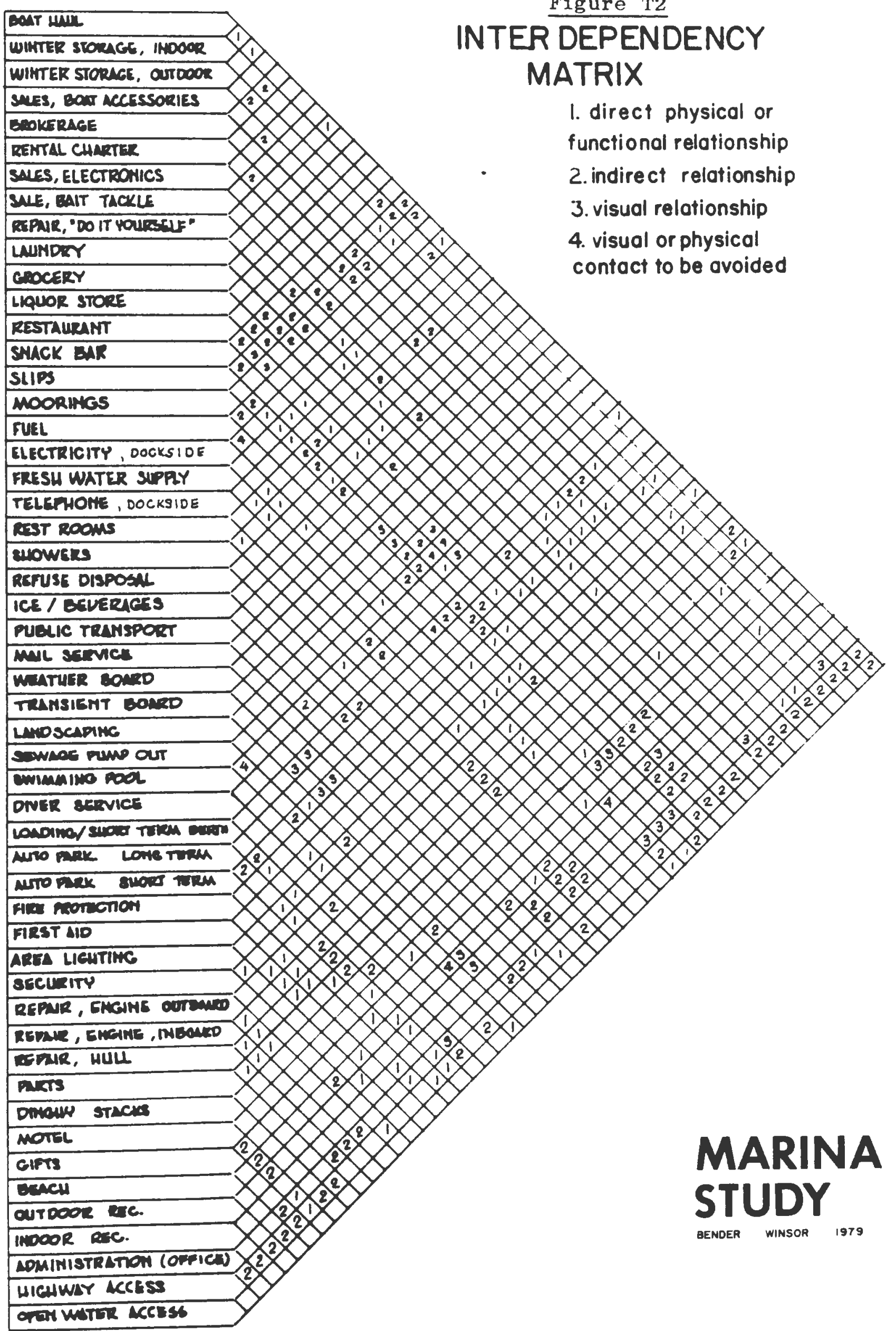




\section{THE PHYSICAL ELANT}

The discussion of the physical plant of recreational boatinq can be generally described as a composite of five principal components: 1. marina protection; 2. berthing and mooring: 3. shore facilities: 4. hoat hauling equipment and 5. miscellaneous equipment. By definition, the majority of boating installations that were inventoried in the Regional Perspective section included at least 4 of the 5 physical components. The only element wich had a measurable incidence of absence was boat hauling equipwent. Without any one of the other slements, the installation could not effectively function as a marina.

1. Marina Protection.

Probablp the most imfortant feature of small craft boating facilities is the provision of safe moorage and shelter. Historicallp. boaters have scught natural harbors of refuge. Unfortunately the demand for fleasure boating far exceeds the capacity of harbors whose principal protection is provided by the natural confiquration of the land. This has resulted in the creaticn of artifical harbors, with breakwaters, which is now a principal solution to the need for a calm natural 
environment. Even in natural harbors which provide a fairly hiqh deqree of frotecticn. there is the occasional boat owner for whom even moderate wave action is unacceptable. To satisfy these individuals, is is necessary to provide a more sophisticated and efficient breakwater system.

Breakwaters fall into two categories, those that are fixed and those that are constructed of flcating structures. The fixed structures, kncwn as the rubble mound breakwater, are constructed of larqe Iip-rap and sometimes armored with specially designed concrete shapes. These structures are desiqned to intercept and reflect incident waves, and they are usually effective against all conditions, providing that the waves are not sc larqe as to literally overrun the structure. Ploating breakwaters afford protection by a process of alternating the wave energy. Unlike fixed breakwaters, their cost is not appreciably affected by an increase in water depth or bottom conditions. They do have the disadvantage, hovever, of being ineffective against waves that are longer than twice the width of the structure (Herbich 6 Lou, 1977).

While a number of designs for floating breakwaters have been developed, cne of the mcst interesting and perhaps widely used is the floating scrap tire breakwater. originally developed by Goodyear Tire and Fubber company, this system uses scrap rubber tires lashed into a flcating blanket and anchored to the harbor bottom. Early versions of the system met with a number of problems particularly in regards to the methodology of connecting and lashing the tires. The materials used often decomposed from the chemical and physical properties of the 
environment. Recent innovations have led to the use of more durable materials and an improved level of success is expected. (Davis, 1977)

Floating systers have a distinct advantage over fixed breakwaters in that tidal flushing of the protected area is quaranteed. Pixed breakwaters, unless specifically designed to avoid tbe problem, can cause imfourdment of contaminated water. In adition, their presence often tends to upset local patterns of sedimentation and circulation causing siltation that could interfare with naviqation.

With the case study sites, both facilities are located in naturally protected harbors. However, under certain conditions the Buzzard's Bay marina is exposed to storm driven waves which penetrate the harbcr and can be effectively controlled by a floatinq system.

2. Berths and Moorings

The marinas and boating facilities observed in the coastal waters of Narraqansett Bay and Buzzard's Bay customarily are equipped with one or more of the techniques of berthing pleasure craft. The wethods include:

a. Yultiple tie up to fixed wharf or bulkhead.

b. Pixed dock and finger fiers.

c. Floating dock and finger pier.

d. Multiple tie up to fixed or floating dock without finger pier.

e. Dffshore moorings on peraanent anchors. 
A. Multiple tie up to permanent wharf or bulkhead.

This method is particularly comon in areas of high transiency where water area is severely limited. It is characterized by a permanent structural protrusion into the harbor zrea to which rleasure craft are secured parallel to the face of the structure. In congested ports, this method enables a relatively larqe number of craft to be berthed. However, this is accomplished at the expense of convenience on the part of the toat user. Those facilities which meet the general criteria as a marina normally do not rely on this type of facility except as an ancillary operation which is subordinate to a larqer complex of berthing facilites.

B. Fixed dock and finger piers

A fairly common method of berthing pleasure craft is the fixed dock and finger pier structure. In this system, one or more main docks, supported cn wocd or concrete piles, extends into the protected area. Boats are berthed alongside finger piers that are mounted perpendicular to the fixed dock. The Einqer piers can be cantilevered from the main dock, or, in the case of floating riers, attached in such a way as to allow tidal adjustment. Fixed docks are prone to ice damage in northern climates, but this aspect of their design can be overcome with aeration systers or propeller systems which prevent ice buildup arcund the supporting piles.

C. Ploating dock and finger piers

In this system, the entire dock system is supported on 
floatation devices with lateral bracing provided by piles and anchors. ploating systems are particularly valuable when bottom conditions and tidal range makes heavy fixed structures impractical. Many floating systems use pontoons for bouyancy with wooden decks ccnstructed over wood framing. Fiberglass structures supported on urethane foam blocks are also a common typo of fabrication.

A distinct advantage of floating systems over the permanent fixed systems is the degree of flexibility afforded to the marina operator. The geometry of floating systems of mcdular design $c a n$ be modified each season to adapt to fluctuations in user requirements, i.e., the cbserved trend to smaller boats, thereby raking better use of the space available.

D. Muliple tieup to fixed or floating dock without finger pier.

Berthing of pleasure craft along side docks with finger piers is a convenience that is not offered by all bcating facilities. In wany cases, the finger piers are absent altogether requiring that access be obtained directly frcm the main dock. Boats are secured, generally "stern to" with piles between the boat spaces for attachment of bow lines and to act as quides during the berthing frocess. obviously, by rewoving the finger piors, the maximum feasible number of boats berthed increases, but the level of convenience to the boater decreases. 
E. Offshore moorinqs on permanent anchors.

Probably the oldest method of securing small craft is with a permanent anchor or mooring. This method is still extremely popular as nearly 50 percent of all pleasure craft kept at marinas in Buzzard's Bay are on moorings. Obviously, the qreatest advantaqe to the offshore moorings is its cost. Compared with the expense cf constructing elaborate docks and piors, moorings are financially desirable, hovever, they lack tho level of convience to which boaters have become accustomed. This is a minor shortcoming that can be overcome by influencing boater attitudes and by providing support facilities, such as dinghy stacks, launch service, and service docks for short term tie ups and resupply work.

3. Shore facilities.

Dry land storage structures, often referred to as piqeon-hole storage or dry stack systems, have been in existence since the late 1960's. The system is patterned after the very ccmmon palletized warehouse storage in which products and palletized qoods are stacked in multiple layers in a steel rack. By adfusting the propcrtions of the rack to gain greater depth and width, the designers have been able to derelop a liqht weight structural grid capable of holding small craft from $14^{\circ}$ to $25^{\prime}$ in length. The key to the system is the mechanical placement or retrieval of boats from the system. Fork lifts with hyperextension masts can stack boats in four to five tiers. In storaqe systems with sufficient size to justify the cost, the lift system can be fully integrated into the 
systems with a hoist that is suspended from the protective buildinq structure.

In almost all cases the structural envelope for the rack system is a steel shell building. In larger facilities with an inteqrated lift system, the structure can overhang the water to allcw the lift to baul and store boats in one operation. The drystack system is fairly uncomon in New England waters with only one installation each in Narragansett and Buzzard's Bays. However, the potential for these structures is of some interest, as the average boat size and avilable land area are both declining.

4. Boat Hauling Equiptent

Pull service marinas which offer repair service and dry winter storage must also provide some means of hauling and launching boats as well as the capability to maneuver the boats to specified onshore locations. There is a wide range of equipment available for this purpose, but the methed and equipment employed is generally based on the size and weight charactoristics of the vessels and the operational characteristics of the marina cr boat yard, i.e., the location of rapair facilities and the provision of onshore winter storage.

A. Marine Railways - Marine railways are probably the oldest form of hauling and launching vessels. They have the advantaqe of qreat weight and size capacity and are usually mors suitable to the handing of large vessels which can justify their capital investment. Large commercial yards, 
which can afford the expense, integrate the launching railway with an elaborate rail transfer system which enables two directional lateral vovement of vessels. This type of facility, however, has little cr no relevance to recreational boating.

B. Marine elevators (Synchrolifts) - Marine elovators are sophisticated devices that incorporate a platform which is raised or lowered by motorized winches. The system, while capable of handing larqe vessels, has no inherent transfer ability and is, therefore, primarily used in gards with heavy repair emphasis. The elevators are actually small scale dry docks, and like dry docks, require vessels to remain in place until repairs are completed. To remove a vessel from the lift for transfer to a nother yard lccaticn reguires that the vessel be reriqged. i.e.. the cradles are exchanged for a trailer or other mobile equipment. This step makes them impractical for marina and yard operations that must launch or haul dozens of boats per dap. Its principal advantage is that large sail boats can be hauled for repairs or hull inspection without unstepping the mast.

C. Mono-rail hoist - Another launching/hauling device which requires a permanent installation is the over head mono-rail hoist. Boats are raised by a sling that is attached to an overhead hoist. The hoist is mounted on a steel rail system which provides the horizontal transfer capability. The principal advantaqe is that the device can handle large numers of boats in a short time. Its main disadvantage is that its weight and size capacity is severely limited and it is 
incapable of haulinq sail boats without first unstepping the mast.

D. Travelift - The Travelift is a completely mobile piece of equipment with both hauling and transfer capability. Constructed as two rectanqular frames mounted on rubber tires, the system straddles the vessel which is supported on lonqitudinal slinqs. Lifts with a removable lateral brace can accomodate sail boats with masts in place. They have the advantage of being able to handle a wide range of vessel sizes and weights with some capable of lifting and transporting boats of 40 to 50 tons. To effectively use a Travelift requires the installation of a permanent hoisting well, which consists of an indentation in a bulkhead which pernits a floating boat to be positioned under the lift. These machines are highly versatile and maneuverable with cnly two winor disadvantages. First, the span of the hoist, i.e., its wheel track, is the liniting factor in spacing boats for dry storage. Very often this results in a substantial percentage of the available ground area being lost tc the intervening spaces between roats. second, the height of the lift dictates the required opening size in storaqe buildings often forcing construction of buildings with eve beiqhts far in excess of that required by the boats themselves. However, the handling capacity of Travelifts (14 to 18 boats per day) makes them very attractive in the sense of operational efficiency.

E. Mobile and Fixed cranes - Many New England marinas rely on mobile cranes as a substitute for a rravelift. Boats are susponied by a spreader and sling system attached to the 
crane's cable and winch. Because the boom can reach beyond the bulkhead line, no sfecial hoisting well is required. A mobile crane is not as suitable to travelinq wile loaded as a Travelift but short distances over reasonable surfaces are possible. For lcnger distances with larqer boats it is usually necessry to load the bcat on a trailer for the transfer after which the crane is aqain used for final placement of the boat on a cradle. This necessity for double handing is obviously a disadvantage. Despite this limitation, the mobile crane is quite popular in that it can be put to more uses than launching and hauling boats. Those marinas with floating dock systems find mobile cranes particularly useful in the seasonal hauling of the dock secticns.

nithout the ability for horizontal movement, fixed cranes must roly cn other equifwent for yard transfer. Once hauled by a fixed crane, boats must be loaded on trailers for movemont within the yard. For yards with limited water space and an abundance of smaller sized vessels, a permanent fixed crane or fib boon is sometimes an adequate alternative to slips. In this example, small boats can be dry stored on private trailers and launched for a day's sail by the use of a crane mounted on the bulkhead.

F. Transfer Equipment - There are two pieces of equipment which are predominantly used for yard transfer vork. Trailers with weight capacities ranging from 3 to 15 tons are commony used in confuction with fixed or traveling cranes to complete the haulinq transfer system. In most cases the lifting ability of the crane is needed at both ends of the transfer operation, 
i.e. to load and unload the trailer. There are bydraulic trailers, however, that eliminate this requirement. High capacity trailers, when used with a launching ramp can also haul and launch boats without the assistance of a crane.

Fork lifts, an ingeneous breakthrough in the sciənce of material handlinq, are also beginning to appear in boat yard operations. Fork lifts are an essential part of dry stack storaqe (discussed in Boat stcrage Facilities) and with certain desiqn modifications, can be equipped with the capability to launch and haul boats from a bulkhead. For this use, the fork lift rails and chines are designed to be lowered below the roadway surface for distances of up to ten feet. In areas with little or no tide fluctuations, a fork lift can station itself on a bulkhead with its chines lowered and submerged below the draft depth of the vessel to be hauled. The boat is positioned over the forks, blocked, hauled and transferred to a dry storaqu location in che cperaticn (Figure T3).

5. Miscellaneous Dockside Equifuent

Boat cwners frequently judge the adequacy of a marina facility by the availability of certain conveniences and mechanical devices at dockside. A survey of consumer attitudes has injicated that most boat cwners are particularly concerned about the availability of such items as dockside electricity. water, ice, liqhting, telephcne and fuel. other systems such as sewage holding tank pump cut stations and fire extinguishing equipment are of special interest tc the coast Guard as well as the boating public. 
As for electrical equipwent, the most common dockside connections are as follows: 15 amps, 125rolts; 20 amp 125 volts; 20 amps, 250 volts; 30 amps, 125 volts; 30 amps, 250 volts: 50 amps, 125 volts; 50 amps, 250 volts. Dockside lighting is produced either by large area flood lamps and small walkway liqhts on stancheons located on the docks and finger piers. Hater is provided at most slips by a simple qarden hose attachment. Fuel, eitber diesel or gas, is sold at a separate fuel dispensing pier with protected feeder pipes leading back to onshore undergrcund storage tanks.

Some marinas now offer dockside telephone connections and this Eeature is increasinqly in demand in those areas where boat owners live aboard their boats for extended periods.

Another new feature appearing at warinas is the holding tank pump out device which takes treated waste from holding tanks and transfers it to a municipal sewerage system. As the dealine for ccrpliance with the holding tank regulations approaches, the interest in this equipment will undoubtedy increase. Unfortunately, the treated waste is detrimental to most municipal systems and definitely to onsite disposal systems, creating a strong disincentive for marina owners and the surcounding municipalities to offer this important service. All of these items of equipwent are of considerable importance to the rarina cwner wo is attempting to plan for and provide the most comprehensive and marketable array of user services. Some equifment is the first to be provided because of its relatively low initial cost. Dockside equipment, which is hiqh on the list of preferences of boat owners, is not often 
the first priority of a marina operator. The section concerninq marina facilities and their design criteria will describe further the dicrepancy between the boat owners' preference for dockside equifment and the marina operators' interest in offering that equipwent. 


\section{MAINA SERVICES}

In conjunction with the physical facilities are the services offered by uarinas. In order to provide services the appropriate physical equipment is needed, as discussed in the preceding secticn. But the equipnent is only one essential part of a marina operation. The manner in which the physicai plant is used makes a large difference in the level and scope of services provided. In addition, there are services which are basically indeperdent of physical requirements, such as weather information or brokerage services. This section deals with marinas from the point of view of the services provided. Generally, the authors feel that a diversity of services is desirable. Just as a natural ecosystem tends toward diversity as it matures, so too are marinas beconing more diverse with the passage of time. A modern marina is more than just a place to park boats: it has a carefully selected complementarity of services to offer. The charter operator benefits from having a sallmaker nearby, and vice versa, and the customer benefits from both. Just as cities benefit from the agglomeration effect of a concentration of goods and services, so does the modern marina.

Applying the planning process to the marina industry reveals similarities with other types of service delivery systems. There is little basic correlation between what the customers wart. what services are available, and what is most 
profitable. Tables 51 and 52 show lists of what customers felt they needed, what services were arailable, and what services were most profitable in two different surveys. The lists have all been arranged in order of highest to lowest percentage of response. Inspection of the lists shows little correlation. especially between what customers felt was important and what services were offered. There is a further problem illustrated with these lists, alsc typical of survey data for service delivery systems, in non-compatibility of the data categories. Table S1 contains data all accumulated from the same source, a NAEBM nationwide survey done in 1964 (Jones, 1964). The number two and number three priority items in the customer needs list are "water" and "ice". Yet these two categories are not to be found in the services offered survey. conversely, rest rooms are offered by $77 \%$ of the marinas, but customers were not asked about rest rooms. They were asked about showers, hovever, but again that does not appear in the services offerez list... and so forth. Iable 52 shows similar lists for marinas in Rhode Island, from surveys done in 1972 and 1973. The compatibility of customer needs versus services offered data is better in this table, but there are still seven services which were surveyed for availability, but not for consumer preference: (slips, area lighting, winter storage, haul/launch boats, boat/motor sales, brokerage, and sewage pumpout). It is important to note this limitaion, as it severely constrains attempts at statistical comparisons between the supply and demand for marina services. Table 33 shows services offered comparisons for the two case study activity areas, for both 
1977 and 1979. Customer preierence and profitability data were not available for these areas.

In order to further quantify the relationships between the various lists in Tables 51,52 , and 53 rank correlations were made between compatible data groups. These correlations are shown in Tables 54 through 510 . The statistical validity of these tables should be approached with extreme caution, due to the incompatibilities between survey data categories, as mentioned above. The correlation was made between data categories shared mutudlly by both lists being compared, often leaving out many of the highest ranking categories from both lists. This should be born in mira wher considering the correlation tactor. The alternative would have been to rank all categories in each list, and assign a zero value to the opposite list for its missing category. This was undesirable, as it would have reduced the correlation coefficient close enough to zero in most cases to renäer it meanirgless.

kendall's "tau" was chosen in preference to spearman's "rho" as the test statistic for two reasons. First, spearman's Rho is not able to deal with ranked data which are tied in score, and Kendall's Tau is (Kerda11, 1943; Korin, 1975; and Weiss, 1968). Second, Kendall's Tau calculations are easily available in computer programs. The "Statpack" package of the IBM 360 systems packages was used for the calcuiations shnwn nere. The two statistics are otherwise generally similar. varying between nogative cne for perfect inverse correlation, zero for no correlation, and positive one for perfect correlation. 
Tables 54 and 55 neke comparisons between needs and income data in Rhooe Island in 1972 and 1973 and the Nation in 1964. Tables 56, $\$ 7$ and 58 compare services otfered in Rhode Island in 1972/1973, the Nation in 1964, and the two activity areas in 1979. Tables 59 and 510 compare customer needs with services available in Fhode Island 1972/1973, and in the Nation in 1964. Table s4 shows a comparison between customar needs in 1972/1973 and 1964. The Tau of 0.800 is a high score, indicating a good correlation between customer needs at both times. A tentative conclusion is that customer needs haven't changed much during tho elansed time. However, the cateyories which are mutual to both lists are fairly basic, so this result is not unexpected. The exception is the "Social Activities" (listed as "Recreational Facilities" in 1964) category, which does not correspond well at a11. In 1973, social activities have become wuch more desirable, with $28 \%$ of the customers surveyed teeling that they are important.

Table 55 compares sources of income for the same two time periods, also having the high rau score of $0.80 n$. In the intervening time period, marine sales overtook slip rental as the highest grcss earner, bu+ the other categories remained ranked the same. Profitability data are unfortunately not available to make a similar comparison. If the profit ratio for slip rertal is still relatively high, there is a good likelibooi that slip rental may still be the biggest net earner.

Table S6 collpares the sezvices offered for the same two dates and areas as the previous two tables. The Tall of 0.597 
indicates a good correlation, hut there has also been some change, assulling that Bhode Islands marinas are fairly representative of the nation's as a whole in terms of services delivered. More conservatively, there are definite differences between the two samples. Winter storage, marine supplies, repairs, and boat/motor saies are all more available in the $1972 / 1973$ survey, but the percentage of available restaurants is much less. Table s7 compares services in thode Island in $1972 / 1973$ with available services in Narragansett Bay (essentially the same survey area) in 1979. The Tau is 0.783, a high score, but inspection shows that even though the services are generally ranked in the same order, the percent availability is mostly lower in 1979 than in $1972 / 1973$. The exception again, is restarunts at $24 \%$ in 1979, having more than doubled and now being very close to the national 1964 percentage.

Table S8 makes a 1979 service offered comparison between the two case study activity areas. Narragansett Bay and Buzzards Bay. The Tau is surprisingly low at 0.424 . This must be considered the most reliable of these comparisons in terms of data categories: they are completely compatible, having been compiled by the authors. Note, however that there are five tred numbers in the Buzzards Bay list and two in the Narragansett Bay list. The differences are, surprisingly, in the basic services and not in showers, restaurant, or laundromat availability. There is significantly lower availability of winter storage, dockside electricity, and marine supplies in Ruzzards Bay, and significantly higher 
availability of fuel. These and other differences in the activity areas are shown in slightly more detail in figure I1 in the Regional perspectives section. The average size of marinas in Euzzards Bay is smaller but the availability of indoor winter storage is much greater. These differences are discussed in more detail in the Regional perspective section, and the differences in the case study marinas reflective of these differences are discussed at the end of the Marina Profiles section.

The final two statitical comparisor tables, s9 and 510 , compare customer needs with avaliable services in the nation in 1964, and in Ehode Island 1972/1973. Table S9 has a low Tau of 0.400, and also suffers from data category incompatibility. with only five comparisons. Table S10, for Rhode Island in 1972/1973, has better compatibility but still a low Tau of 0.406. The implication is quite simply that there is not very good correlation between boat owners' service priorities and those of marina operators. The availability of 24 hour security stards out, witt $86 \%$ of the boat owners feeling it to be important, but on $1 y 26 \%$ of the marinas offering it.

These rank corrolations, despite their limitations, give support for the original statement that there is little relationship between the customers' preferred services, the marina's offered services, and the marina's economic best interest. The tables further indicate that basic customer needs haven't changed drastically between 1964 and 1973, nor has the money making base for marinas. There is a strong and definite difference between the two case study activity areas, 
in the level of basic services offered. There is a moderate difference in services offered in 1964 nationwide and in Rhode Island in 1973, but it is not possible to say on the basis of this data whether this is an indication of change over tine, or whether Rhode Island is different from the nation as it is different frch Buzzards Bay•

Using a compilation of these statistics, a general survey of the marina related literature, and informal "looking over" of numerous marinas, the list shown in Table s11 was developed. Marina services are grouped into three categories, "essential", "desirable". and "possible". Essential services are those considered basic to boats and people at a marina, on a concurrent level with such services in society at large. This includes such things as telephones, trash removal, first aid, etc. Which at first glance might not appear "essential". The second category, desirable, includes all those services which in most situations will be of benefit to both the boat owner and the marina operator allke. There is an admittedly tbin line between these two categories, and arguments can asily be made to shift many particular services from one to the other. The main purpose of this list is to prioritize allocation of space in the planning process, and to the extent that a facility cannot have a tennis court without the requisite parking (and hopefully showers), the list is legitimate. The three categories are the result of an initial attempt to prioritize the services, item by itam, which was found to be impractica 1 .

The third category, possible, simply represents other 
services which marinas in general do not have, but could be appropriate in certain situations. The list, after all consideration, stands or falls on common sense, which becomes the final criterion. The interdependency matrix discussed in the planning process section (Fioure $T 1$ ) is useful in organizing ore's common seuse to consider the relationship between the various services represented ir this list.

The only unusual items on the list are the Weather and Transient Boards. These are items which appear to be in demand by boat owners and are in very short supply. They consist of a chalk or cork board with daily weather information and messages and information for the transient boaters, who often have a communicatior problem with relatives or friends ashore or at home.

An attempt has been made to divide services into "primary" and "secondary" services, based on whether the service is for the boat or for the owner. onder this systen, a primary service is for the boat, and a secondary service for the onner. Just as in the "essential-desirable-possible" system, there is room for argument with the "primary-secondary" system, especially with regard to certair services. For example, is sewage pumpout a service for the boat or the owner? Despite this, the "primary-secondary" classification is valuable in combination with the "essential-desirable-possible" system. The combined systems are compiled in Table s12. Note that the primary services emerge mostiy in the essential section. only 6 of the 21 essential services are for the owners: telephone, rest roons, showers, ice/beverage machines, first aid, and area 
lighting. In the desirable category, 16 of the 25 services are secondary and in the possible categorv, all of the services are for the cwners. Under this schene, priorities for marina layout are as follows:

1) - Provide as many services for boats as possible:

2) - Provide services for owners at the same basic level as available in the local area (there is no need for a marina to be an uncivilized outpost):

3) - Provide additional secondary services only after primary services are available;

4) - Provide as mant "desirable" services as possible;

5) - Provide "possible" services only in unique situations.

These priorities have been used in the development of the case study scenarios, in order to have an orderly growth process during the course of marina development. 


\section{Figure S1}

COMPARISON TABLE:

CUSTOMER NEEDS, SERVICES OFFERED, PROFITABILITY

Al1 data from NAEBM, 1964, Nationwide basis

CUSTOMER NEEDS

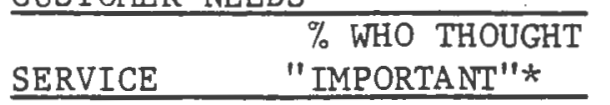

Fue 1

93.0

Water

89.5

Ice

71.7

Repairs, Maintenance

Tide, Weather Info

Electricity

Marine Supplies

Trash Collection

Auto Parking

Showers

Phone

Credit Card Use

Groceries

Restaurant

Bait, Tackle

Transportation

Laund ry, Laundromat

Mail Service

Sundries

Sleeping Accom.

Liquor Store

Swimming Pool

Lounge

Lockers

Bar

Housekeeping

Rec. Facilities

* Other responses were

"desirable","unimportant". Not shown here for reasons of clarity.

48.0

45.3

35.7

34.8

34.8

30.0

28.3

27.4

24.8

24.3

16.7

10.7

8.5

5.8

4.9

4.6

3.7

3.5

0.9

0.9

\begin{tabular}{|c|c|}
\hline & $\%$ OF MARINAS \\
\hline SERVICE & OFFER ING \\
\hline
\end{tabular}

Slips, Berths $\quad 100$

Haul, Launch Boats 77

Rest Rooms 77

Fue1 74

62.7 Winter Storage 70

61.4 Soft Drink Machine 70

52.2 Fishing: Bait, Tackle 67

Repairs, Service

Sales: Boats, Motors,

Supplies, etc. $\quad 50$

Rental/Charter $\quad 46$

Snack Bar 30

Restaurant 21

Grocery 5

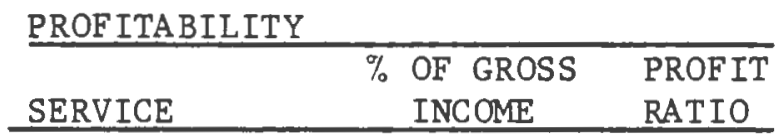

$\begin{array}{lrr}\text { Slip Rental } & 19.4 & 39.2 \\ \text { Sales, Marine Supplies } & 13.1 & 22.8 \\ \text { Repairs, Overhauls } & 11.7 & 26.7 \\ \text { Sales, New Boat/Motor } & 10.5 & 16.4 \\ \text { Petroleum Products } & 10.1 & 15.1 \\ \text { Winter Storage } & 10.0 & 27.4 \\ \text { Sales, Used Boat/Motor } & 8.2 & 8.8 \\ \text { Restaurant, Bar } & 4.4 & \text { na } \\ \text { Boat Rental } & 4.2 & 15.2 \\ \text { Bait, Tackle } & 3.7 & \text { na } \\ \text { Boatel Units } & 2.6 & 14.9 \\ \text { Grocery, Ice } & 2.1 & \text { na }\end{array}$

na $=$ not available

$\%$ of Gross Income $=$ amount in cents per total dollar taken in by marina

Profit Ratio $=\%$ net profit after deducting specific costs incurred by each service 
Figure S2

COMPARISON TABLE

CUSTOMER NEEDS, SERVICES OFFERED, \% OF GROSS INCOME

Rhode Is land, 1972 and 1973

CUSTOMER NEEDS, INBOARD SAIL AND PONER $\%$ WHO THOUGHT

SERVICE "IMPORTANT" *

\begin{tabular}{ll} 
SERVICES & OFFERED \\
\hline & $\%$ OF MARINAS \\
SERVICE & OFFERING \\
\hline
\end{tabular}

Fresh Water 87

24-hr Security 81

Electricity $\quad 78$

Fuel 78

Marine Supplies 70

Ice 66

Rest Rooms 65

Showers $\quad 48$

Restaurant $\quad 30$

Social Activities 28

Slips, Berths 91

Area Lighting 91

Winter Storage 86

Fresh Water 86

Electricity 83

Haul, Launch Boats 75

Marine Supplies $\quad 75$

Rest Rooms 75

Repairs 73

Ice 71

Gasoline 71

Boat, Motor Sales 70

Showers 43

24-hr. Security 26

Brokerage 20

Restaurant 10

Sewage Pumpout 0

Fue 1

24-hr. Security 69

Rest Rooms 62

Fresh Water $\quad 57$

Marine Supplies 48

Electriaity $\quad 45$

Ice 41

Restaurant 26

Showers 25

Social Activities 22

Source: Kelley \& Rorholm, 1974

SOURCE OF INC OME

\begin{tabular}{ll} 
& $\%$ OF GROSS \\
SERVICE & INCOME \\
\hline
\end{tabular}

Marine Store Sales $\quad 22.17$

Summer Dockage $\quad 21.42$

Repairs 20.01

Sales; Boats, Motors 10.47

Winter Storage $\quad 8.95$

Brokerage Fees $\quad 1.97$

Other 15.01

Source: Kelley \& Rorholm, 1974 
Figure S3

SERVICES OFFERED, STUDY ACTIVITY AREAS

NARRAGANSETT BAY

\begin{tabular}{lclc}
\multicolumn{1}{c}{1977} & & \multicolumn{2}{c}{1979} \\
\cline { 4 - 4 } SERVICE & $\begin{array}{l}\text { \% OF MARINAS } \\
\text { OFFERING }\end{array}$ & SERVICE & $\begin{array}{c}\% \text { OF MARINAS } \\
\text { OFFERING }\end{array}$ \\
\hline Electricity & 82 & Electricity & 85 \\
Rest Room & 77 & Rest Rooms & 81 \\
Repairs & 70 & Winter Storage & 70 \\
Winter Storage & 68 & Repairs & 70 \\
Fuel & 64 & Marine Supplies & 69 \\
Marine Supplies & 59 & Ice & 67 \\
Ice & 56 & Fuel & 63 \\
Showers & 30 & Showers & 33 \\
Restaurant, Snack & Bar & Restaurant, Snack Bar & 24 \\
Laundromat & 5 & Laundromat & 4 \\
\end{tabular}

BUZZARDS BAY

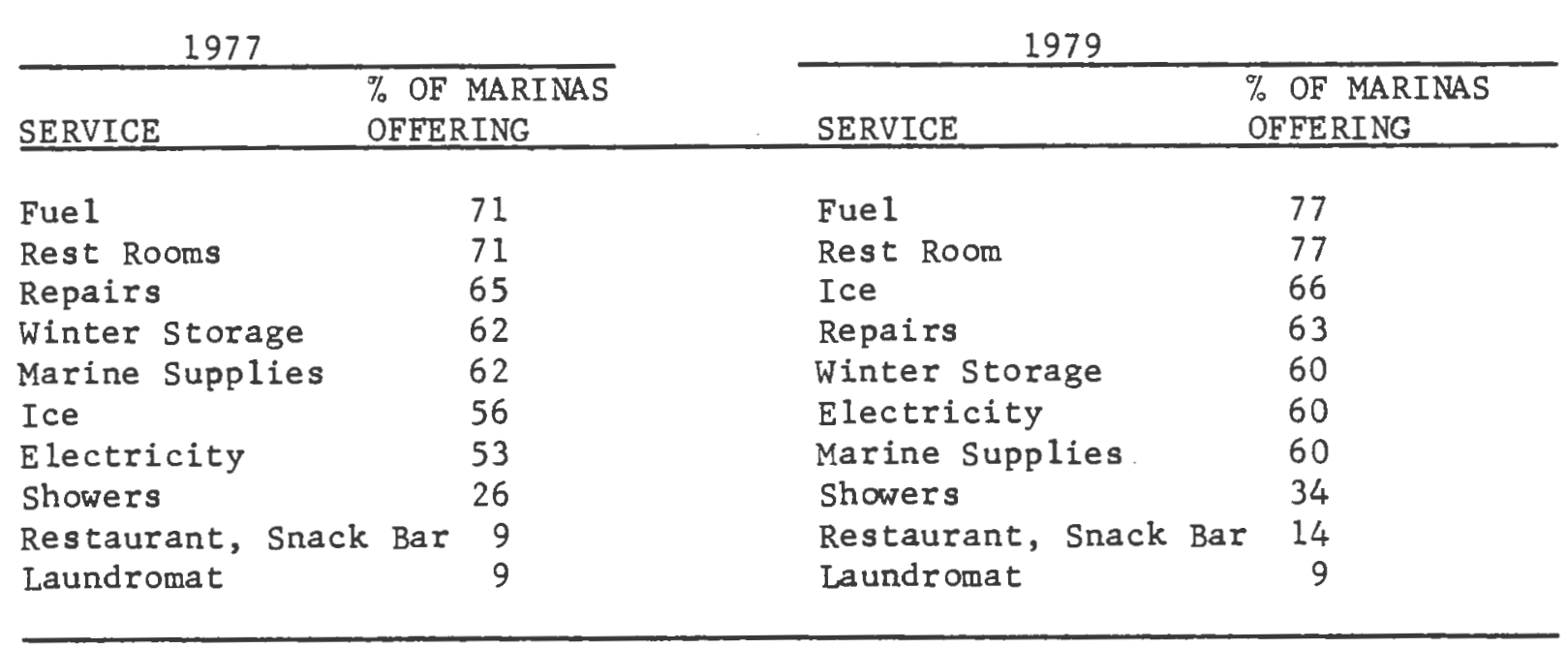

Source: Compiled from Boating Almanac, 1979 


\section{Figure 54}

\begin{tabular}{lcc}
\multicolumn{2}{c}{ CUSTOMER NEEDS COMPARISON - R. I. 1973 vs. Nation 1964} \\
Service & $\frac{\% \text { of customers how thought "important }}{\text { R.I. } 1973}$ & Nation 1964 \\
\hline Fresh Water & 87.0 & 89.5 \\
Electricity & 78.0 & 61.4 \\
Fuel & 78.0 & 93.0 \\
Marine Supplies & 70.0 & 52.2 \\
Ice & 66.0 & 71.7 \\
Showers & 48.0 & 35.7 \\
Restaurant & 30.0 & 28.3 \\
Social Activities & 28.0 & 0.9 \\
\hline
\end{tabular}

Correlation: $\mathrm{Tau}=0.800$

\section{Figure S5}

SOURCES OF INCOME COMPARISON - R.I. 1972 vs. Nation 1964

\begin{tabular}{lcc} 
& $\%$ of Gross Income & \\
\cline { 2 - 3 } Service & R.I. 1972 & Nation 1964 \\
\hline Marine Store Sales & 22.2 & 13.1 \\
Summer Dockage & 21.4 & 19.4 \\
Repairs & 20.0 & 11.7 \\
Boat, Motor Sales & 10.5 & 10.5 \\
Winter Storage & 9.0 & 10.0
\end{tabular}

Correlation: Tau $=0.800$ 
Figure $\mathrm{S6}$

SERVICES OFFERED COMPARISON - R.I. 1972 vs. Nation 1964

$\%$ of Marinas offering

\begin{tabular}{lcc} 
& $\%$ of Marinas offering & \\
\cline { 2 - 3 } Service & R. 1972 & Nation 1964 \\
Slips, Berths & 81 & 700 \\
Winter Storage & 75 & 77 \\
Haul, Launch Boats & 75 & 50 \\
Marine Supplies & 75 & 77 \\
Rest Rooms & 75 & 60 \\
Repairs & 73 & 74 \\
Fuel & 71 & 50 \\
Boat, Motor Sales & 70 & 21 \\
Restaurant & 10 &
\end{tabular}

Correlation: Tau $=0.597$

Figure S7

SERVICES OFFERED COMPARISON - R.I. 1972 vs. Narragansett Bay 1977

$\%$ of Marinas offering

\begin{tabular}{lcc} 
& $\%$ of Marinas Offering & \\
\cline { 2 - 3 } Service & 86 & Narragansett Bay 1979 \\
\hline Winter Storage & 83 & 70 \\
Electricity & 75 & 85 \\
Marine Supplies & 75 & 69 \\
Rest Rooms & 73 & 81 \\
Repairs & 71 & 70 \\
Ice & 71 & 67 \\
Fuel & 43 & 63 \\
Showers & 10 & 33 \\
Restaurant & & 24 \\
\hline
\end{tabular}

Correlation: $\mathrm{Tau}=0.783$ 
Figure 58

SERVICES OFFERED COMPARISON - Buzzards Bay 1979 vs. Narragansett Bay 1979

\% of Marinas offering

\begin{tabular}{lcc} 
Service & Buzzards Bay & Narragansett Bay \\
\hline Fuel & 77 & 63 \\
Rest Rooms & 77 & 81 \\
Ice. & 66 & 67 \\
Repairs & 63 & 70 \\
Winter Storage & 60 & 70 \\
Electricity & 60 & 85 \\
Marine Supplies & 60 & 69 \\
Showers & 34 & 33 \\
Restaurant, Snack Bar & 14 & 24 \\
Snack Bar & 9 & 4 \\
Laundromat & 9 & \\
\hline
\end{tabular}

Correlation: Tau $=0.424$ 
Figure S9

\begin{tabular}{|c|c|c|}
\hline Service & Needs $-\%$ & offered - \% \\
\hline Fue 1 & 93.0 & 74.0 \\
\hline Repairs & 65.9 & 60.0 \\
\hline Supplies Sales & 52.2 & 50.0 \\
\hline Groceries & 30.0 & 5.0 \\
\hline Bait, Tackle & 27.4 & 67.0 \\
\hline
\end{tabular}

Correlation: Tau $=0.400$

\section{Eigure 510}

Customer Needs vs. Services Offered - R.I. 1972, 1973

\begin{tabular}{lll} 
Service & Needs - $\%$ & Offered $-\%$ \\
\hline Fresh Water & 87 & 86 \\
24-hr Security & 81 & 26 \\
Electricity & 78 & 83 \\
Fuel & 78 & 71 \\
Marine Supplies & 70 & 75 \\
Ice & 66 & 71 \\
Rest Rooms & 65 & 75 \\
Showers & 48 & 43 \\
Restaurant & 30 & 10 \\
\hline
\end{tabular}

Correlation: Tau $=0.406$ 
Figure Sll

MARINA SERVICES

ESSENTIAL SERVICES

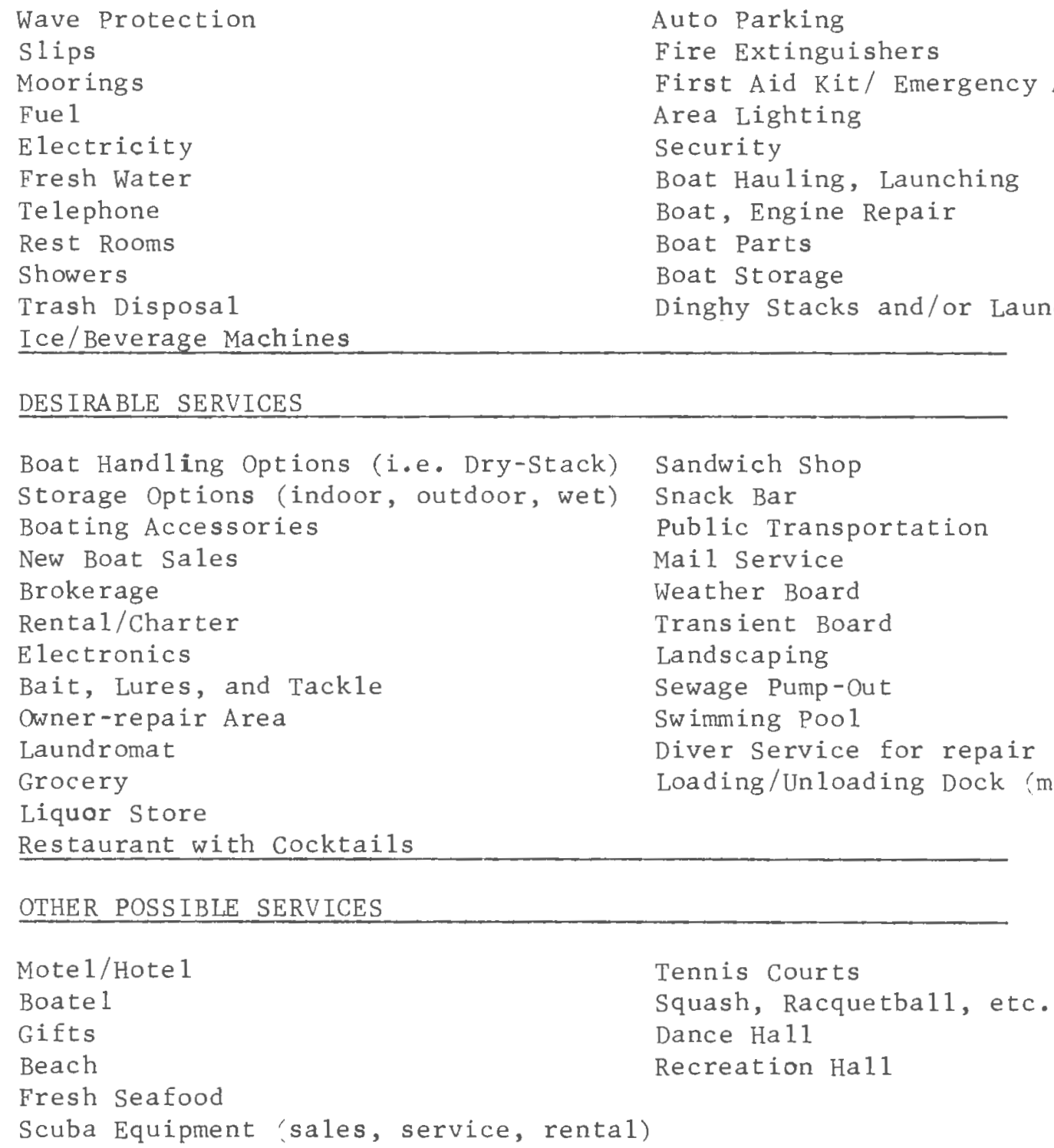


Figure $S 12$

MARINA SERVICES

ESSENTIAL SERVICES

\begin{tabular}{ll} 
PRIMARY & SECONDARY \\
\hline & \\
Wave Protection & Telephone \\
Slips & Rest Rooms \\
Moorings & Showers \\
Fuel & Area Lighting \\
Electricity & First Aid/ Emergency Ambulance \\
Fresh Water & Ice/Beverage Machines \\
Trash Disposal & \\
Auto Parking & \\
Eire Extinguishers & \\
Security & \\
Boat Hauling, Launching & \\
Boat, Engine Repair & \\
Boat Parts & \\
Boat Storage & \\
Dinghy Stacks \&/or Launch Service & \\
\end{tabular}

\section{DESIRABIE SERVICES}

\section{PR MMARY}

Boat Handing Options

Storage Options

New Boat Sales

Brokerage

Owner-Repair Area

Diver Service for Repair

Sail Loft
SECONDARY

Boating Accessories
Rental/Charter
Electronics
Bait, Lures and Tackle
Laundromat
Grocery
Liqour Store
Restaurant
Sandwich Shop
Snack Bar
Public Transportation
Mail Service
Weather Board
Transient Board
Landscaping
Sewage Pumpout
Swimming Pool

POSSIBIE SERVICES - al1 are secondary 
In order to put physical facilities into an optimal relationship for the dolivery of services, criteria are needed for the space requirements of the various service functions. These criteria are essential in converting theoretical desires into an actual site plan for a marina. Faced with a blank piece of paper, space criteria allow initial blocking in of areas required, in their correct proportions. In the instance of expansion of the case study marinas the criteria allow for expansion of the various functions in a coherent and logical manner.

For each of thes 3 criteria a range of space demands is considered. generally, there is a minimum, a maximum, and an "optimum" or median leval. For example, the number of Cadillacs which can be parked on an acre of land is considerably less than the number of volkswagens. In computing a numer to be used for space allocation purposes, a car size somewhat between the two would be assumed.

Six reference texts were found to be useful in deternining space requirements. Three of these texts dealt specifically with marinas, and were found to be best suited for space allocation of primary (boat related) services. The other three were standard planning and architecture texts, and were used for allocaticn of space for secondary services, and for other on-land area requirewents such as parking. It is beyond the 
scope of the present study to list in detail and explain specific requirements for each of the functional service areas, although the crucial elements will be discussed. Instead, a list of these references is iucluder here, for further consultation. The marina-related texts are:

$$
\begin{aligned}
& \text { Marinas: A Working Cuide to } \\
& \text { Their Development and Design } \\
& \text { (Adie, 1975) }
\end{aligned}
$$

Marinas: Recommendations for Design, Construction, and Maintenance (Chaney, 1961)

Small Craft Harbors: Design, Construction, and operation (Dunham and Finn, 1974)

The more general planning and design criteria texts are: The Community Builder's Handbook (Hckeever, 1968)

Urban Pläníng and Deságn Criteria (DeChiara and Koppelman, 1975)

Time Saver Standards for building Types (Lechiara and Callender, 1973) 
The chaney book, which is almost twenty years old, is in the process of being updated ard is due for publication during 1980 (Chamberlain, 1979).

The starting point for consideration of space reguirements is illustrated in figure A1, which shows a range of ratios for various general factors. of the five factors listed, two turned out to be crucial during our case study analysis: the car-to-boat ratio, and the density of cars per acre. It was found at both case study sites that the amount of land area available was the major constraint, not the amount of water. The amount of parking area available, in turn, was found to be the crucial constraint on the available land. The parking area is critical because the method used is as follows: For a given number of slips, (either in a new marina or in an expansion alternative), the required parking area to go with that number of slips is calculated. This area is then rultiplied by a factor of four to determine the overall area of 1 and necessary to support a full service marina with the given number of slips (Dunham and Finn, 1974:p.84). The required distribution of services is then allocated within this total land area. The initial determination of the parking area needed is thus very important, as any errors or misjudgements will be eccentuated by the factor of four.

In Figure A1, the ratio of parking spaces per slip varies from one-half parking space per slip to two full parking spaces per slip. These are the ranges cited in the handbooks. An informal survey of local Narragansett Bay marinas revealed a similar range of parking space requirements among the marina 
operators. That is, in response to questions about how many parking spaces were required per slip, the answers ranged from one-half to two. The reasoning was genelally that on a peak day (fourth of July, for example) fifty to seventy five percent of the boats at a given marina would go out. A substantial porticn of boat owners bring guests, who often arrive in a separate car. Since all the nwners are not likely to be at the marina at once, even on a peak day, one parking space per boat was felt to be more than adequate, even for guests. On the other hand, one-half space per boat was not felt to be enough, especially if there was a restaurant sharing parking with the boatowners. Bearing this in mind, for the purposes of the case studies presented here, a ratio of three parking spaces per four slins, or 0.75 to one, was used for the calculations. This also agrees with the source of the "four times" factor for overall use (Dunham and Finn, 1974:p.84). As this is being typed (December, 1979), new evidence from aerial photography is available indicating that even on peak days one-half space per slip is sufficient (Ross, 1979. Collins and sedgrick, 1979). Future calculations should probably use this figure rather than anything greater.

Most marinas with outdoor winter storage do not have a parking problem; the yard space used for storage can be used for parking during the summer season. However, as modernization or expansion takes place, the need to define different parking areas for different uses arises. A restaurant will need sufficient short-term parking to accomodate mealtime peaks. A boat owner setting out on a 
week-long cruise will need a short-term loading/unluading area, to transfer supplies trom car to boat, and then will need a long term parkıng area with 24-hour security, to leave his car safely while he is gone.

As the rarina becomes more efficient in terms of the numbers of boaters it can serve, it must also become more efficient in terms of formal designation of parking. Having determined the number of spaces needed, as a ratio to the number of slips, the next step is to determine how unch space is needed for a given number of parking places. The marina texts generally assume that 90 or 100 cars can be parked in one acre. The planning texts disagree, and qive a more detailed analysis. In general, for a well planned parking lot, 100 to 155 cars can be accomodated. These figures include space for entry and exit as well as parking (Dechiara and Callender, 1973). Angle parking, currently popular with some dock designers, has been shown in automobile parking designs to be less efficient in terms of space utilization, when compared to right angle parking, and the same holds true for boats. Angle parking should only be considered, either on land or in the water, where a narron strip of space which is otherwise unusable is all that is available. The increased ease of access of angle parking allows for a narrower overall space for automobile maneuvering, but that ease of maneuvering does not extend into the water: automobiles do not have to contend with waves, winds, currents, or screw torque while in reverse. Automobile parking is also the crucial space limiting factor when considering rack storage. For example, a 10,000 
square foot rack storage building will hold about 100 boats if four tiers are used. Using a parking rate of 125 cars per acre (which is moderate, between the 100 and 155 car-per-acre extremes). the parking area required is larger than the area for the building. With one-half parking space per slip approximately 17,400 square feet are needed for the facility, and with 0.75 spaces pez boat the parking area is approximately 26,100 square feet. In the latter case, 36,000 square feet are needed for the facility, about 0.83 acre. In addition, the four times factor inust be applied to the parking requirement, to keep the proper proportions for a full service marina. Since 26,100 square feet is equal to 0.60 acres, the total area for expansion is 2.4 acres - quite a bit morc than intuitive consideration would indicate for a 10,000 square foot building. At one-half parking space per boat, the rack storage facility still needs 1.6 acres of land to support it. of this 1.6 acres, the building itself takes up only 0.23 acres. Note that the change from 2.4 to 1.6 acres, occasioned by the change from 0.75 to 0.5 parking spaces per boat, is a change of 0.8 acres per 100 boats in overall land requirements. This emphasizes the need for careful initial assumptions in the space allocation process.

once the overall area requirements have been determined. the next step is to portion out space among the various functions. Certain functions inst be considered separately. for a variety of reasons. A large restaurant, for example, must depend on a ccnsumer market area which may be different 
from the market area of $t h \in$ marina. The Chart Room restaurant at Cataumet Marina is a case in point. Many of the boat owners drive for over an hour to reach the marina, but not many people will drive from Boston to Cape cod just for dinner. These different markets for th different furctions must be considered when allocatino space at a yiven site. other functions are linited in space requirements by simple physical limitations. For example, public restrooms require a minimum of about 500 square feet for an ddequate facility able to serve more than one customer of each sex at a time. For the sake of the ambient water quality, and soon for legal reasons, boat owners must not use their heads while in the marina. Yet the marina industry as a whole has a poor record in providing rest rooms: not many are a nice place in which to brush one's teeth. In recommentations for oxpansion, this minimum space standard must be recognized. At the other end of the scale, few marinas, no matter how large, need more than 5,000 square feet for service facilities. With these types of limitations in mind, a genetal table of space allocation ratios was jeveloped, and is shown in Pigure A2. The purpose of the table is to give numbers to initial space requirements, given a certain number of boats. The figure is in the form of two columns. The first shows the average number of square feet allocated for each of the services listed. The averages were taken from a survey of six large marinas, ranging in size from 230 to 735 boats (Chaney. 1961). In order to find a relatively large (in terms of square feet) service to serve as a key, the classification of "total service" area was formed. Total service area 
consists of hull repair, Luboard engine repair, and outboard engine repair. The average number of square feet for $t$ his classification was 4,375. This number was taken as unity, and the proportion of ary given service to total service was calculated as a ratio between zero and one. mhese ratios are shoun in column two. For example, the average amount of office space in the marinas surveged was 425 square feet, about one tenth of the total service area. The ratio for office space is thus 0.10, and similar procedures nave been followed for the other service catogories. The total service area is determined for a given scenario, and the other services are allocated space proportionately. Always in mind are the constraints for any one service. Restrooms are not allowed to become too small, and hull service is not allowed to become too big, and so forth. Final deteranations are tiade incrementally, as physical, economic, social, and environmental limitations become more inportant as the site plan develops and matures.

In order to figure the relative etficiency of slip distribution, and to calculate the amount of space needed for winter storage, a simple methodology for figuring the average area requirement per boat was developed. The length and beam for five length classes were determined (Dunham and Firn, 1974), and the area of the rectangle occupied by a theoretically rectariqular boat for each length class was calculated. This is shown in figure $A 3$ as the inner rectangle. An envelope, "E", of valying thickness was allowed around the boat to coupensate for different densities of in-water and 
on-land storage. The calculations were then redone for each of the envelcpes, and as shown in the four right-hand colums, an envelope of 2 feet has a substantial amount of area, while an envelope of four feet has as much area or more than the boat itself (except for the largest length class). A 35 foot boat takes up about 420 square feet, but with an $\in$ Ivelope of four feet takes up 860 square feet. The ervelope is thus 440 square feet, more space than the boat. If maximum density of boats per unit arta is desired, the size of the envelope, and the resulting buffer space, is critical.

Boats are not, of course, usually rectangular. Nor is it $\mathrm{n}$ acessary in a long line of right-angle spaces to duplicate the buffer spaces between boats, so the envelope spaces would double up along the sides. This reduces the size of the envelope by one side per boat (broady, about one-third), and makes a difference in comparing different finger pier sizes and finger fier versus no-finger-pier options. It is also common during winter storage to put boats together in a jigsaw fasnion, bow alongside bow, leaving little or no space between them, in order to fill an irregularly shaped storage area with the maximum number of boats. In that case, of course, this method does not apply. If a Iravelift is used, the beam of the Travelift becomes the limiting factor.

The numbers shown in Figure 83 form the basis for some useful calculations concerning the average space requirements for a given marina. These calculations have betr done for the two case study marinas, and are shown in Fidures A4 and A5. The object is to deterine, aiven various space envelopes, how 
much of the marina acreage is actually occupied by the boats themselves.

The distribution of boats by size was discussed in the comparison of the two case study marinas, and is shown in each of these space requirement fiqures in the column marked "\%". For each of the different envelopes are two columns. The first is the square feet for the given length class and envelope as figured in table A3. The second is the product of the percent factor and the square feet, a number which is used to calculate a weighted mean. The mean is shown at the bottom as the square feet, AVERAGE, per boat. This in turn is multiplied by the number of boats at $t h e$ marina, giving, for each envelope, the total amount of space occupied by boats at the marina.

The methodologies discussed in this section were used to construct, and then +c compare, the scenarios for each case study marina. The applications of these are found in the scenarios section, where the space requirements have been determined and compared for a variety of levels of expansion. 
Figure A1

GENERAL SPACE REQUIREMENT RATIOS

\begin{abstract}
Land to Water Ratio
Density of Boats per Acre

Car to Boat Ratio

Density of cars per Acre

Persons to Boats Ratio
\end{abstract}

$\begin{array}{ll}1: 1 & 2: 1 \\ 25 & 65 \\ \frac{1}{2}: 1 & 2: 1 \\ 100 & 155 \\ 1.5: 1 & 3: 1\end{array}$




\section{Figure A2}

\section{SPACE REQUIRED FOR SELECTED SERVICES}

From Chaney, 1961, survey of six large marinas

Average 作 of Boats was $=392$, minimum $=230$, maximum $=735$

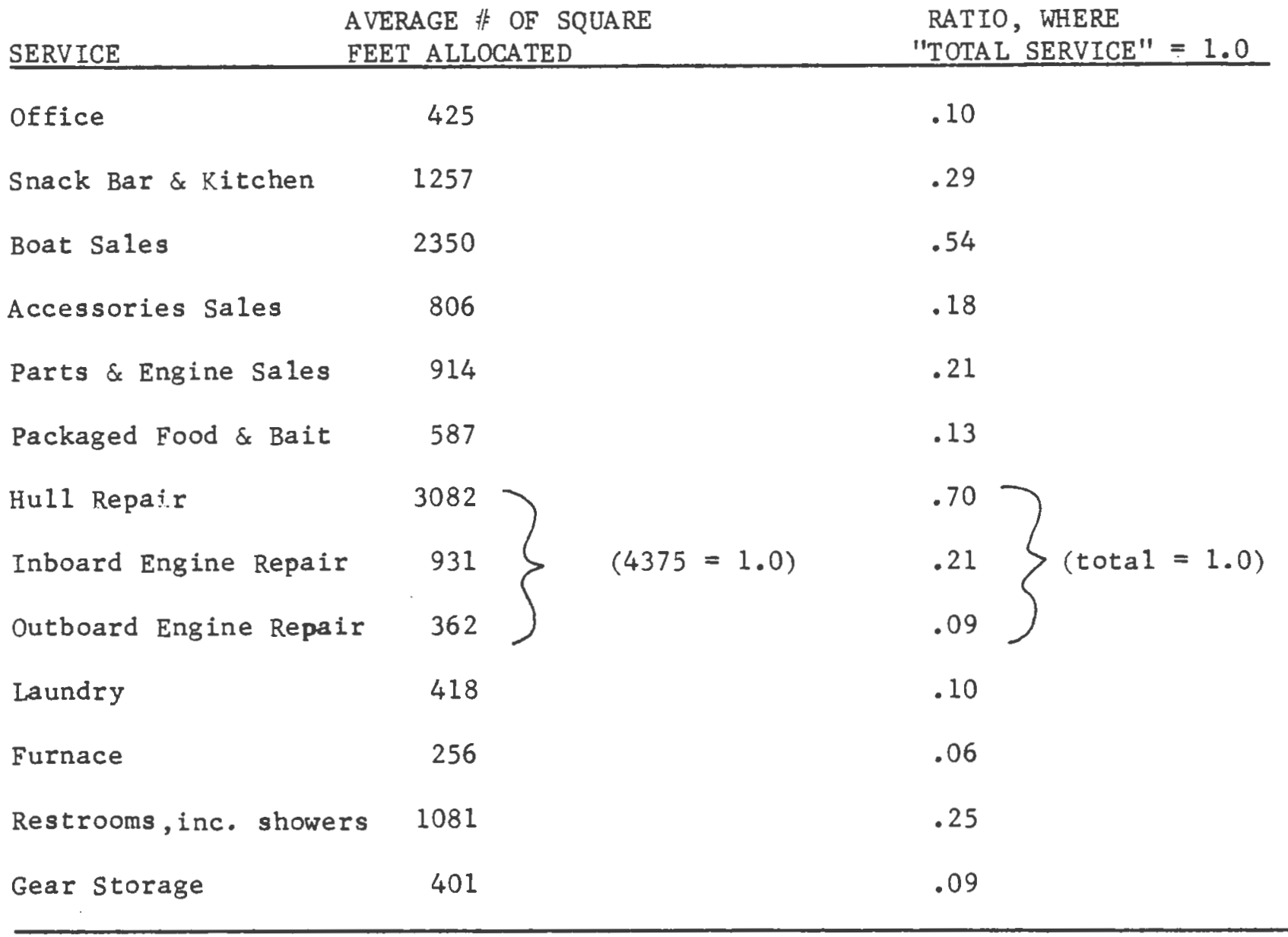

"total service" = hull repair + inboard engine repair + outboard engine repair 
Figure A3

SPATIAL REQUIREMENTS OF BOATS

Inner rectangle represents

the area required by the

length and beam of the boat.

The envelope, "E", is a buffer

distance between boats which

is variable. In the table below

"E" is specified as the width

of the perimeter strip.

Square Feet per Boat, With Envelope of: $E=$

Square Feet per Boat

6"

11

2'

$4^{\prime}$

$\begin{array}{llll}\text { Up to } 20^{\prime} & 20 & 8 & 160 \\ 21^{\prime}-25^{\prime} & 25 & 10 & 250 \\ 26^{\prime}-30^{\prime} & 30 & 11 & 330 \\ 31^{\prime}-35^{\prime} & 35 & 12 & 420 \\ 36^{\prime} \text { and over } & 45 & 14 & 630\end{array}$

189

$286 \quad 324 \quad 406$

594

$\begin{array}{llll}372 & 416 & 510 & 722\end{array}$

$\begin{array}{llll}468 & 518 & 624 & 860\end{array}$

$\begin{array}{llll}690 & 752 & 882 & 1166\end{array}$ 


\section{CALCULATED SPACE REQUIREMENTS - STONE COVE}

\begin{tabular}{|c|c|c|c|c|c|c|c|c|c|c|c|}
\hline & & $E=$ & 0 & \multicolumn{2}{|r|}{$6^{\prime \prime}$} & \multicolumn{2}{|r|}{$1^{\prime}$} & \multicolumn{2}{|r|}{$2^{\prime}$} & \multicolumn{2}{|r|}{$4^{\prime}$} \\
\hline LENGTH CLASS & $\%$ & $\mathrm{ft}^{2}$ & $\mathrm{ft}^{2} \times \%$ & $\mathrm{ft}^{2}$ & $\mathrm{ft}^{2} \times \%$ & $\mathrm{ft}^{2}$ & $\mathrm{ft}^{2} \times \%$ & $\mathrm{ft}^{2}$ & $\mathrm{ft}^{2} \times \%$ & $\mathrm{ft}^{2}$ & $\mathrm{ft}^{2} \times \%$ \\
\hline Up to $20^{\prime}$ & .39 & 160 & 62.4 & 189 & 73.7 & 220 & 85.8 & 288 & 112.3 & 448 & 174.7 \\
\hline $21^{\prime}$ to $25^{\prime}$ & .35 & 250 & 87.5 & 286 & 100.1 & 324 & 113.4 & 406 & 142.1 & 594 & 207.9 \\
\hline $26^{\prime}$ to $30^{\prime}$ & .18 & 330 & 59.4 & 372 & 67.0 & 416 & 74.9 & 510 & 91.8 & 722 & 130.0 \\
\hline $31^{\prime}$ to $35^{\prime}$ & .05 & 420 & 21.0 & 468 & 23.4 & 518 & 25.9 & 624 & 31.2 & 860 & 43.0 \\
\hline $36^{\prime}$ and over & .04 & 630 & 25.2 & 690 & 27.6 & 752 & 30.1 & 882 & 35.3 & 1,166 & 46.6 \\
\hline $\mathrm{ft}^{2}$, AVERAGE & per boat: & & 255.5 & & 291.8 & & 330.1 & & 412.7 & & 602.2 \\
\hline 137 Boats & es tota & 8 & re feet & & & & & & & & \\
\hline $\mathrm{ft}^{2}$, TOTAL: & & &, 000 & & 9,980 & &, 220 & &, 540 & &, 500 \\
\hline ACRES : & & & 0.80 & & 0.92 & & 1.04 & & 1.30 & & 1.89 \\
\hline
\end{tabular}




\section{CALCULATED SPACE REQUIREMENTS - CATAUMET}

\begin{tabular}{|c|c|c|c|c|c|c|c|c|c|c|c|}
\hline & & $E=$ & 0 & & 6" & & $1^{\prime}$ & & $2^{\prime}$ & & $4^{\prime}$ \\
\hline LENGTH CLASS & $\%$ & $f t^{2}$ & $f t^{2} \times \%$ & $\mathrm{ft}^{2}$ & $\mathrm{ft}^{2} \times \%$ & $\mathrm{ft}^{2}$ & $\mathrm{ft}^{2} \times \%$ & $\mathrm{ft}^{2}$ & $\mathrm{ft}^{2} \times \%$ & $\mathrm{ft}^{2}$ & $\mathrm{ft}^{2} \times \%$ \\
\hline Up to $20^{\prime}$ & .09 & 160 & 14.4 & 189 & 17.0 & 220 & 19.8 & 288 & 25.9 & 448 & 40.3 \\
\hline $21^{\prime}$ to $25^{\prime}$ & .23 & 250 & 57.5 & 286 & 65.8 & 324 & 74.5 & 406 & 93.4 & 594 & 136.6 \\
\hline $26^{\prime}$ to $30^{\prime}$ & .30 & 330 & 99.0 & 372 & 111.6 & 416 & 124.8 & 510 & 153.0 & 722 & 216.6 \\
\hline $31^{\prime}$ to $36^{\prime}$ & .16 & 420 & 67.2 & 468 & 74.9 & 518 & 82.9 & 624 & 99.8 & 860 & 137.6 \\
\hline $36^{\prime}$ and over & .22 & 630 & 138.6 & 690 & 151.8 & 752 & 165.4 & 882 & 194.0 & 1,166 & 256.5 \\
\hline $\mathrm{ft}^{2}$, AVERAGE & er $b$ & & 376.7 & & 421.1 & & 469.4 & & 566.1 & & 787.6 \\
\hline$f t^{2}$, TOTAL: & & &, 460 & &, 120 & &, 143 & & 0,390 & &, 582 \\
\hline ACRES : & & & 1.69 & & 1.89 & & 2.09 & & 2.53 & & 3.53 \\
\hline
\end{tabular}


DESCRIPTION OF DEVELOPMENT ALTERNATIVES

STONE COVE MARINA

The development scenarios for stone cove marina are based on the fulfillment of four main objectives: 1. To enhance the aesthetic and general appearance of the area, 2. To expand the capacity of the facility, 3. To improve its operational efficiency and 4. To expand the retail sales operation.

These objectives may seem somewhat over simplified but the fact of the matter is that to achieve the broad goal of establishing a full service marina at stone cove, it is necessary to specify the substantive objectives as described above.

The scenarios that follow are the design alternatives which are proposed as the means of fulfilling these objectives. In general, the scenarios are presented in an order of increasing complexity and cost. The first alternative is the most conservative and as such, proposes the fewest modifications to the existing marina.

The critical determinant in all of the alternatives is the amount of land area which can be dedicated to onshore activities, particularly customer parking, as voll as indoor and outdoor service functions.

While the principal objective is to develop more slips for a greater capacity. these slips cannot bo supported by onshore 
activity unless sufficient land area is available, All of the proposals attempt to strike a balance between available land, spatial requirements of shore facilities and the expansion of berthing capacity. The strong relationship between these three factors is illustrated buy Figures s1-1, s1-2, and s1-3.

The second major consideration in devising these proposals is the array of boat sizes that is likely to be attracted to the expanded marina. Several assumptions have been formed on the question, the first being that there is a pronounced tendency toward smaller boats in boating activity areas. The number of boats in the size class that is 25 feet in length or less is expected to increase in proportion to the total flett at the marina. The second assumption is that the present ratio between the various boat length classes, when adjusted for the increased demand in the small boat category. will hold constant over time. The proposed frequency distribution of boat sizes is shown in Figure s1-2 along with a description of the slips that are recommended to accommodate the growing fleet.

In conjunction with the allocation of land and the estimation of future berthing capaci+y, there is the development of spatial requirements for onshore functions which correspond with the level of waterborn activity. Figure s1-3 illustrates this pattorn of the increase in physical requirements as the berthing capacity of the marina increases. The existing site configuration allows for approximately 0.6 acres of vehicle parking which is estimated to provide slightly less than 72 parking spaces (Figure s1-4). At a ratio of 07. parking spaces per slip, the land that is under direct 
control of the marina can only support slightly more than 100 slips. Fortunately, the neighboring public parking area is capable of augmenting the marina's parking capacity to meet its present size of 137 slips. Any expansion of this capacity. however, dictates that the parking area be included in a 11 land area calculations as a permanent addition to the parking capacity.

In scenario 1a (Figure $51-5)$, this additional parking will allow for the construction of 33 slips in the shallow cove to the east of the existing facility increasing its capacity to 170 boats. The total land under the direct control of the marina would then become 3.93 acres. An existing dock structure (F), and finger piers (D) will be relocated within the cove to facilitate the new slips which are positioned at the perimeter of the cove. The existing service and retail structure is to be replaced by a new two story 5,770 square foot building located in approximately the same location as the oriqinal structure (A) $\&$ (B). The sales and administration functions will be located in the second floor but with on qrade access to the frontage road to the north. Taking advantage of the steep slope that separates the frontage road from the yard work area, the service functions on the lower level will also have on grade access to the yard work area.

other general improvements which are required by this alternative include the dredging of approximately 0.3 acres of the shallow cove to increase its depth by one to three feet. In addition, the yard work area which is expected to recoive the greatest amount of traific will be surfaced with asphaltic 
concrete.

Scenario $1 \mathrm{~b}$ (Fiqure $S 1-6$ ) is based on the same assumptions as $1 a, i, e .$, that the public parking area wijl be available for marira use giving the facility the additional parking spaces needed for expanded berthing. In this alternative, however, the additional berthing capacity is provided by removing the finger piers frol docks (P) and (D) for an additional 43 boats. The removal of the finger piers effectively reduces the beam spacing requirements of hoats thereby increasing the number of vessels which can be secured to a floating or fixed pier, As can be seen by Figure s1-6, this proposal encourages the addition of boats that are unjer 30 feet in length with the majority being 25 feet or less. This is consistent with our findings that boat ownership trends are favoring this class over the larger more expensive vessels. No other structural alterations are requiren otber than the construction of a new service building.

Certainly, this alternative provjdes tho greatest level of expansion with a minimum of capital investment, The impact of the marginal loss in convenience to the boating patrons must be taken into account, bowever. This concern is brought abouc by the fact that the boats will be tiea "stern to" with access limited to over the transom from the wain walkway. when finger piers are removed, a loading dock must be substitutad for the original finger piors.

Scenario 2 a (Figure S1-7) assumes that the marina operators will be able to negotiate the acquisition oi the anuting public owned 0.73 acre parcel to the west of the case stury 
marina. It is proposed that this area be allocated for the long term parking and winter storage. The inclusion of this area, along with the parking lot to the north, will permit an increase of 80 berths, bringing the total capacity to 225 boats.

The aditional capacity is accommodated in three ways. Pirst, the large western-most dock and finger pier structure is reconstructed with double 35 foot slips for larger boats. second, the finger piers are removed from the center floating dock structure, and finally, the floatimg slips are added to the perimeter of the eastern cove (C).

onshore facilities in this proposal include a 7,925 square foot service building and an 8,500 square foot indoor storage structure. The site is arranged to allow for either double access or circular vehicular floy through the site. The acquistion of the adjacent vacant property and the town owned launching ramp will permit the enlargement of the yard work area and, subsequently, the winter storage capacity of the marina.

General improvements to the marina include the pavina and landscaping of the yard area and the addition of high intensity outdoor lighting.

Scenario $2 b$ (Figure s1-8) is also based on the assumption that the neighboring parcel to the west is acquired by the marina. The expansion of the boat capacity, in this case, is accomodated solely through the construction of an 8,500 square foot rack storage structure containing 80 boats of 25 feet in length or less. In the eastern cove, the existing floating 
dock and finger pier structure is relocated (C) and a fork lift bulkhead constructed in its place (F). The slips at the perimeter of the cove are primarily intended for temporary tie ups by the rack storage patrons.

The remainder of the water structures are not modified or reconstructed except for the repair of selected structures as necessary. The shore structures, on the other hand, will be replaced by a service building, as described in scenario $2 a$. and an 8,500 square foot indoor storage structure (B).

scenario 3 (Figure $51-9$ ) is by far the most ambitious of all the alternatives. This proposal is seen as a plan for the redevelopment of the entire coastal area surrounding the case study marina including the adjacent marina to the west. It is our belief that the land and water space that is available for recreational boating in the salt pond area is severely limited in comparison to the demañ for its use. In light of this, it would seem frudent for the community to adopt an overall plan for the development and operation of this area, thereby avoiding unnecessary duplication of services and at the same time, optimizing the use of the land and water resources available.

In this proposal, the original capacity of 137 slips is increased to 310 with the additional 163 boats accomodated hy a combination of slips (H) and a 100 boat rack storage structure (B). The shore facilities include a 10,000 square foot indoor storage structure (B) and a 13,000 square foot bi-level service structure. Furthermore, it is our objective with this proposal to consolidate and expand the retail 
services and the noncommercial functions of the marina. In this proposal a grocery store, laundry, electronics service center, gift shop and yacht brokerage are provided (D). In addition, this plan has considered the needs of a yacht sales function by providing 2,000 square feet for the indoor display of moderately sized boats (A).

It is our belief that the combination of the increased marina activity brought about by the enlargement of its capacity and the magnetic effects of agglommating diverse comercial activities, will generate sufficient demand for the marina to make its retail functions feasible.

It should be pointed out that this proposal is conditioned on the inclusion of all nearby parking areas that are presently designated for public use. 
DEVELOPMENT ALTERNATIVES

ALLOCATION OF LAND \& WATER SPACE

STONE COVE MARINA

\begin{tabular}{|c|c|c|c|c|c|c|}
\hline & Existing & $\begin{array}{l}\text { Scenarto } \\
1 \mathrm{a}\end{array}$ & $\begin{array}{l}\text { Scenario } \\
1 b\end{array}$ & $\begin{array}{l}\text { Scenario } \\
2 a\end{array}$ & $\begin{array}{l}\text { Scenario } \\
2 \mathrm{~b}\end{array}$ & $\begin{array}{l}\text { Scenario } \\
3\end{array}$ \\
\hline $\begin{array}{l}\text { Total land area } \\
\text { under marina control }\end{array}$ & 3.06 & 3.93 & 3.93 & 4.66 & 4.66 & 6.00 \\
\hline Private Parking & .58 & 1.24 & 1.24 & 1.40 & 1.40 & 2.04 \\
\hline Yard Nork Area & 2.18 & 2.29 & 2.29 & 2.76 & 2.66 & 3.00 \\
\hline $\begin{array}{l}\text { Buildings and } \\
\text { Unused area }\end{array}$ & .30 & .40 & .40 & .50 & .60 & .96 \\
\hline $\begin{array}{l}\text { Land not controlled } \\
\text { by marina }\end{array}$ & 2.74 & 1.88 & 1.88 & 1.15 & 1.15 & $-0-$ \\
\hline Public Parking & 1.37 & .51 & .51 & .51 & .51 & $-0-$ \\
\hline Vacant & .73 & .73 & .73 & $-0-$ & $-0-$ & $-0-$ \\
\hline Other & .64 & .64 & .64 & .64 & .64 & $-0-$ \\
\hline Water Area & 3.70 & 4.74 & 4.20 & 5.98 & 5.98 & 8.88 \\
\hline
\end{tabular}

Area in acres

Source: Bender \& Winsor 
DEVELOPMENT ALTERNATIVES

DISTRIBUTION OF BOATS \& SLIPS

BY SIZE

STONE COVE MARINA

\begin{tabular}{|c|c|c|c|c|c|c|c|}
\hline & $\%$ & Existing & $\begin{array}{l}\text { Scenario } \\
\text { la }\end{array}$ & $\begin{array}{l}\text { Scenario } \\
\text { lb }\end{array}$ & $\begin{array}{l}\text { Scenario } \\
2 \mathrm{a} \\
\end{array}$ & $\begin{array}{l}\text { Scenario } \\
2 \mathrm{~b}\end{array}$ & $\begin{array}{l}\text { Scenario } \\
3\end{array}$ \\
\hline $20^{\prime}$ & .49 & 52 & 81 & 88 & 114 & 108 & 166 \\
\hline $21^{\prime}-25^{\prime}$ & .19 & 47 & 41 & 42 & 43 & 67 & 88 \\
\hline $25^{\prime}-30^{\prime}$ & .20 & 25 & 30 & 41 & 45 & 40 & 50 \\
\hline $31^{\prime}-35^{\prime}$ & .04 & 7 & 6 & 6 & 6 & 6 & 16 \\
\hline $35^{\prime}$ & .08 & 6 & 12 & 12 & 14 & 15 & 12 \\
\hline TOTAL & 1.00 & 137 & 170 & 189 & 222 & 233 & 330 \\
\hline
\end{tabular}

Berthing Capacity

(slips)

\begin{tabular}{ccccccc}
\hline $20^{\prime}$ & 71 & 105 & 130 & 114 & 84 & 78 \\
$25^{\prime}$ & 14 & 14 & 21 & 24 & 19 & 78 \\
$28^{\prime}-30^{\prime}$ & 44 & 44 & 31 & 48 & 43 & 58 \\
$30^{\prime}$ & 8 & 7 & 7 & 36 & 7 & 16 \\
Rack Storage & -0 & $-0-$ & $-0-$ & $-0-$ & 80 & 100 \\
\hline TOTAL & 137 & 170 & 189 & 222 & 233 & 330
\end{tabular}


DEVELOPMENT ALTERNATIVES / SPATLAL ALt OCATION OF SHORE FACILITIES

STONE COVE MARINA

\begin{tabular}{|c|c|c|c|c|c|c|}
\hline TOTAL & EXISTING & $\begin{array}{l}\text { Scenario } \\
\mathrm{la}\end{array}$ & $\begin{array}{l}\text { Scenario } \\
1 \mathrm{~b}\end{array}$ & $\begin{array}{l}\text { Scenario } \\
2 \mathrm{a}\end{array}$ & $\begin{array}{l}\text { Scenario } \\
2 \mathrm{~b}\end{array}$ & $\begin{array}{l}\text { Scenario } \\
3 \\
\end{array}$ \\
\hline Shore Facilities, total & 4307 & 6520 & 6520 & 16425 & 24925 & 33075 \\
\hline Hull Repair & 600 & 2100 & 2100 & 2800 & 2800 & 2800 \\
\hline Engine Repair & 1500 & 1000 & 1000 & 1200 & 1200 & 1200 \\
\hline Parts \& Engine Sales & 1400 & 630 & 630 & 750 & 750 & 780 \\
\hline Accessories & 25 & 540 & 540 & 600 & 600 & 700 \\
\hline Gifts & $-0-$ & $-0-$ & $-0-$ & $-0-$ & $-0-$ & 600 \\
\hline \multicolumn{7}{|l|}{ Restrooms \& } \\
\hline Showers & 350 & 750 & 750 & 800 & 800 & 900 \\
\hline Gear Storage & 350 & 700 & 700 & 800 & 800 & $80 ?$ \\
\hline Utilities & $-0-$ & 100 & 100 & 125 & 125 & 230 \\
\hline Grocery & $-0-$ & $-0-$ & $-0-$ & $-0-$ & $-0-$ & 490 \\
\hline Laundry & $-0-$ & $-0-$ & $-0-$ & $-0-$ & $-0-$ & 375 \\
\hline E1ectronics & $-0-$ & $-0-$ & $-0-$ & $-0-$ & $-0-$ & 600 \\
\hline office & 75 & 200 & 200 & 250 & 250 & $40 ?$ \\
\hline Brokerage & $-0-$ & $-0-$ & $-0-$ & $-0-$ & $-0-$ & 300 \\
\hline New Boat Sales & $-0-$ & $-0-$ & $-0-$ & $-0-$ & $-0-$ & 2000 \\
\hline Snack Bar & $-0-$ & 500 & 500 & 600 & 600 & 900 \\
\hline Indoor Boat Storage & $-0-$ & $-0-$ & $-0-$ & 8500 & 8500 & 10000 \\
\hline Rack Storage Building & $-0-$ & $--0-$ & $-0-$ & $-0-$ & 8500 & 10000 \\
\hline TOTAL BOATS & 137 & 170 & 189 & 222 & 233 & 330 \\
\hline
\end{tabular}

area in square feet 
Figure S1-4

STONE COVE MARINA - EXISTING CONDITIONS

1. Slips area

2. Fue 1 dock

3. Hauling/ launching ramp area

4. Yard working area/ winter storage

5. Sales, administration

6. Service, outboard motor storage

7. Rest rooms, shower building

8. Outdoor equipment storage

9. Public launching ramp

10. Vacant waterfront land

11. Public parking

12. Marina parking

13. Adjacent marina

$\begin{array}{lr} & \text { Total } \\ \text { Slips } & 137 \\ \text { parking places } & 110\end{array}$

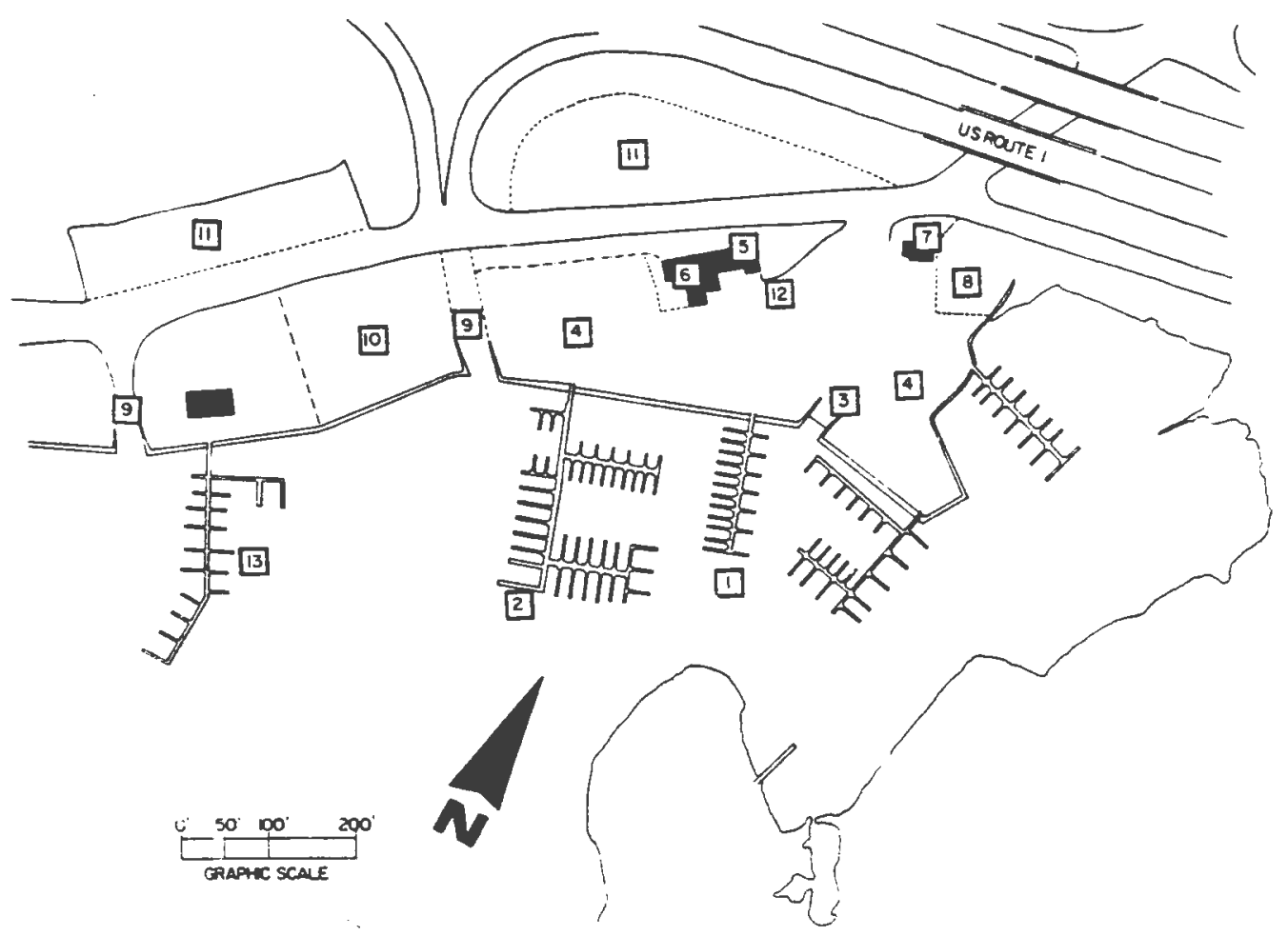

\section{MARINA STUDY acoeen unson 1979}


1. Slips area

2. Fuel dock

3. Hauling/ launching ramp

4. Yard working area/ winter storage

9. Public launching ramp

10. Vacant waterfront land

11. Public parking

12. Marina parking

13. Adjacent marina

\section{CHANGES}

A. Indoor hull service facility - two stories, $50^{\prime} \times 42^{\prime}$

B. Two level bullding with sales, administration and snack bar on second floor; service, parts departments and rest rooms, showers on the first floor

C. Indoor equipurent storage

D. Additional finger piers - 24 slips

E. Multi-use walkway - short term tie-up/fingerless stern-to mooring on one side, giving 10 slips each $8^{\prime}$ width

F. Relocation of inner pier to accomodate change

$\begin{array}{lcc} & \text { Added } & \text { Total } \\ \text { Slips } & 33 & 170 \\ \text { Parking places } & 45 & 155\end{array}$

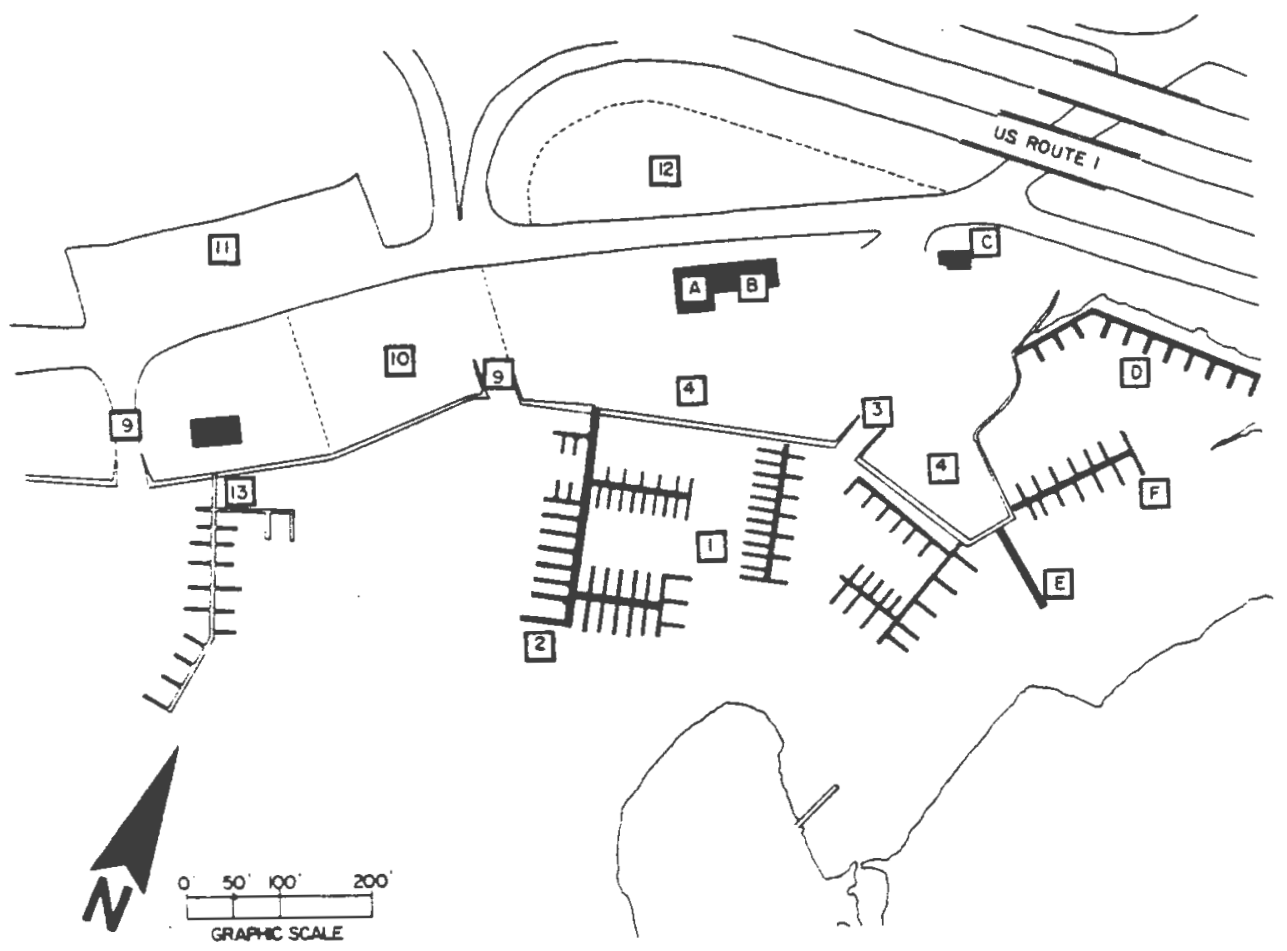

MARINA 
1. Slips area

2. Fuel dock

3. Hauling/ launching ramp

4. Yard working area/ winter storage

9. Public launching ramp

10. Vacant waterfiont land

11. Public parking

12. Marina parking

13. Adjacent marina

$\overline{\text { GHANGES }}$

A. Indoor hull service facility - two stories, $50^{\prime} \times 42^{\prime}$

B. Two level building with sales, administration and snack bar on second floor; service, parts departments and rest rooms, showers on the first floor

C. Indoor equipment storage

D. Removal of fingers from existing dock and add-on 32' (adds up to 22 boats)

E. Multi-use walkway - short term tie-up/fingerless stern-to mooring on one side, giving up to 10 additional slips

F. Remove fingers from two docks (adds up to 21 boats)

$\begin{array}{lcc} & \text { Added } & \text { Total } \\ \text { Slips } & 52 & 189 \\ \text { Parking places } & 45 & 155\end{array}$

(Removal of finger piers for majority of boats in the under $25^{\prime}$ class)

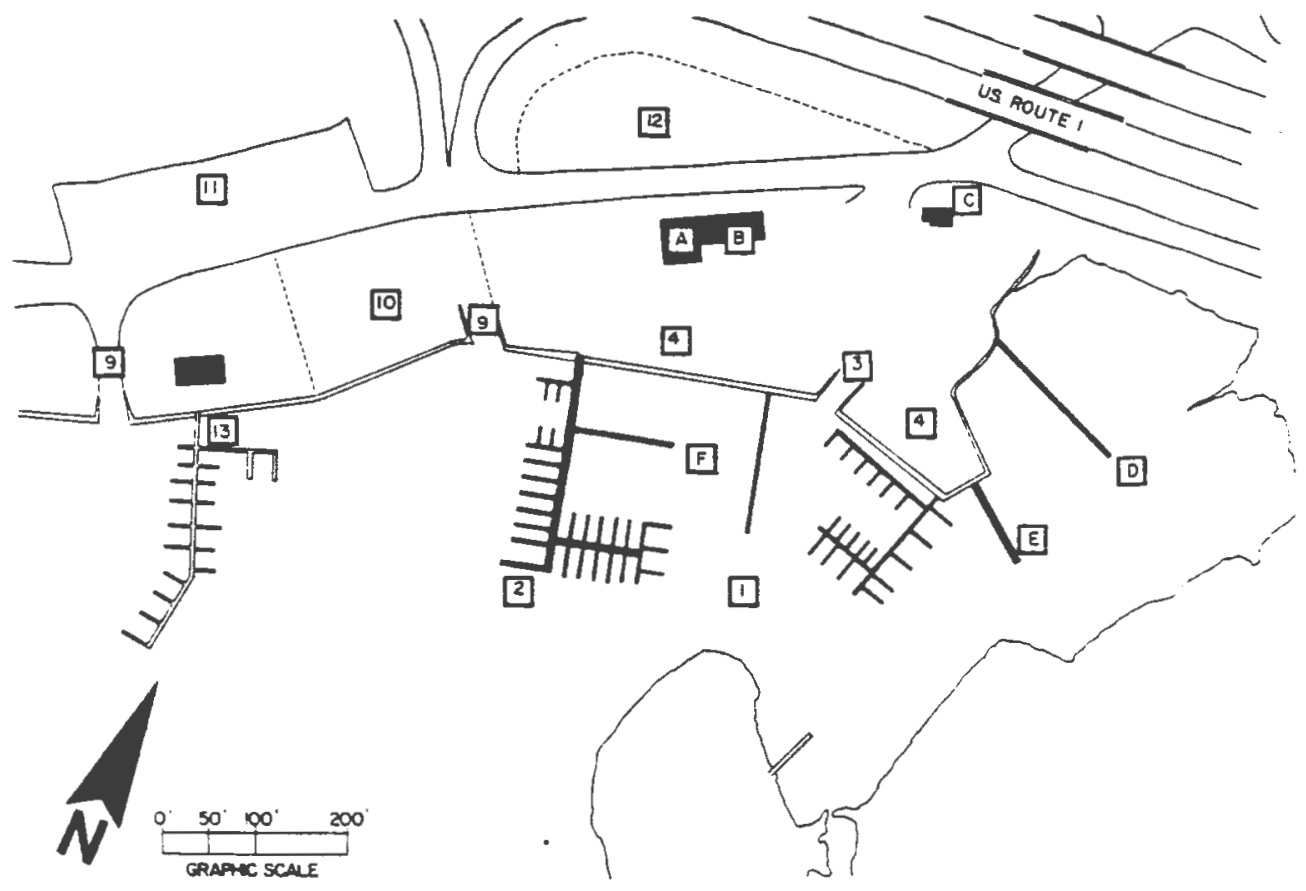

\section{MARINA STUDY


Figire $51-7$

STONE COVE MARINA - SCENARIO $2 A$

1. Slips area

2. Fuel dock

3. Hauling/launching ramp

4. Yard working area/winter storage

5. Administration

6. Service area

8. Outdoor equipment storage

9. Public launching

10. Marina short-term parking

11. Public parking

12. Marina long-term parking

13. Adjacent marina

\section{CHANGES}

A. Sales

B. Indoor storage, $85^{\prime} \times 100^{\prime}$

C. Additional finger slips

D. Snack bar, showers $\&$ rest rooms on lower level

F. Remove fingers from dock

$\begin{array}{lcc} & \text { Added } & \text { TOTAL } \\ \text { Slips } & 85 & 222 \\ \text { parking places } & 65 & 175\end{array}$

(Acquire adjacent property)
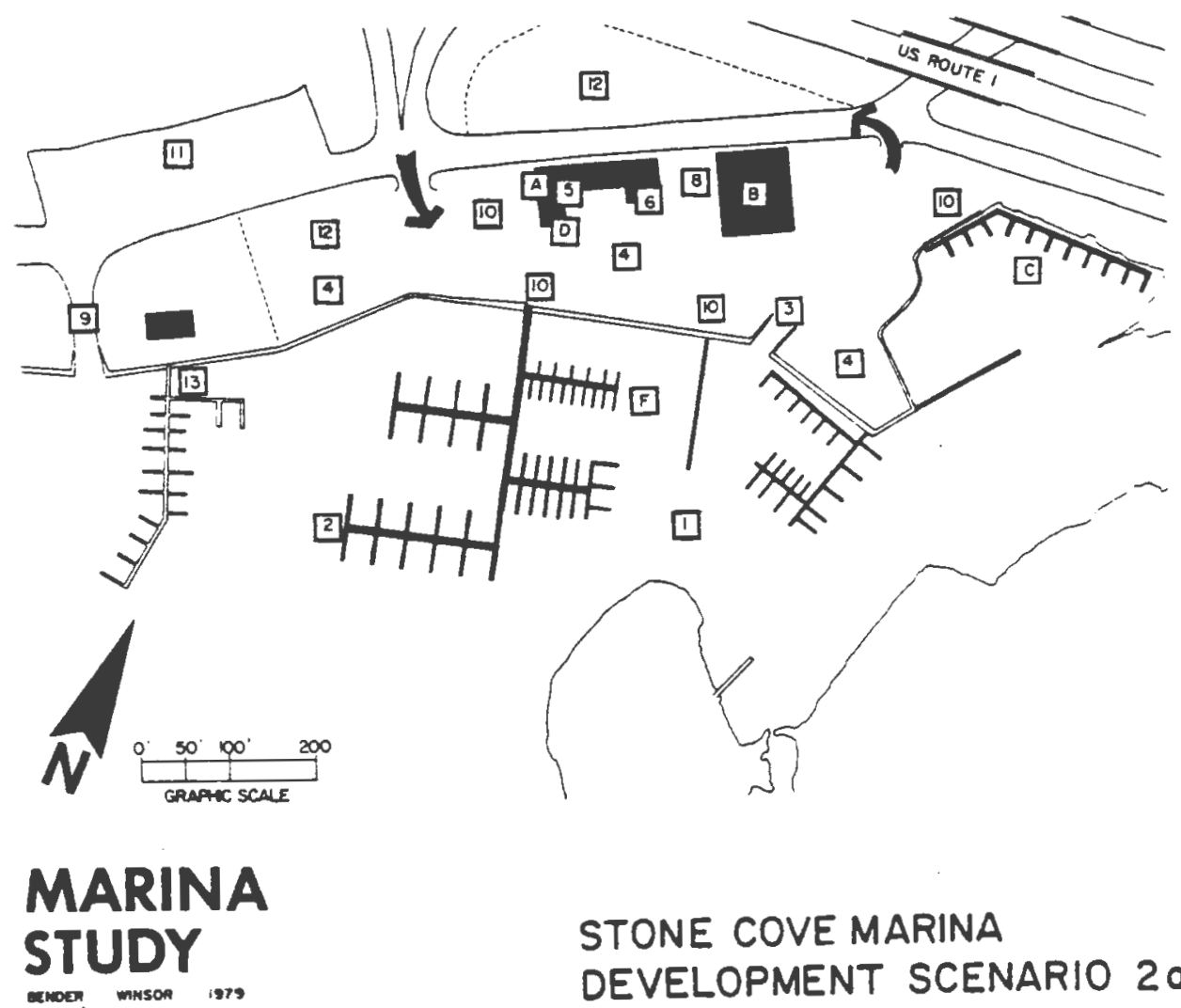
1. Slipe area

2. Fuel dock

3. Hauling/ launching ramp

4. Yard working area/ winter storage

5. Aduinistration

6. Service area

8. Outdoor equipment atorage

9. Public launching

10. Marina short-term parking

11. Public parking

12. Marina long-term parking

13. Adfacent marina

CHANGES

\section{A. Sales}

B. Indoor storage, $85^{\prime} \times 100^{\prime}$

C. Temporary slip area for rack storage

D. Snack bar, showers \& regt rooms on lower level

E. 80 boat rack-stack, 4 level rack storage, $85^{\prime} \times 100^{\prime}, 60^{\circ}$

F. Bulkhead for forklift

$\begin{array}{lcc} & \text { Added } & \text { Tota1 } \\ \text { Rack stacks } & 80 & 80 \\ \text { S1ips } & 16 & 153 \\ \text { Parking place } & 65 & 175\end{array}$

(Acquire adfacent property)

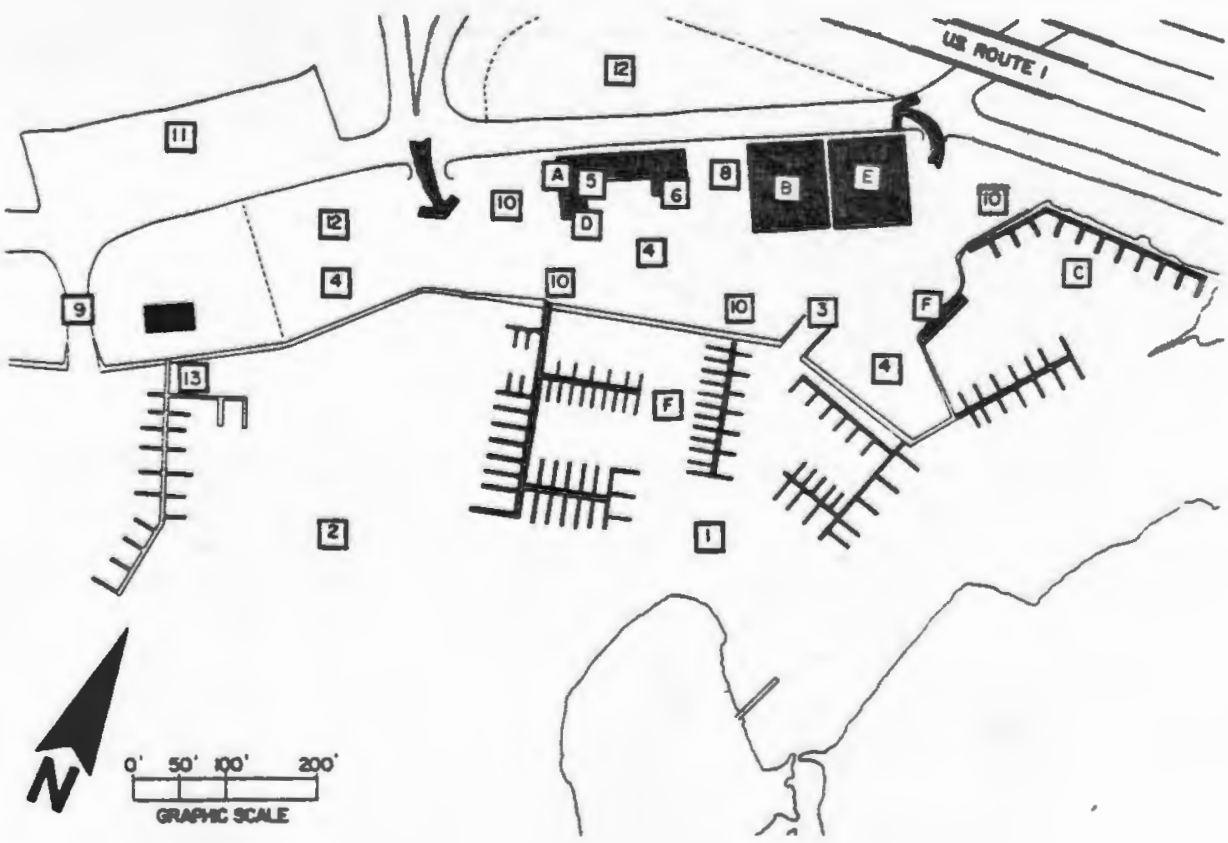

MARINA 
2. Fuel dock

3. Hauling/ launching ramp

5. Administration

6. Service Area

9. Public launching area

10. Marina short-term parking

12. Marina long-term parking

\section{CHANGES}

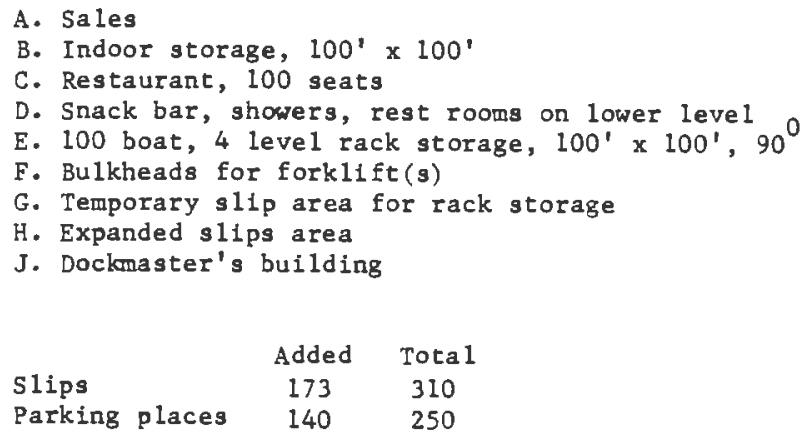

(Acquire adjacent marina)
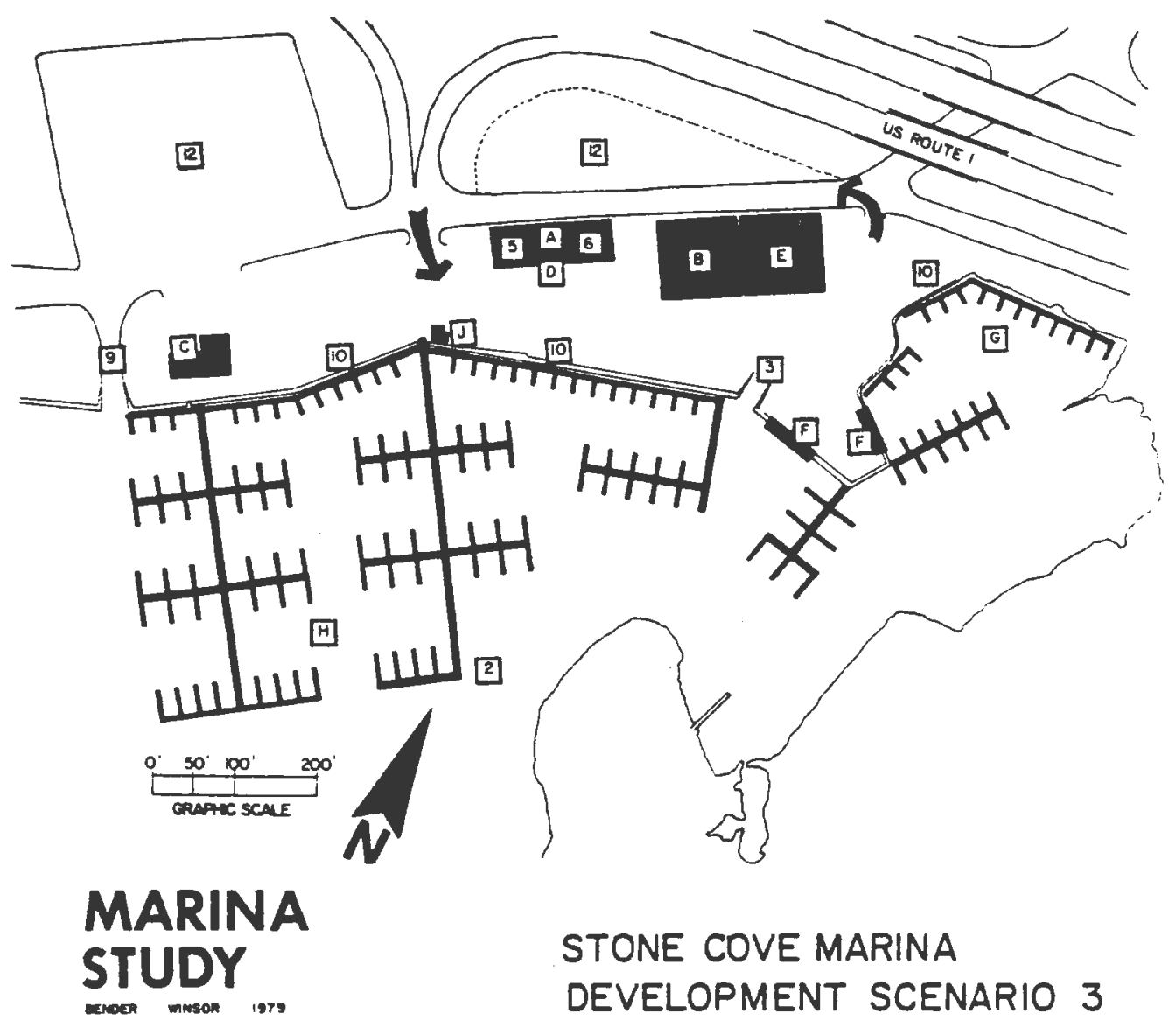
DESCEIPTION OF DEVFLOPMENT ALTERNATIVES

CATAUMET MARINA

The description of the development alternatives for the Stone Cove Marina described the critical relationship between the proposed number of boats, the allocation of land and water space and the spatial allocation of shore facilities. Figures s2-1. s2-2 and s2-3 document these relationships as apnlied in the development scenarios for Cataumet Marina.

As was illustrated in the case study profile of cataunet Marina, this facility has evolved into an impressive boating center. Nevertheless, there is some potential for iuprovement of its physical facilities and commercial diversity.

The objectives for the future develnpment of this marina are, first, to expand the marina's capacity and, second, to further diversify the complex into a recreational center.

The agglomeration effect of concentrating goods and services on a well organized physical site allows each service to benefit by its proxinity to the others. This is evidenced by the existing organization of facilities at the cataumet Marina in wich the seven acre site is occupied by no less than 32,000 square feet of service, retail and administrative space (figure s2-1). Under normal circumstances, the number of boating patrons which frequent the marina would be insufficient to justify the size of certain comercial functions, 
narticularly the restaurant and marine store. The conmercial attraction for these and other functions is largely supported by outside clientele that is crawn to the marira by the mixture of commercial enterprizes in this unique location.

In the following development scenarios, the commercial viability of the complex is considered to remain constant and the demand for its products is expected to be less a function of berthing capacity than external market demand.

It is the purpose of the first two scenarios, therefore, to optimize the present facilities as much as possible. maintaining the existing shore facilities intact and enlarging the boater population through slip expansion.

Scenario 1 (Figure $52-2$ ) involves little overall change in the marina, but addresses the most immediate need which is to replace the deteriorated outer docks and finger piers. An additional floating dock structure is proposed in this scenario with the total berthing capacity increased from its present 175 boats to 224 boats. When the number of vessels kept on moorings is added to this, the total capacity becomes 279 boats. since the land area under the control of the marina remains at slightly less than 10 acres, the plan must incorporate a number of structural changes to allow the vehicular parking capacity to be increasen to meet the new demand created by moro berths. An aditional 30 parking spaces are provide on the site by the relocation of a yooden storage shed and the removal of the Sandwich racht club from the premises (Iten 12).

The new outer dock system is to be protected by a scrap 
tire floating breakwater. This method of wave protection has performed reasonably well for Cataumat over the last several seasons and is therefore proposed for expanded use.

scenario 2 (Fiqure $52-3$ ) recognizes that the berthing capacity of Cataumet Marina is constrained by the land area that is avalable for vehicular parking. In order to make any significant increases in the boating population it is first necessary to expand the marina land parcel. This is

accomplished by the acquisition of an adjacent 1.0 acre parcel for which the marina owner holds a purchase option. The acquired land would then be linked with an existing 3.9 acre parcel wich the marina controls. Unfortunately, these two properties are not physically connected, which necessitates some major site modifications. As shown in Fiqure s2-1, the small Red Brook inlet separates the the two parcels. In Figure s2-3, the parcels are joined by a combination of cuts and fills with the water course rerouted through a culvert. The filled area now allows for a continuous road system around the perimeter of the inner yacht basin which leads to the public road at the town launch ramp (Items 9 and 11). To manipulate the brook in this manner may not be acceptable to the community, hovever, so an alternative bridge structure could be considered as a substitute for the excavation solution.

Whether by use of a bridge structure or earth work, the expanded parcel will accommodate the increased parking that is necessary for additional slips. The new dock structures that are shown can berth approximately 43 boats, most of which would be larger than 25 feet in length. Including the existing 
moorings, the total capacity of the marina is raised to 322 boats.

Scenario 3 (Figure s2-4) takes a much different look at the problem of marina expansion. First of all, this alternative attempts to break out of the bonds that are imposed on the planning effort by ownership patterns. It is our opinion that the geography of the vicinity around Catamet Marina is such that it would be better served by a comprebensive approach to the development of the waterfont area.

At present, Cataumet Marina coexists with the Red Brook Boatyard. The fact that they have apparently survived together indicates that they are serving different clients. Red Brook, for example, cators to the yachtsman who pefers to keep his boat on a mooring wile cataumet, with with many more slips than moorings, definitely appeals to those boaters who prefer to berth their boats.

The contrasting service and use characteristics of these two marinas can work to their advantage if both facilities are organized to complement one another. As can be seen in Figure 52-4, the direction of growth of the cataumet facility is in the direction of the red Brook Boatyard. As more shore line slips are added, the distance from the berths to the central service complex increases to the point where it is no lonqer convenient for patrons to use those services. By inclusion of the Bed Brook yard into the cataumet complex it would be possible to organize the service activities of both so that ped Brook would function as a satellite service center. Furthermore, this center could continue to operate as a shore 
support complex for the local yachtsmen who keep their boats on moorings.

It would seem that the aggregation of these activities into a single organizational unit would allow for a more efficient use of both marina properties as well as avoid duplication of services.

To describe the specifics of this plan, the existing mooring area, shown in figure $52-4$ as the shaded area, is retained, however, 15 to 20 of the existing 165 moorings will be sacrificed to permit the use of the floating breakwater system and the expanded berths. Special facilities for the moored boats, includina a launch service, short term loading dock, parking and indoor dinghy storage are provided at the satellite service facility. The existing house, which is identified as letter $G$ in figure 4 is proposed for conversion into an "old New England style inn", providing accommodations and dining for marina patrons and the public at large.

To complete the plan, a swimming pool has been constructed on the small hill top adjacent to the railway providing a panoramic view of the marina activity below.

All of the alternatives which have been discussed are based on the assumption that the size distribution of boats will approximate the prevailing ratio and that each proposal specifies an optimum mixture of slip sizes to accommodate the assumed distribution of boats. The pattern of boat size is tempered, however, by the marina ownor's long range objective to attract a larger more profitable fleet. To satisfy both the empirical data which establishes the proportional breakdown of 
the fleet by length and the owner's objectives, the combination of slip length is proposed as a flexible condition in which boat length can vary without significant problems or excessive cost to the operator (Figure $52-2$ ).

The facilities' spatial requirements for the three scenarios are explained in some depth in Figure s2-3. As was mentioned earlier, the space wich is presently avalable for all functions except parking is believed to be adequate. For this reason, the bulk of the shore facilities remin unchanged. 
DEVELOPMENT ALTERNATIVES

ALLOCATION OF IAND \& WATER SPACE

CATAUMET MARINA

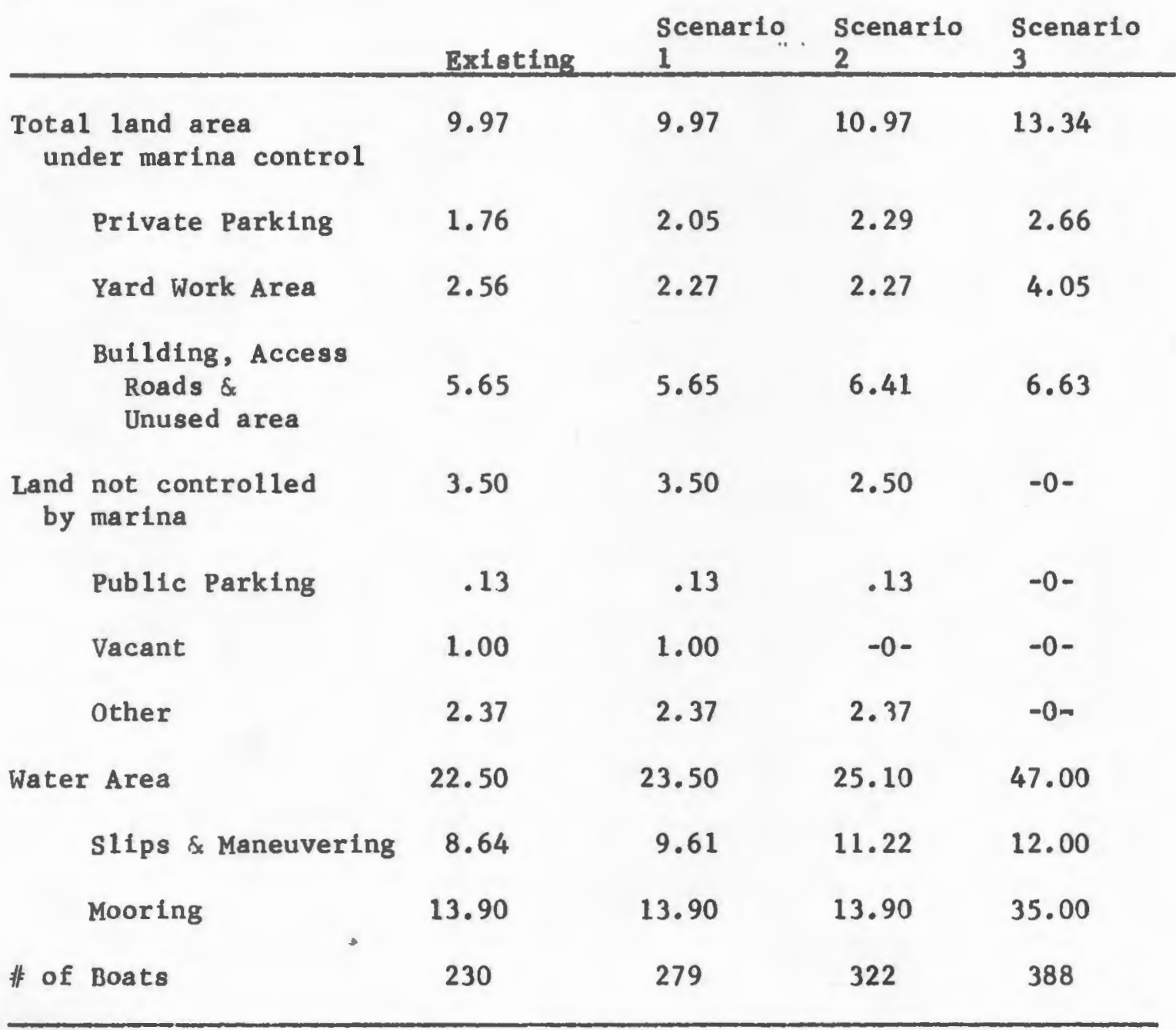

* Area measured in Acres 
DEVELOPMENT ALTERNATIVES

DISTRIBUTION OF BOATS \& SLIPS

BY SIZE

CATAUMET MARINA

\begin{tabular}{|c|c|c|c|c|c|}
\hline Boat Length & $\%$ & Existing & $\begin{array}{l}\text { Scenario } \\
1\end{array}$ & $\begin{array}{l}\text { Scenario } \\
2\end{array}$ & $\begin{array}{l}\text { Scenario } \\
3\end{array}$ \\
\hline$<20^{\prime}$ & .09 & 18 & 25 & 29 & 35 \\
\hline $21^{\prime}-25^{\prime}$ & .23 & 47 & 64 & 74 & 89 \\
\hline $26^{\prime}-30^{\prime}$ & .30 & 58 & 84 & 97 & 116 \\
\hline $31^{\prime}-36^{\prime}$ & .16 & 31 & 45 & 51 & 63 \\
\hline$>36^{\prime}$ & .22 & 41 & 61 & 71 & 85 \\
\hline TOTAL & 1.00 & 195 & 279 & 322 & 388 \\
\hline
\end{tabular}

Berthing Capacity

by Length (slips)

\begin{tabular}{lrrrr}
$20^{\prime}$ & 39 & 39 & 39 & 39 \\
$25^{\prime}$ & 24 & 24 & 38 & 44 \\
$28^{\prime}-30^{\prime}$ & 37 & 46 & 58 & 58 \\
$730^{\prime}$ & 80 & 115 & 132 & 132 \\
Rack Storage/Moorings & $0 / 55$ & $0 / 55$ & $0 / 55$ & $0 / 115$ \\
\hline TOTAL & 235 & 279 & 322 & 388
\end{tabular}

Source: Bender \& Winsor 
DEVELOPMENT ALTERNATIVES / SPATIAL ALLOCATION OF SHORE FACILITIES CATAUMET MARINA

\begin{tabular}{|c|c|c|c|c|}
\hline & EXISTING & $\begin{array}{l}\text { Scenario } \\
1\end{array}$ & $\begin{array}{l}\text { Scenario } \\
2\end{array}$ & $\begin{array}{l}\text { Scenario } \\
3\end{array}$ \\
\hline Total Shore Facilities & 32775 & 32775 & 32775 & 47975 \\
\hline $\begin{array}{l}\text { Hul1 Repair } . \\
\text { Engine Repair }\end{array}$ & $1900+$ & 1900 & 1900 & 5900 \\
\hline $\begin{array}{l}\text { Parts \& } \\
\text { Accessories }\end{array}$ & 1000 & 1000 & 1000 & 1000 \\
\hline Gifts & 600 & 600 & 600 & 600 \\
\hline $\begin{array}{l}\text { Restrooms \& } \\
\text { Showers }\end{array}$ & 1100 & 1100 & 1100 & 1350 \\
\hline Gear Storage & 600 & 600 & 600 & 900 \\
\hline Utilities & NA & NA & $\mathrm{NA}$ & $\mathrm{NA}$ \\
\hline Grocery & 375 & 375 & 375 & 375 \\
\hline Laundry & 500 & 500 & 500 & 500 \\
\hline Electronics & NA & NA & $\mathrm{NA}$ & NA \\
\hline offices & 1000 & 1000 & 1000 & 1100 \\
\hline Brokerage & 600 & 600 & 600 & 600 \\
\hline New Boat Sales & $-0-$ & $-0-$ & $-0-$ & $-0-$ \\
\hline Snack Bar & $-0-$ & $-0-$ & $-0-$ & $-0-$ \\
\hline Indoor Boat Storage & 19300 & 19300 & 19300 & 25850 \\
\hline Rack Storage Building & $-0-$ & $-0-$ & $-0-$ & $-0-$ \\
\hline Restaurant & 5800 & 5800 & 5800 & 5800 \\
\hline Lodging & $-0-$ & $-0-$ & $-0-$ & 4000 \\
\hline TOTAL BOATS & 230 & 279 & 322 & 388 \\
\hline
\end{tabular}


1. Slips area: 1A - Inner yacht basin

2. Fuel dock

3. Lift well

4. Yard Working area/winter storage

5. Sales, administration

6. Service, indoor storage

7. Restrooms, showers

8. Outdoor equipment storage

9. Public launching ramp

10. Marina owned property for expansion

11. Public parking

12. Marina parking

13. Restaurant

14. Yacht club, atorage shed

15. Dockmater's ahed

$\begin{array}{lc} & \text { Total } \\ \text { Moorings } & 55 \\ \text { S11ps } & 180 \\ * \text { Parking spaces } & 220\end{array}$

* Allocation of parking

a. Slips mooringe 158 spacea

b. Restaurant 62 spaces

Total $\overline{220}$ spaces

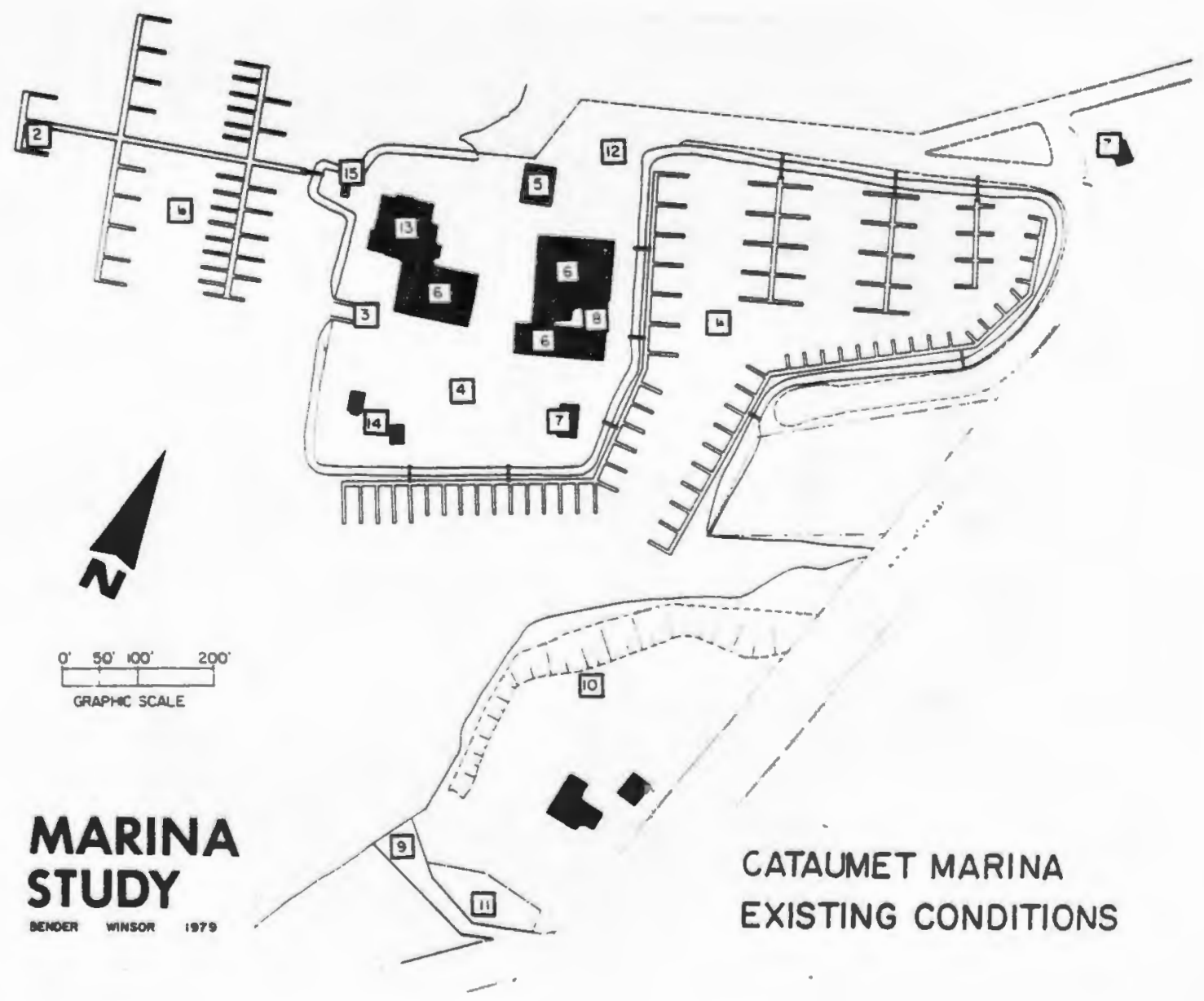


1. Slipe area: LA - Inner yacht bagin

2. Fuel dock

IB - outer floets

3. Lift vell

4. Yard working area/ winter storage

5. Sales, administration

6. Service, Indoor storage

7. Restrooms, showerg

9. Public launching ramp

10. Potential expansion ares

11. Public parking

12. Marina parking

13. Restaurant

15. Dockmester's shed

\section{GHANGES}

A. Floating breakater

B. Mooring area

C. Dinghy atacie

D. Now dock/elips

E. Reloceted torage shed

Parking area increased by $1 / 3$ acre to allow for 36 additional

cars. 48 sllps added.

$\begin{array}{lcc} & \text { Added } & \text { Total } \\ \text { Moorings } & 0^{\circ} & 55 \\ \text { Sllps } & 49^{\circ} & 224 \\ \text { Parking spaces } & 37 & 257\end{array}$

* Calculation of parking requirements

a. Demand slipa $\&$ mooring

(a. 7 spaces/boat

b. Restaurant

195 space:

$\frac{62}{\text { spaces }}$

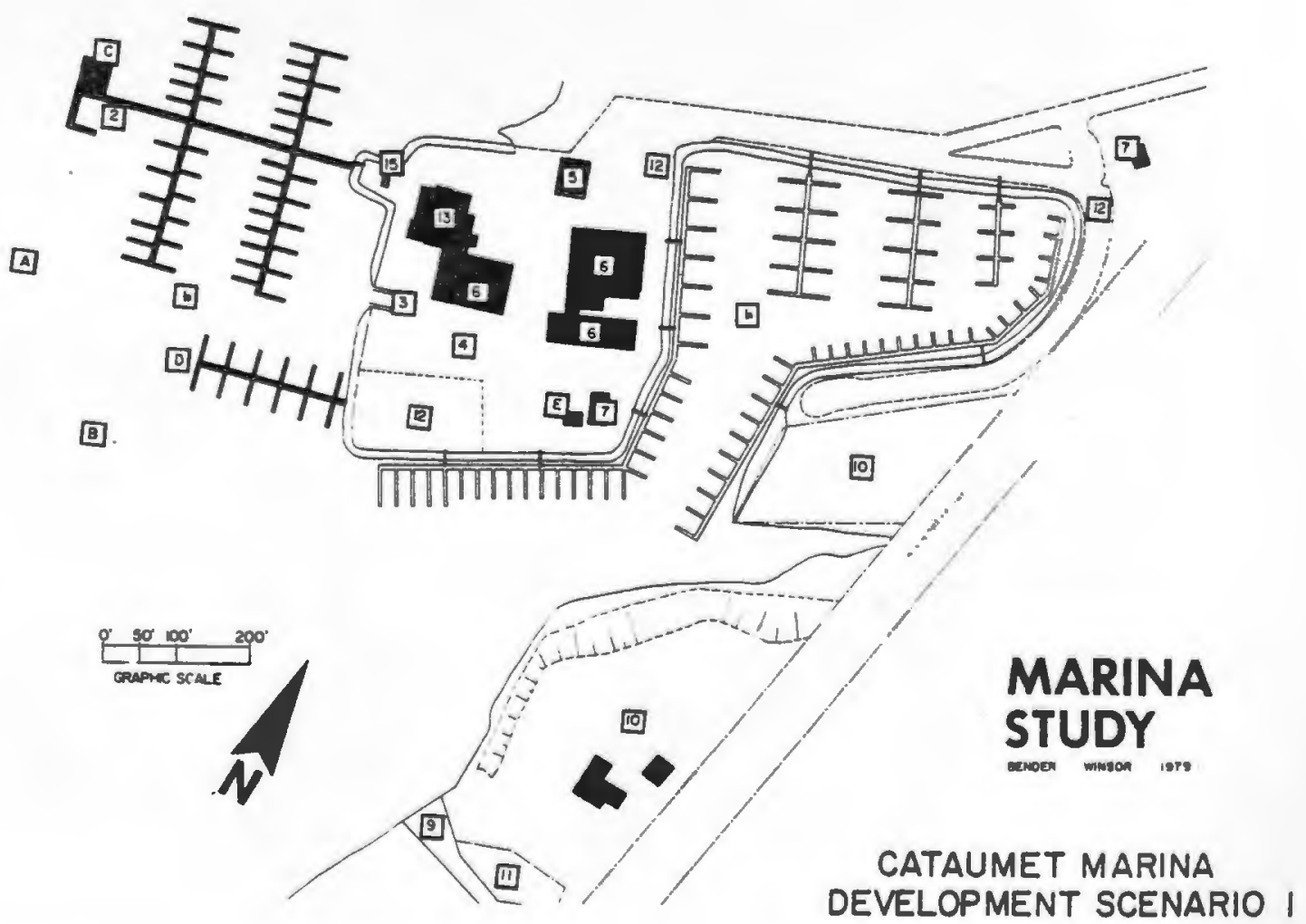


1. S11pe area: LA - Inner yacht basin

2. Fuel dock

IB - outer flont:

4. Yard worktag area/ winter storage

5. Sales, administration

6. Service, Indoor atorage

7. Rest rooms, showers

9. Public launching raup

11. Public parking

12. Marina parking

13. Restaurant

15. Dockmaster's shed

\section{CHANGES}

A. Floating breaksater

B. Mooring area

C. Dinghy stacks

D. New dock/sl1pa

Z. Relocated storage shed

F. Satelite service faclilty

G. Lodglng

$\begin{array}{lcc} & \text { Added } & \text { Total } \\ \text { Moorlings } & -15 & 115 \\ \text { S11pa } & 92 & 273 \\ \text { * Parking spaces } & 92 & 388\end{array}$

(Adfolning marlas and adjacent vacant property are aquired, land orned for expanalon, and filled In Inlet are all proposed to be put into use.)

* Calculation of parking requirements

a. Demand, lipa 5 moorings

c. .7 apecea/boat

250 spaces
$\frac{62}{\text { spaces }}$
$\frac{312}{\text { spaces }}$

b. Restaurant

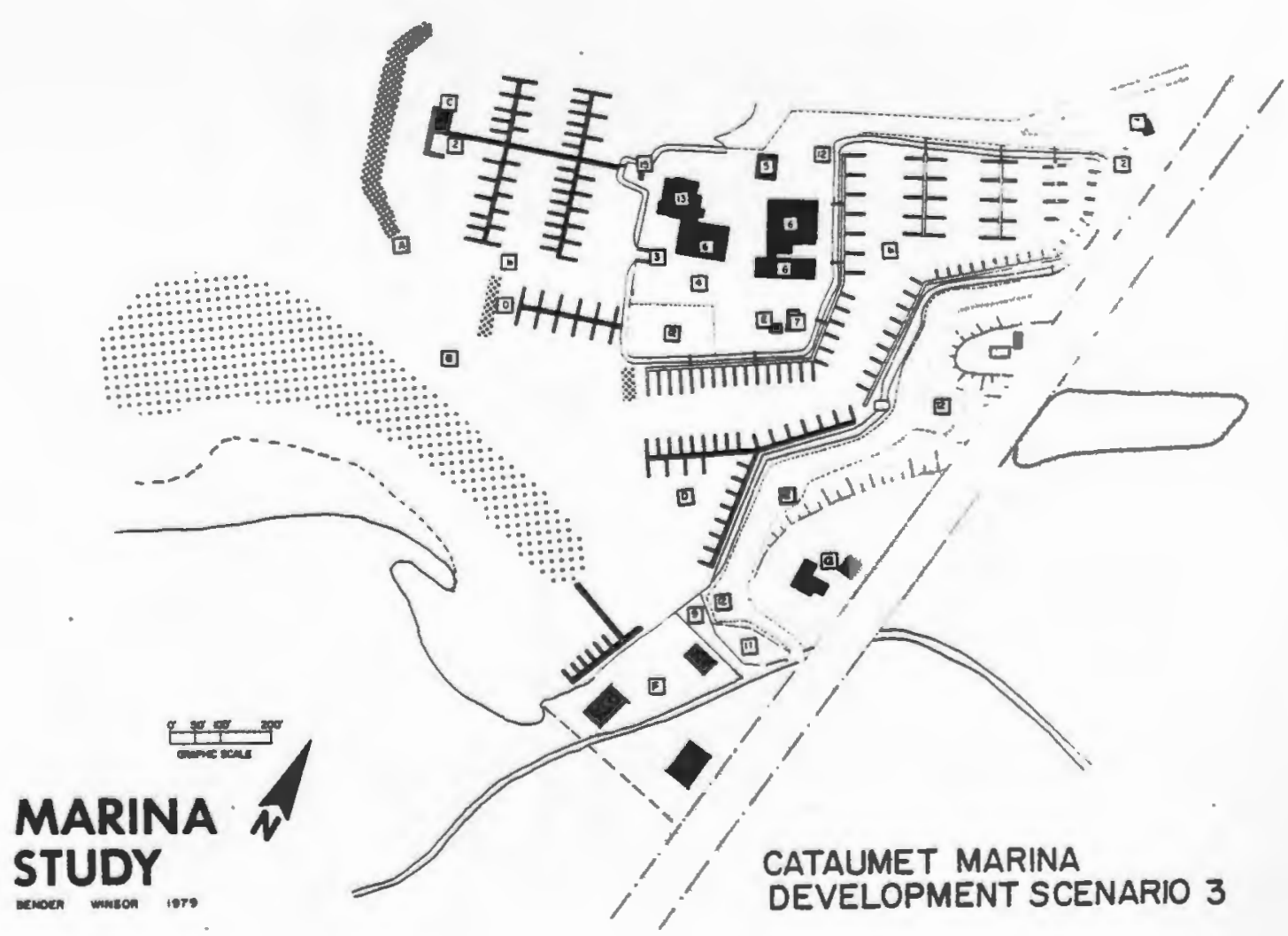


1. SIlps area: 1A - Inner yacht basin

2. Fuel dock

3. Lift well

4. Yard working area/ winter storage

5. Sales, adminlstration

6. Service, Indoor storage

7. Restrooms, showers

9. Public launching ramp

11. Public parking

12. Marina parking

13. Restaurant

15. Doclomater's shed

\section{CHANGES}
A. Floeting breakuater
B. Mooring area
C. Dinghy track
D. Now dock/alips
E. Relocated storage shed

Acquistion of adjacent vacant property and filling in of small Inlet ( 1.1 acres) as wall as land owned for expantion are proposed for use a follows: Addistional parking for 100 cars and 132 added sips (above and beyond those added in Scenario 1)

$\begin{array}{lrc} & \text { Added } & \text { Total } \\ \text { Moorlags } & \theta & 55 \\ \text { Sllps } & 87 & 267 \\ \text { * Parking spaces } & 136 & 356\end{array}$

* Colculation of parking requirementa

a. Demand slips of moorings

Q .7 spaces/bost 225 spaces

b. Restaurant 62 spaces Total $\overline{287}$ spacea

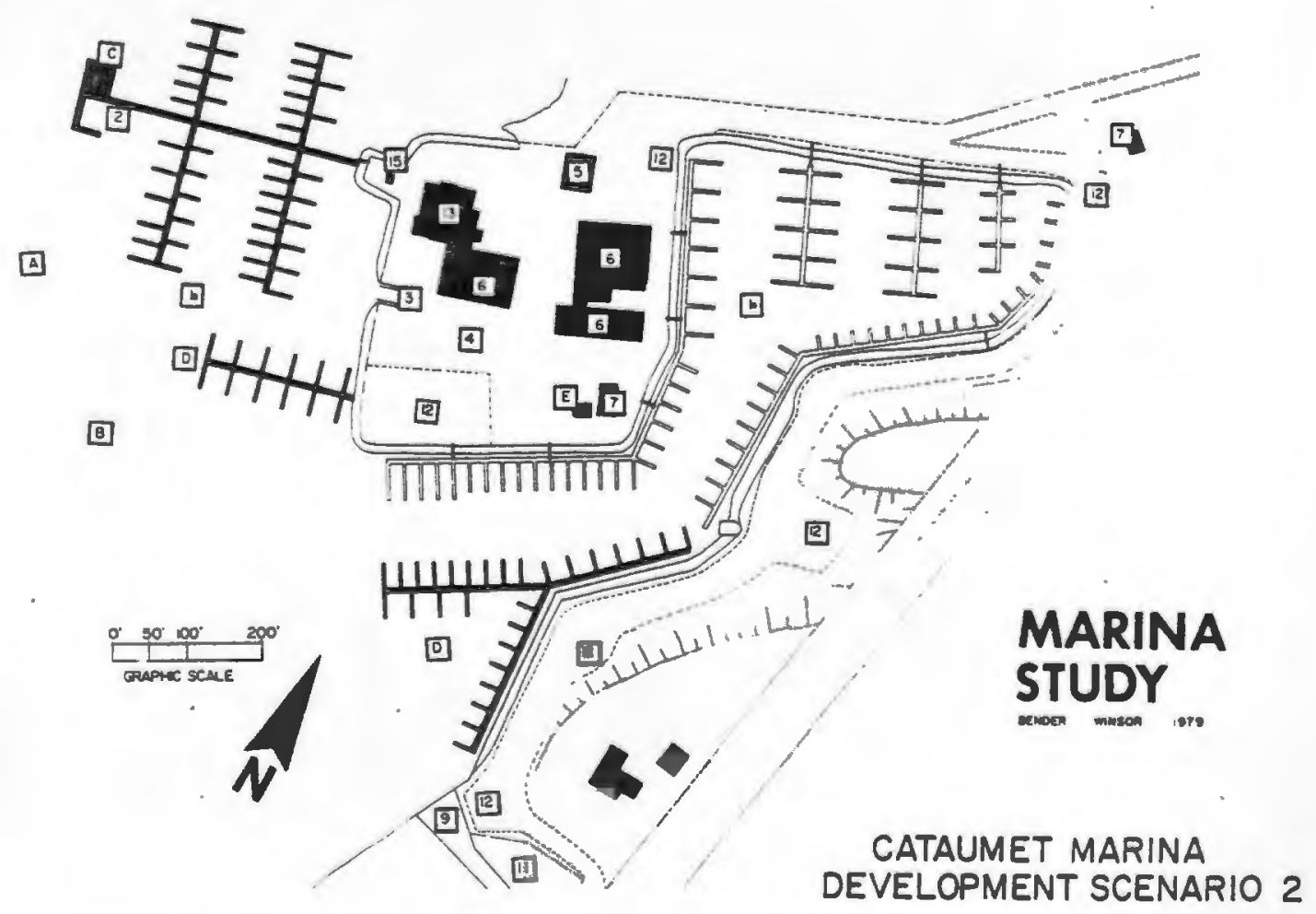


COMPARATIVE EVAIUATION OF DEVEIORMENT ALTBRATIVES

\section{BACK GROUND}

The final step in the planning process is the identificaricn of those development alternatives which, according to certain criteria, are the most successful in accomplishing the develcpwent goals within given parameters of cost and impact.

This section, therefore, is a review of the proposals and is intended to establish the feasibility of the individual proposals from the perspective of their econonic, functional and spatial viabilitp. The method emplcyed is a comparison of one alternative to ancther with particular emphasis on four main features: cost, service, sface and environmental conflict.

The element of cost or the financial comatment which is required for the implementation of the alternative is charactorized as a function of cost ratios, e.g.. the value of marine structures to the total cost of the development, and unit values, e. 9 . , the cost of each additional berth.

service, as an indicator of the success of the alternative, is quantified by the level of service achieved by each alternative and the unit cost involved in developing that additional service. This factor is considered to be most useful in evaluating the cafacity of the marina as a "full service facility".

Another majer area cf comparison is space, or the quantity 
of land and water that are consumed in the development process by each alternative. For this pcrtion of the study, the spatial characteristics of the proposals are examined from the point of view of the proportional allocations of land and water that is encompassed by the marina cperation.

The final area cf compariscn is the level of environmental conflict wich is precipitated by the alternative. Those proposals which specify major changes which require sanction by various permitting aqencies bave an inherent disadvantage when one considers the time and expense involved in the permit process. Those proposals wich effectively aroid major environmental issues, and, at the same time, accomplish the development goals, are of greater importance to the warina planner.

COST COMPARISCN OF LEVELOPMENT ALTERNATIVES

BUDGETARY ESTIHATES

One the most effective ways of evaluating the worth of capital investments is tc compare the estimated cost of development with the performance of the final froduct, which in the case of marina planning, is the number of boats and the extent of shore facilities which can be developed. To this end, cost estimates have been prepared for the develcpment scenarios for both marina sites. 
Before going into a discussion of the relative value of each proposal, it is believed that a general explanation of the estimating procedure is in crder. First, it should be made very clear that accurate cost estimates are only possible when the the sccpe of the proposed development is definitely known and certain engineering details specified. obviously, a study such as this, which attempts only to ascertain fundamental feasibility cannot be expected to supfly engineering solutions in sufficient detail to enable accurate cost estimation. It is possible, however, to approximate the relative value of the prorosals by develcping brcad unit costs wich can be applied to the physical characteristic of each alternative.

second, no value bas been estimated for the cost of land which ay have to te acquired to inplement certain scenarios. The capitalization of land acguisition would figure prominently in anv dotailed financial analysis of marina development, but, for the sake of simflicity and uniformity, it has been omitted from this comparison of the alternatives.

For the purposes of this study, the estimating process disaqqreqates the total estimated cost into three categories. The first, site work, includes the application of rip rap. excavation, fill, dredging, paving and landscaping. second is marine structures, including floating docks, piles floating breakwaters and mooring devices. Third is shore structures for service, storage, retail, office, heads, showers and swiming pools. The subcategcries as listed above represent the qreatest detail that is believed to be necessary in the preparaticn of such preliminary estimates. 
As can be seen in figures $c-1$ through $c-8$, individual unit costs have been devloped for each subcategory of each alternative. Since these units can be directly measured from the scenario plans it is fossible to arrive at reasonably accurate cost estimates for each item.

In most instances, the unit costs were derived from known standards such as the prevailing construction costs for various building and use types. Generally speaking, these estimates are very approximate and should be interpreted with discretion. The estimates are valuable, however, in making comparisons of the various proposals in that the unit costs were held constant from one alternative to the next. When the grouped estimates are correlated aqainst each other and the size of arina facilities, the dramatic ircrease in cost versus the achieved capacity is readily apparent.

Looking at the total estimated costs for the stone cove development alternatives the cost ranges from a 10 of $\$ 221,800$ for alternative 1 B to $\$ 844.567$ for alternative 3. The largest component of these estimates is the amount generated by shore structures. In most instances the shore facilities account for over $70 \%$ of the estimated value of the alternative. This relationsip is only surpassed by scenario 3 which proposes the complete reconstruction of all warine structures, hence the disproportionate share of the total amount. less than 56\% . which is devoted to shore structures.

Tho unit costs used in tho shore facilities estimates allow for the variation which can occur from one type of structure to another. For example, there are 5 type of structures for which 
unit costs have been develcfed, service, storage, retail, office, heads and showers. The unit costs for these items have been determined to fluctuate from $\$ 8.00$ per square foot for simple storaqe structures to $\$ 42.00$ per square foot for the more complicated facilities, such as those for toilets and showers.

After shore structures, the most expensive category of cost is marine structures. The nost costly alternative in this reqard is scenario 3 which proposes the complete reconstruction of the marine structures at stone cove.

\section{COST PER SLIP}

The most ccmmon indicator of facility cost is the unit measure of cost per slip. There is no question that this is a simplistic method of evaluation, but it does permit a relatively quick comparison cf various design alternatives. Furthermore, it can point out thcse alternatives with excessive values for additicnal berths. The method simply divides the estimated value of marine structures by the number of slips added by the alternative. As can be seen in figure $c-9$, the quotient varies considerahly. The smallest amount allocated for marine structures on a per slip basis is in stone cove scenario 2 B. This is explained by the fact that the increased capacity of the facility is largely the result of the rack storaqe structure the ccst of which is included in the shore structures category. The greatest per slip cost at stone cove is represented by scenario 3 where the unit cost is $\$ 1825$. 
This illustrates the relative value of marine structures on a per slip basis wen docks and flcating piers are completely reconstructed.

similar unit costs for Cataumet are noticably higher as the berths invclved are qenerally larger in size. The largest unit cost occurs in scenario 1, where the outer docks are reconstructed. Comparing the average per slip cost of both sites, it can be seen that the distribution of boat size at the two marinas has made a significant impact on the relative cost of developaent. COST RATIOS

The second method of comparing development costs is through cost ratios for the najor categories of development. As mentioned earlier, the three main cost categories are site work, marine structures and shore structures. Figure c-9 summarizes the total costs for these categories for each alternative as well as tabulates the ratio of individual component costs to the froject total. In the case of stone Cove, the estimated value of shore structures dominates the total cost, accounting for cyer $70 \%$ of the total except in scenario 3 where the total reconstruction of the dock systems altered the ratio. At cataumet marina, where the shore facilities are considered to be adequate, the marine structure componont is the most costly element in the development schemes.

It could be concluded from this analysis that rarina expansion projects in which the shore facilities are to be completely replaced, place a heavy financial emphasis on the 
construction of shore facilities with close to $70 \%$ of the total profect cost being asscciated with that category.

EVALUATION OF MARINA SERVICES

From the outset of the creation of development proposals for stone Cove and Cataumet Marinas, the principal objective was to expand the level of warina service to the point where the marina could be described as a "full service facility". This objective was somerbat acaderic at the cataumet site since the prevailing level of service exceeded that of most, if not a11. of its competition. At stone cove, however, the existing available services are considered to be in substantial need of expansion. Of the 15 basic services shown in figure $\mathrm{C}-1$, stone Cove presently maintains only 6. As indicated in figure c-10, the development alternatives incrementally increase the number of services offered until scenario three, where the level of service is equivalent to that at Cataumet Marina. The adition of these functions is not without cost, however. At the bottom of figure c-10, it can be seen that the net cost for the development of shore structures increases as more service options are offered. This simple analysis implys that the marina operators and developers, when ccnfronted with the prospct of steadily increasing cost may determino that there is a point of diminishing returns, were additional services cost more than the corresponding value cf the potential revenue that thep may qenerate.

A similar analysis of the cataumet site is not particularly 
useful, as this marina presently has a full complement of user services. The only services that are added to the complex are the lodging and swimuing pool, which are included in scenario three. The principal lcqic behind the cataumet scenarios is for the creation of greater berthing capacity which would increase the demand for the existing services. Investment in shore structures at this site is, therefore, negligible.

SPATIAL ANALYSIS

Another important factor in the assessment of the development alternatives is a analysis of the way in which the proposals optimize the available land and water area. The first level of comparison is the ratio of land to water. Most marina planning literature suggests that this will comonly be a 1:1 relationsip. Given the scarcity of waterfront real estate, however, it is cur opinion that marina planners should attempt to find ways to reduce the land element of this ratio.

In fiqure C-11, the space ratios are documented for each alternative. At stone cove, it can can be seen that the scenarios successively reduce the ratio from scenario 1 A to scenario 3. In cataumet, on the other hand, the ratio remains fairly constant. It is believed that the site configuration problems and difficult terrain at this location make it verg difficult to significantly improve the land to water ratio. 
Tho last major factor cf comparison is the relative level of environmental conflict that is caused by the execution of the development alternatives. For example, a proposal that requires a significant amcunt of dredging along with the construction of new dock systems, will have greater environmental conflict than a froposal which is based on the removal of finger piers frcm an existing dock. One should notice that $t h \in$ term used in this section is "environmental conflict" rather than environmental impact. To assess the impacts of these or any coastal project is a complex and tedious process. It is by no means the intention of this study to conduct environmental impact analyses of the proposed alternatives. What can be accomplished, however, is an inventory or estimate of the instances where environmental issues are bound to be raised shculd the plan be scrutinized by governmental agencies. What we are attempting to demonstrate here is that the most obvious foints of environmental conflict can bo documented and their frequency of occurence from alternative to alternative can be used as an evaluation criterion. Those plans with fewer points of environmental conflict are therefore preferable.

\section{EVALUATION PROCESS}

The actual process cf compative evaluation translates the physical properties of the proposals into measurable criteria. Fiqure -12 illustrates how the afore mentioned informaticn for cost, level cf service, space and environmental conflict can be applied to each alternative to measure its suitability. 
Unier the cateqory of eccnomics, we have selected per slip cost and the cost ratio of site work as indicators of suitability. per slip cost, as discussed earlier, is a unit cost which characterizes the investment needed in marine structures and the relative likelihcod of adequate payback. The unit costs are ranked in $\$ 400$ increments for each alternative on a scale of 1 to 5. The cost ratio of site work has bean selected since it signifies the amount of the cotal development investment which is unlikely to produce a direct revonug return. This is to say that money spent on marine structures and shore facilities is likely to be income producing in the direct sense. Those proposals that minimize the dollar ratio cf site work are, therefore, believed to be preferable. In figure $\mathrm{C}-12$, the site work cost ratio is computed in increments of $5 \%$ on a scale of 1 to 5 .

The level of service which is proposed for each alternative is injicative of the ccmmercial competitiveness of the facility. Those alternatives having the greatest selection of services are therefore the mcst desirable. In the proposals. distribution of services ranged frow 6 to 15 and, as shown in Piqure c-12, the alternatives were ranked on a scale of 1 to 5 for service levels ranging from one to 15 functions.

Under the category of space, we have selected the land to water ratio as an indicator of spatial efficiency. It is our belief that those plans which have optimized the use of the land area will have land tc water ratics that are less than the accepted standard of 1:1. With waterfront land costs reaching $\$ 4.00$ and above per square foot, it behooves the planner to 
accommodate more boats with less real estate. The scale used in fiqure c-12 ranks the proposals from 1 to 5 , on a land to water ratio of $7: 1 . \mathrm{C}$ to $1.1: 1.0$.

The last ovaluative criterion is the expected incidence of environmental conflict. At the very least, each alternative will be confronted with one fermiting issue and in several cases, there are as many as five fotential areas of serious environmental issues. The Cataumet scenarios no. 2 and no.3 have multiple environmental issues particularly in connection with the dredginq, filling and excavation of Bed Brook. For this reason, these alternatives will come under significant pressure should they be subjected to the permitting process.

When all of the sccres for the various categories of comparison are displayed in watrix form, it becomes evident that some of the scenarios have a higher optimum value, under this evaluation system. This serves as a pointer for future study. Any more detailed analysis should use this as a startinq place, and concentrate on those alternatives with the hiqhest scores first. 
Figure $C-1$

COST ESTIMATE WORK SHEET

UNIT ${ }^{\frac{1}{*}}$ COSTS
LOCATION STONE COVE SCENARIO 1 A

\begin{tabular}{ll}
$\begin{array}{l}\text { COST } \\
\text { CATEGORIES }\end{array}$ & $\begin{array}{l}\text { UNIT * } \\
\text { COSTS }\end{array}$ \\
\hline SITE WORK & \\
Rip Rap & $\$ 20.00 / \mathrm{cy}$ \\
Evacuation & $3.00 / \mathrm{cy}$ \\
Fill & $2.00 / \mathrm{cy}$ \\
Dredging & $5.00 / \mathrm{cy}$ \\
Paving & $4.50 / \mathrm{sy}$ \\
Landscaping & $3.75 / \mathrm{sy}$
\end{tabular}

SCENARIO

COMMENTS \#⿰ OF UNITS ETC.

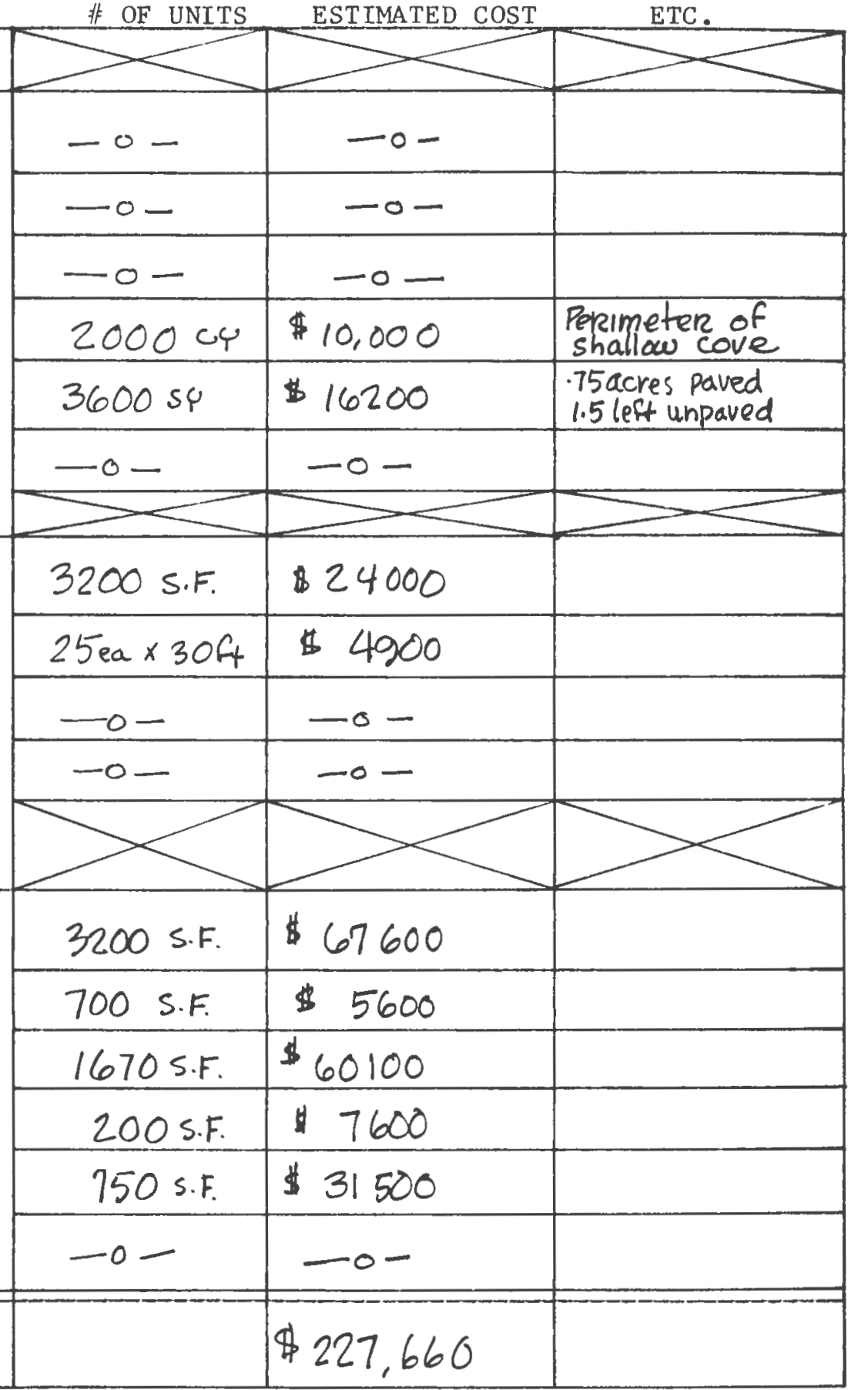

* cy - cubic yard

sy - square yard
$18.00 /$ s.f.

$8.00 /$ s.f.

$30.00 /$ s.f.

$38.00 /$ s.f.

$42.00 /$ s.f.

$40.00 /$ s.f.
TOTAL

s.f. - square foot

1.f. - linear foot vlf - vertical linear foot 
Figure

COST ESTIMATE WORK SHEET

\begin{tabular}{ll}
$\begin{array}{l}\text { COST } \\
\text { CATEGORIES }\end{array}$ & $\begin{array}{l}\text { UNIT * } \\
\text { COSTS }\end{array}$ \\
\hline Rip Rap WORK & $\$ 20.00 / \mathrm{cy}$ \\
Evacuation & $3.00 / \mathrm{cy}$ \\
Fill & $2.00 / \mathrm{cy}$ \\
Dredging & $5.00 / \mathrm{cy}$ \\
Paving & $4.50 / \mathrm{sy}$ \\
Landscaping & $3.75 / \mathrm{sy}$
\end{tabular}

LOCATION STONE COVE SCENARIO $1 b$.

\section{MARINE STRUCTURES}

Floating Docks

$7.50-10.15 /$ s.f.

SCENARIO \# OF UNITS

COMMENTS

\begin{tabular}{|c|c|c|}
\hline 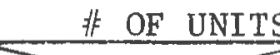 & ESTIMATED COS? & ETC. \\
\hline$\rightarrow<$ & $\rightarrow<$ & $\rightarrow$ \\
\hline$-0-$ & & \\
\hline$-0-$ & & \\
\hline$-0-$ & & \\
\hline$-0-$ & & \\
\hline 360054 & $\$ 16200$ & .74 Acres poved \\
\hline$-0-$ & & \\
\hline$\sum<$ & $6<$ & $S$ \\
\hline 800 S.F. & $\$ 6000$ & \\
\hline Gea $\times 30$ L.F. & $\$ 1200$ & \\
\hline 130 & $\$ 26000$ & \\
\hline$-0-$ & & \\
\hline 3200 S.F. & $\$ 67600$ & \\
\hline 700 S.F. & $\$ 5600$ & \\
\hline 1670 S.F. & $\$ 60100$ & \\
\hline 200 S.t. & $\$ 7600$ & \\
\hline 750 S.F. & $\$ 31500$ & \\
\hline$-0-$ & & \\
\hline & $\$ 221800$ & \\
\hline
\end{tabular}

TOTAL

$6.60 / \mathrm{vlf}$

Mooring Devices 200.00/ea.

Floating

150.00/1.f.

Breakwater

SHORE STRUCTURES

Service

18.00/s.f.

Storage

$8.00 /$ s.f.

Retail

$30.00 /$ s.f.

office

$38.00 /$ s.f.

Heads \& Showers

42.00/s.f.

Swimming pool

$40.00 / 3.5$

* cy - cubic yard

sy - square yard s.f. - square foot

1.f. - linear foot vlf - vertical linear foot 
Figure $\quad C-3$

COST ESTIMATE WORK SHEET

CATEGORIES

SITE WORK

Rip Rap

$\$ 20.00 / \mathrm{cy}$

Evacuation

$3.00 / c y$

Fi 11

$2.00 / \mathrm{cy}$

Dredging

$5.00 / c y$

Paving

Landscaping

$4.50 /$ sy

$3.75 / \mathrm{sy}$
LOCATION STONE COVE

SCENARto 2 A.

MARINE STRUCTURES

Floating Docks

$7.50-10.15 / \mathrm{s} . \mathrm{f}$.

SCENARIO

COMIENTS

非 OF UNITS ESTIMATED COST

ETC.

Piles

$6.60 / v 1 f$

Mooring Devices 200.00/ea.

Floating

$150.00 / 1 . \mathrm{f}$

Breakwater

SHORE STRUCTURES

Service

$18.00 /$ s.f.

Storage

$8.00 /$ s.f.

Retai 1

$30.00 /$ s.f.

office

$38.00 / s . f$

Heads \& Showers $42.00 /$ s.f.

Swimming Pool.

$40.00 / \mathrm{s} \cdot \mathrm{f}$

TOTAL

* cy - cubic yard

sy - square yard s.f. - square foot

1.f. - linear foot

\section{$\$ 341208$}




\section{Figure $-C-4$}

COST ESTIMATE WORK SHEET

\begin{tabular}{ll}
$\begin{array}{l}\text { COST } \\
\text { CATEGORIES }\end{array}$ & $\begin{array}{l}\text { UNIT * } \\
\text { COSTS }\end{array}$ \\
\hline SITE WORK & \\
\hline Rip Rap & $320.00 / \mathrm{cy}$ \\
Evacuation & $3.00 / \mathrm{cy}$ \\
Fill & $2.00 / \mathrm{cy}$ \\
Dredging & $5.00 / \mathrm{cy}$ \\
Paving & $4.50 / \mathrm{sy}$ \\
Landscaping & $3.75 / \mathrm{sy}$
\end{tabular}

MARINE STRUCTURES

Floating Docks 7.50-10.15/s.f.

Piles

$6.60 / v 1 f$

Mooring Devices 200.00/ea.

Floating

150.00/1.f.

Breakwater

SHORE STRUCTURES

Service

$18.00 /$ s.f.

Storage

$8.00 /$ s.f.

Retai 1

$30.00 /$ s. f.

Office

Heads \& Showers

$38.00 /$ s.f.

$42.00 /$ s.f.

Swimming Pool

TOTA L

* cy - cubic yard

sy - square yard

$40.00 /$ s.f.
LOCATION STONE COVE

SCENARIO $2 B$

SCENARIO

非 OF UNITS ESTIMATED COST

COMMENTS

ETC. 
Figure $c-5$

COST ESTIMATE WORK SHEET

LOCATION JTONE COVE SCENARIO 3

\begin{tabular}{ll}
$\begin{array}{l}\text { COST } \\
\text { CATEGORIES }\end{array}$ & $\begin{array}{l}\text { UNIT } * \\
\text { COSTS }\end{array}$ \\
\hline SITE WORK & \\
Rip RaP & $20.00 /$ cy \\
Evacuation & $3.00 / c y$ \\
Fil1 & $2.00 / \mathrm{cy}$ \\
Dredging & $5.00 / \mathrm{cy}$ \\
Paving & $4.50 / \mathrm{sy}$ \\
Landscaping & $3.75 / \mathrm{sy}$
\end{tabular}

MARINE STRUCTURES

Floating Docks 7.50-10.15/s.f.

SCENARIO 非 OF UNITS ESTIMATED COST

COMMENTS ETC.

Piles

$6.60 / v 1 f$

Mooring Devices 200.00/ea.

Floating

150.00/1.f.

Breakwater

SHORE STRUCTURES

Service

$18.00 /$ s.f.

Storage

$8.00 /$ s.f.

Retail

$30.00 /$ s. f.

of fice

$38.00 /$ s.f.

Heads \& Showers

$42.00 /$ s.f.

Swimming Pool

$40.00 /$ s.f.

TOTA L

* cy - cubic yard

sy - square yard

s.f. - square foot

1.f. - linear foot
$\$ 844567$

vlf - vertical linear foot 
Figure 66

COST ESTIMATE WORK SHEET

CATEGORIES

SITE WORK

Rip Rap

Evacuation

Fi11

Dredging

Paving

Landscaping

MARINE STRUCTURES

Floating Docks

Piles

Mooring Devices

Floating

Breakwater

SHORE STRUCTURES

Service

Storage

Retail

Office

Heads \& Showers

Swimming Pool

$\$ 20.00 / c y$

$3.00 / c y$

$2.00 / c y$

$5.00 / \mathrm{cy}$

$4.50 /$ sy

$3.75 / \mathrm{sy}$

LOCATION CATAUMET SCENARIO 1

SCENARIO COMMENTS

非 OF UNITS

ETC.

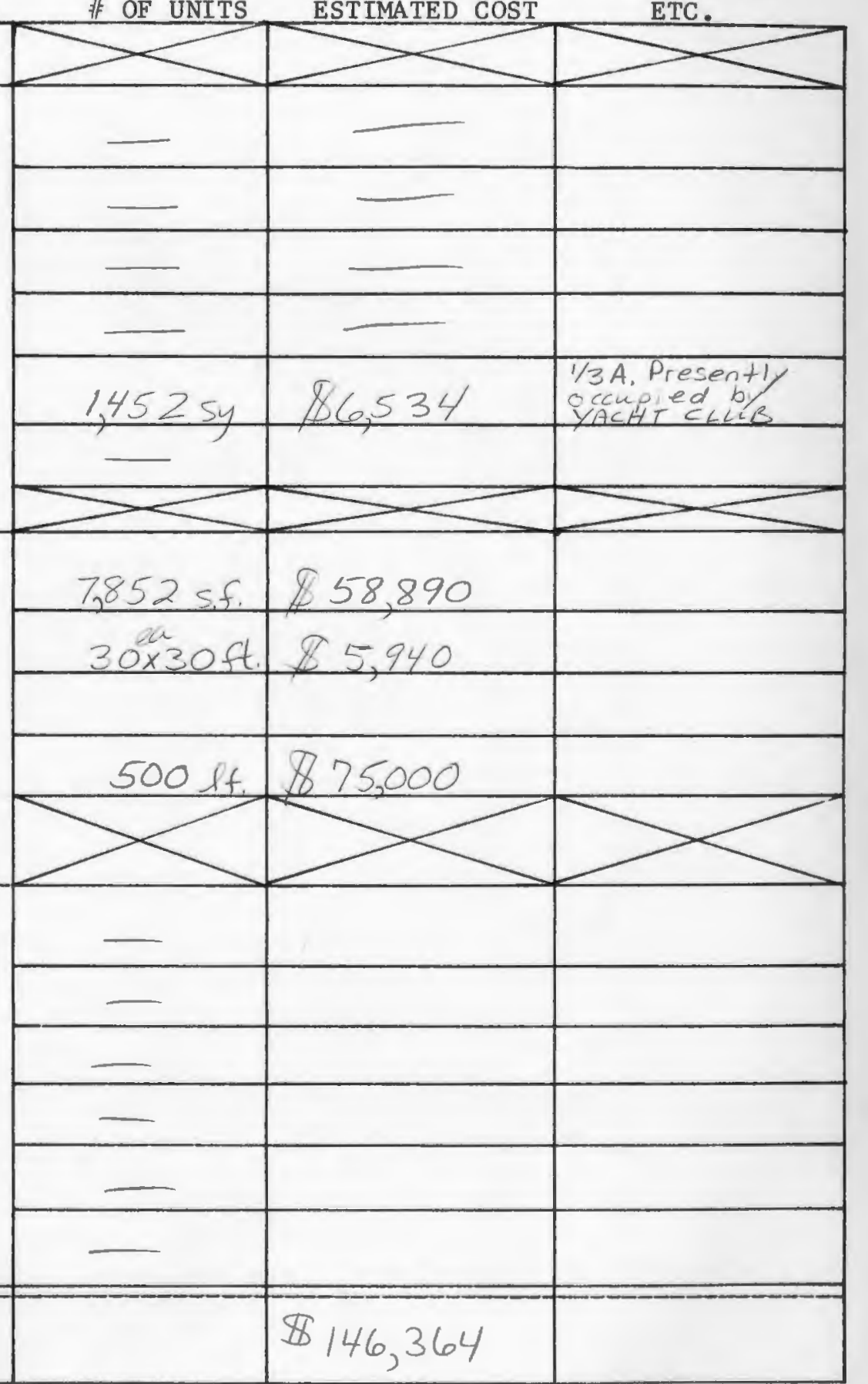

* cy - cubic yard
sy - square yard

s.f. - square foot

vlf - vertical linear foot

1.f. - linear foot

(1) NIEL ROSS

1979 


\section{Figure $C 7$}

COST ESTIMATE WORK SHEET

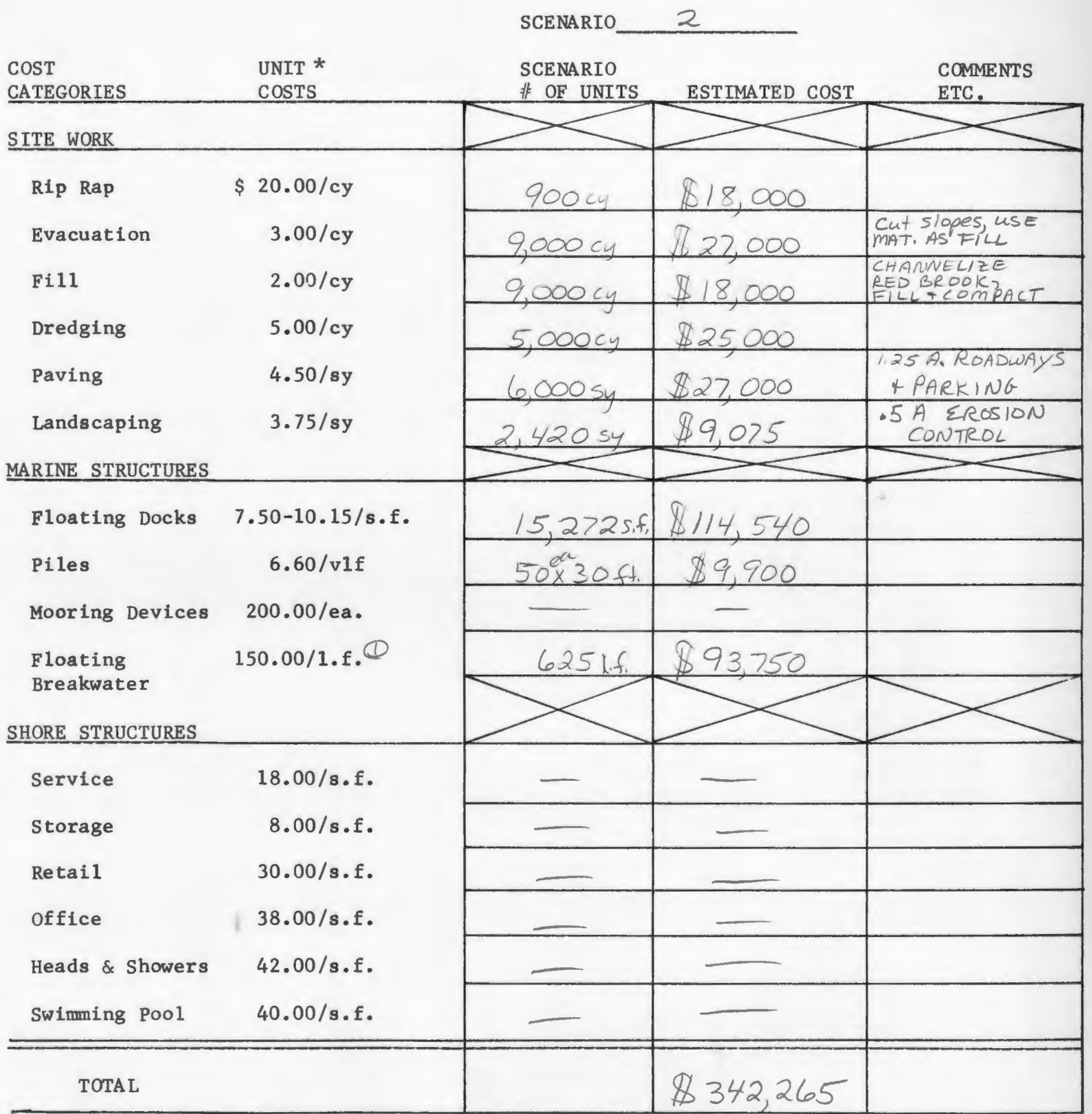

* cy - cubic yard

sy - square yard s.f. - square foot

1.f. - linear foot vlf - vertical linear foot

(1) Personal Communication W/NIEL ROSS $12 / 79$

Source: Bender \& Winsor 


\section{Figure $C 8$}

COST EST MATE WORK SHEET

\begin{tabular}{lc}
$\begin{array}{l}\text { COST } \\
\text { CATEGORIES }\end{array}$ & $\begin{array}{c}\text { UNIT * } \\
\text { COSTS }\end{array}$ \\
\hline SITE WORK & \\
\hline Rip Rap & $\$ 20.00 / \mathrm{cy}$ \\
Evacuation & $3.00 / \mathrm{cy}$ \\
Fil1 & $2.00 / \mathrm{cy}$ \\
Dredging & $5.00 / \mathrm{cy}$ \\
Paving & $4.50 / \mathrm{sy}$ \\
Landscaping & $3.75 / \mathrm{sy}$
\end{tabular}

LOCATION CATAUMET

SCENARIO 3

\section{MARINE STRUCTURES \\ Floating Docks $7.50-10.15 /$ s.f. \\ Piles $\quad 6.60 / v 1 f$ \\ Mooring Devices 200.00/ea. \\ Floating $\quad 150.00 / 1 . f$. (1) \\ Breakwater}

SCENARIO COMMENTS 非 OF UNITS ESTIMATED COST ETC.

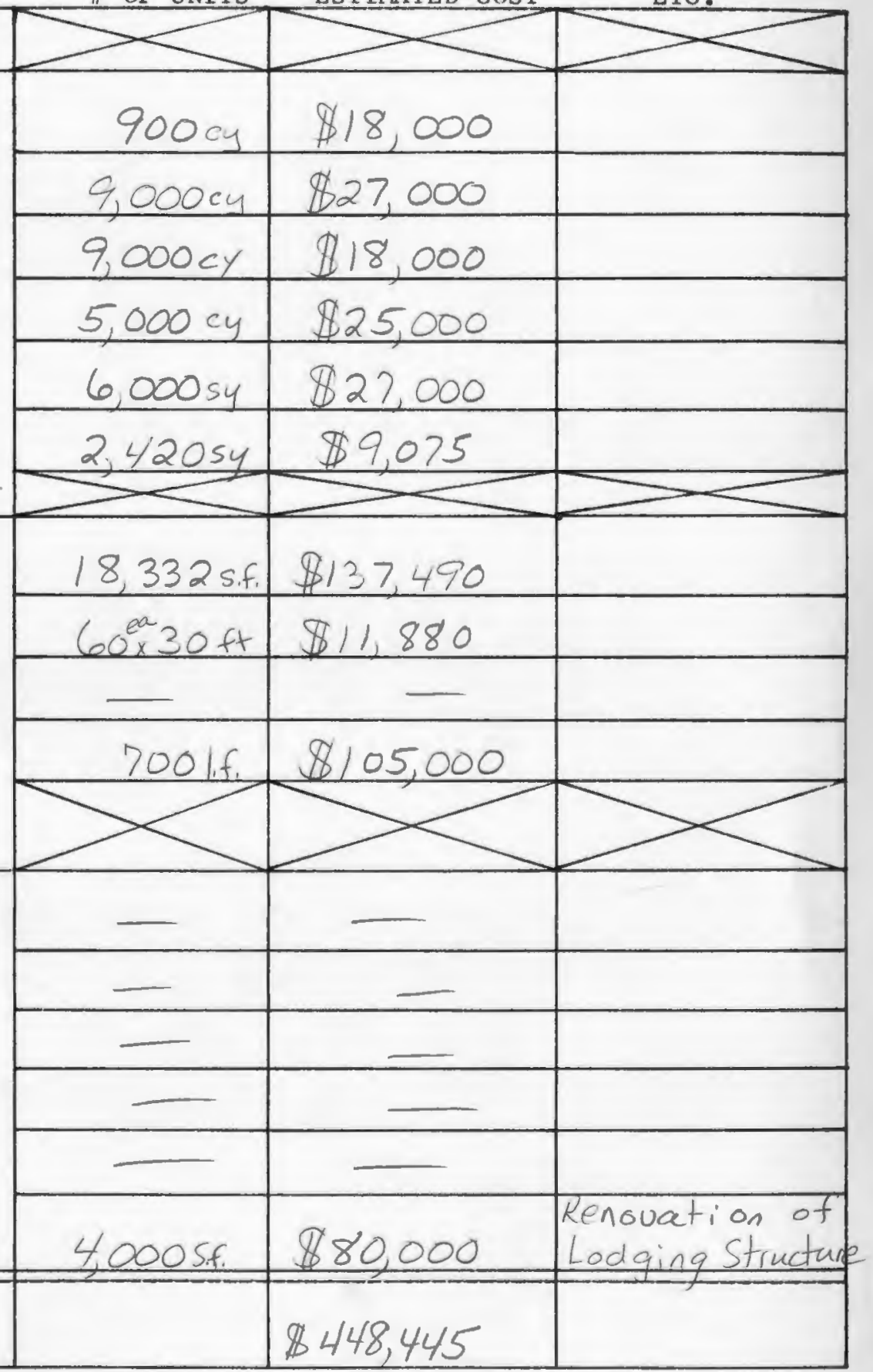

* cy - cubic yard

sy - square yard
$18.00 / s . f$.

$8.00 /$ s.f.

$30.00 /$ s.f.

$38.00 /$ s.f.

42.00/s.f. $20.00 / 5$. F
TOTAL

Heads \& Showers

OTHER

stitning

\subsection{0 f.}


COST COMPARISON OF DEVELOPMENT ALTERNATIVES

\begin{tabular}{|c|c|c|c|c|c|c|c|c|}
\hline & $\begin{array}{l}\text { STONE } \\
\text { COVE } \\
\text { la }\end{array}$ & $\begin{array}{l}\text { STONE } \\
\text { COVE } \\
\text { lb }\end{array}$ & $\begin{array}{l}\text { STONE } \\
\text { COVE } \\
2 \mathrm{a} \\
\end{array}$ & $\begin{array}{l}\text { STONE } \\
\text { COVE } \\
2 \mathrm{~b} \\
\end{array}$ & $\begin{array}{l}\text { STONE } \\
\text { COVE } \\
3 \\
\end{array}$ & $\begin{array}{c}\text { CATAUMET } \\
1 \\
\end{array}$ & $\begin{array}{c}\text { CATAUMET } \\
2 \\
\end{array}$ & $\begin{array}{c}\text { CATAUMET } \\
3 \\
\end{array}$ \\
\hline Estimated Cost & $\$ 227,660$ & $\$ 221,800$ & $\$ 341,208$ & $\$ 375,800$ & $\$ 844,567$ & $\$ 146,364$ & $\$ 342,265$ & $\$ 448,445$ \\
\hline $\begin{array}{l}\text { Total shore } \\
\text { Facilities Added }\end{array}$ & $6520 \mathrm{sf}$ & $6520 \mathrm{sf}$ & $16425 \mathrm{sf}$ & 24925 sf & 33075 sf & $-0-$ & $-0-$ & $-0-$ \\
\hline Added Slips & 33 & 52 & 85 & 16 & 173 & 49 & 87 & 92 \\
\hline Total Boats & 170 & 189 & 222 & 233 & 310 & 279 & 322 & 388 \\
\hline Cost Per Slip & $\$ 877$ & $\$ 638$ & $\$ 756$ & $\$ 1734$ & $\$ 1825$ & $\$ 2853$ & $\$ 2508$ & $\$ 2765$ \\
\hline Site Work & $\$ 26,200$ & $\$ 16,200$ & $\$ 26,698$ & $\$ 29,800$ & $\$ 59,607$ & $\$ 6,534$ & $\$ 124,075$ & $\$ 124,075$ \\
\hline Marine Structures & $\$ 28,950$ & $\$ 33,200$ & $\$ 64,260$ & $\$ 27,750$ & $\$ 315,870$ & $\$ 139,830$ & $\$ 218,190$ & $\$ 254,370$ \\
\hline $\begin{array}{l}\text { Shore Structures } \\
\text { Cost_Ratios }\end{array}$ & $\$ 172,400$ & $\$ 172,400$ & $\$ 250,250$ & $\$ 318,250$ & $\$ 469,090$ & $-0-$ & $-0-$ & $-0-$ \\
\hline Sitework/Total & $12 \%$ & $7 \%$ & $9 \%$ & $8 \%$ & $7 \%$ & $4 \%$ & $36 \%$ & $28 \%$ \\
\hline Marine Struc./Tota 1 & $13 \%$ & $15 \%$ & $19 \%$ & $7 \%$ & $37 \%$ & $96 \%$ & $64 \%$ & $72 \%$ \\
\hline Shore Struc./Total & $75 \%$ & $78 \%$ & $73 \%$ & $85 \%$ & $56 \%$ & $-0-$ & $-0-$ & $-0-$ \\
\hline
\end{tabular}




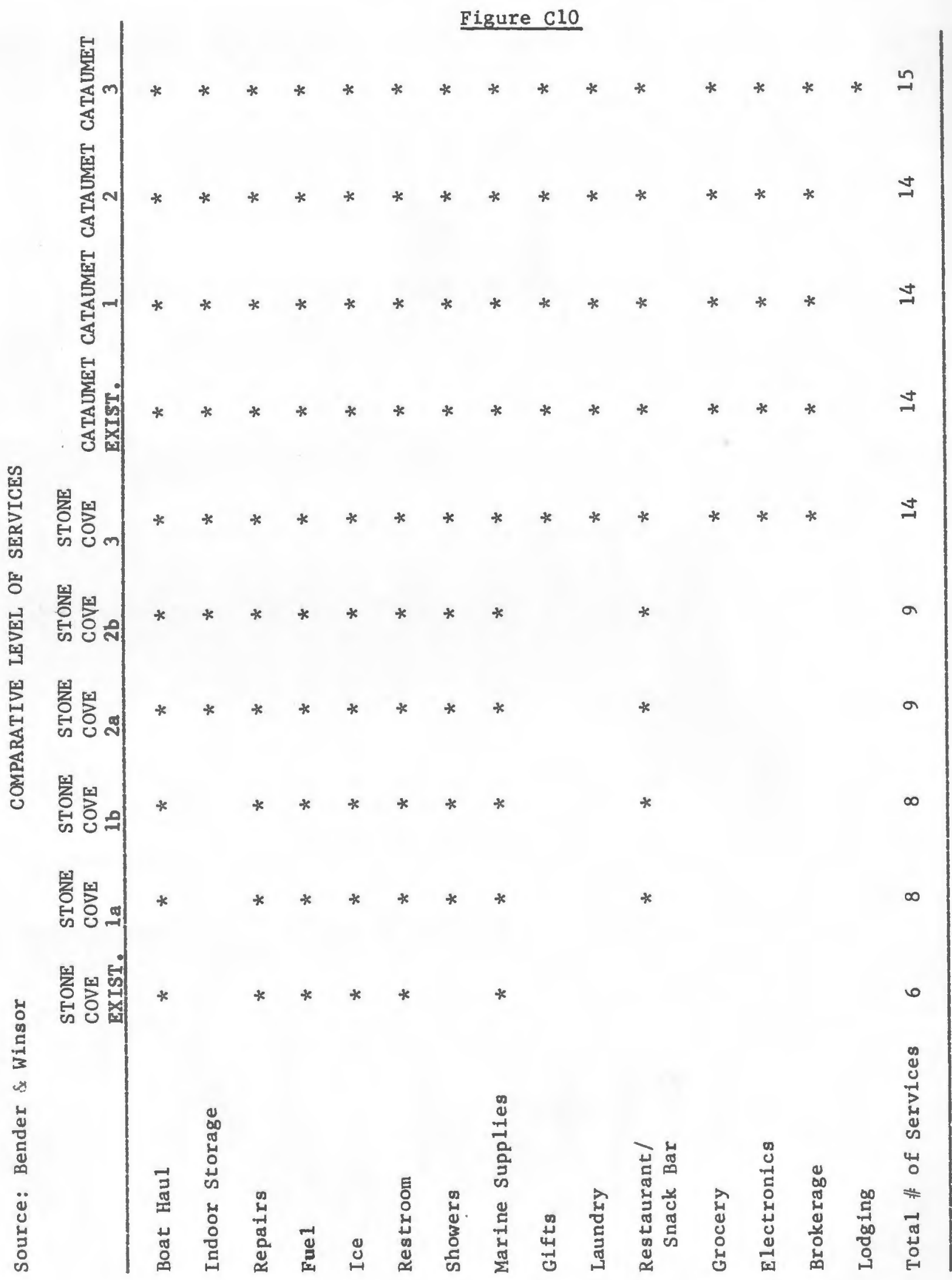




\section{Figure Cl1}

SPACE: LAND / WATER RATIO

\begin{tabular}{lcccccc}
$\begin{array}{l}\text { STONE } \\
\text { COVE }\end{array}$ & EXISTING & $\begin{array}{c}\text { SCENARIO } \\
1 \mathrm{a}\end{array}$ & $\begin{array}{c}\text { SCENARIO } \\
1 \mathrm{~b}\end{array}$ & $\begin{array}{c}\text { SCENARIO } \\
2 \mathrm{a}\end{array}$ & $\begin{array}{c}\text { SCENARIO } \\
2 \mathrm{~b}\end{array}$ & $\begin{array}{c}\text { SCENARIO } \\
3\end{array}$ \\
\hline & $.83: 1.0$ & $.83: 1.0$ & $.93: 1.0$ & $.78: 1.0$ & $.78: 1.0$ & $.68: 1.0$ \\
& & & & & \\
CATAUMET & EXISTING & $\begin{array}{c}\text { SCENARIO } \\
1\end{array}$ & $\begin{array}{c}\text { SCENARIO } \\
.2\end{array}$ & $\begin{array}{c}\text { SCENARIO } \\
3\end{array}$ \\
\hline & $1.2: 1.0$ & $1.0: 1.0$ & $.98: 1.0$ & $1.11: 1.0$
\end{tabular}

Source: Bender \& Winsor 
COMPARATIVE EVALUATION OF DEVELOPMENT SCENARIOS

\begin{tabular}{|c|c|c|c|c|c|c|c|c|}
\hline . & $\begin{array}{l}\text { STONE } \\
\text { COVE } \\
\text { la }\end{array}$ & $\begin{array}{l}\text { STONE } \\
\text { COVE } \\
\text { Lb } \\
\end{array}$ & $\begin{array}{l}\text { STONE } \\
\text { COVE } \\
2 a \\
\end{array}$ & $\begin{array}{l}\text { STONE } \\
\text { COVE } \\
2 b \\
\end{array}$ & $\begin{array}{l}\text { STONE } \\
\text { COVE } \\
3 \\
\end{array}$ & $\begin{array}{c}\text { CATAUMET } \\
1 \\
\end{array}$ & $\begin{array}{c}\text { CATAUMET } \\
2 \\
\end{array}$ & $\begin{array}{c}\text { CATAUMET } \\
3 \\
\end{array}$ \\
\hline cosT & & & & & & & & \\
\hline Per slip & 5 & 5 & 5 & 3 & 2 & 1 & 1 & 1 \\
\hline $\begin{array}{l}\text { Cost Ratio } \\
\text { Site work }\end{array}$ & 3 & 4 & 4 & 4 & 4 & 5 & 1 & 1 \\
\hline \multicolumn{9}{|l|}{ SERVICE } \\
\hline Level of Service 3 & 2 & 3 & 3 & 3 & 5 & 5 & 5 & 5 \\
\hline \multicolumn{9}{|l|}{ SPACE } \\
\hline Land/Water Ratio 4 & 4 & 3 & 4 & 4 & 5 & 2 & 3 & 1 \\
\hline \multicolumn{9}{|c|}{ ENVIRONMENTAL CONFLICT } \\
\hline $\begin{array}{l}\text { Points of } 5 \\
\text { Potential Conflice }\end{array}$ & 4 & 5 & 4 & 4. & 1 & 5 & 1 & 1 \\
\hline TOTAL SCORE & 18 & 20 & 20 & 18 & 17 & 18 & 11 & 9 \\
\hline
\end{tabular}

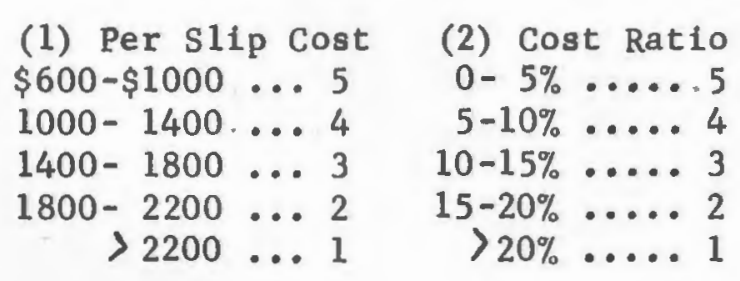

(3) Service

$1-3 \ldots 1$

$4-6 \ldots 2$

$7-9 \ldots 3$

$10-12 \ldots 4$

$13-15 \ldots 5$
(4) Space/Water Ratio $.7: 1.0 \ldots 5$

$.8: 1.0 \ldots .4$

$.9: 1.0 \ldots .3$

$1.0: 1.0 \ldots 2$

$1.1: 1.0 \ldots 1$
(5) Environmental conflict

$$
\begin{array}{rrr}
1 & \ldots & 5 \\
2 & \ldots & 4 \\
3 & \ldots & 3 \\
4 & \ldots & 2 \\
>5 & \ldots & 1
\end{array}
$$


THE PEEHIT PROCESS

A marina owner attempting to modify or expand his/her facility quickly runs into what appears to be an endless wall of requlatory red tape. Permits and approvals must be obtained, in the proper order, from a bewildering number of aqencies and individuals. If anycne objects to the expansion plans, one or more public hearings must be held. The process can become quite lengthy, taking months, or even more than a year. The requlatory frocess, as unorganized as it may seem on a lay to day level, does make some theoretical sense. As society and technology become increasingly complex, the numbers of forces at work in any situation become greater. No watter what one tries to do, in terms of altering the landscape, someone is qoing to object to it. Usually, all sides will have a point of view, and, usually, most sides will have at least one valid comment. There no right answer.

The requlatory process has been set up in an attempt to see that all voices are heard, and that a reasonable solution is reacher. In the permit prccess for alterations of the coastal environment, this is reflected in bargaining during the permit application procedure. In Rhode Island, very few permits are denied, but very few are approved in their original form: the key word is "modificaticn".

Part of the reason for confusicn when first approaching the permit process is that the permit system has little of the 
loqic of the oriqinal laws left visible and apparent. Typically, a simple idea, such as to preserve and enhance the natural environment, is proposed in the Congress. During the political barqaining process, the law (if it passes) becomes qreatly modified. An aqency is created or designated to implemont the law, and the agency in turn promulgates requlations. Government aqencies generally undergo a slow but constant process of reorganizaticn. In addition, regulations are qradually but constantly being updated. It is within this chanqing rrocess of update and reorganize that the permit process takes place - hence the confusion for anyone who does not keep track of government regulations for fun or profit. This section qives a brief history and overview of the current permit process in Rhode Island and Massachusetts. Hithout qoing into detail (there is plenty of that available), the permit process for each state is discussed.

There are three levels of government involved in the permit process: local, state, and federal. In addition to local ordinances concerning land use and zoning, and state requlations such as building codes, a series of more specific ordinances have emerged during the last ten years. These consist of wetlands regulations, special area designations, and the 1ike. The overall imfetus for these has cone fron the Federal level down, however, with distribution of federal funding to states and towns used for leverage. Most of this is a result of the envircnmental movement, the force it gained in the lato sixties, and the resulting legislation that emerged in the early seventies. A brief look at this legislation shows 
who the actors are in the coastal zone permit process, and why.

There are five inpcrtant pieces of legislation involved:

1 - The Rivers and Harbors act of 1899. which traditionally involved the Army Corps of Engineers in permitting procedures for all "navigable waters" in the country. In the early seventies a series of court cases dramatically broadened the concept of "naviqability", and involved the corps in environmental requlation as well.

2 - The National Environmental Policy Act of 1969. (NEPA) which was (and is) ar unprecedentedly broad piece of leqislation requiring an environmental impact statement (EIS) for everp "major" federally funded project. NEPA quickly changed the functicns of almost every law and agency dealing with any sort of research or construction project. NEPA had a large role in forcing the brcader role of the Army corps. A swara of "little NEPAS" were hatched by many states, including Massachusetts. The Massachusetts Environmental Policy Act plays a part in the peruit frccess in that state.

3 - The Federal water polluticn Control Act Amendments of 1972 (PMPCA). which regan a trcad program involving the Pederal and state governments to clean up the nation's waters. This involves many agencies of government, the wost visible being the Corps, the Envircnmental Frotection Agency, and in the case of marinas, the U.S. CCAST GUARE. The most visible results are the sewage treatment plants now going into operation along the coast, and the quandary about what to do with wastes from boat toilets. 
4 - The Marine protection, Fesearch, and Sanctuaries Act of 1972. Which is commonly known as the ocean dumping act, as one of its main purposes is to regulate duming of dredged materials and wastes in federal waters. Once again the Corps is the lead federal agency.

5 - The Coastal Zone Managerent Act of 1972 (CZMA), Which brought all of these acts, and cthers, together in an effort to provide for effective planning and regulation of activities in the coastal zcne. Each ccastal state was required to develop a Coastal Zone Management plan, and have it approved ty the Federal Government. The czMA provides for consistency of requlations among all aqencies involved, to avoid potential conflict. Bhode Island and Massachusetts took different approaches to iuplementing a Ccastal zone Management plan, and the permit process differs as a result. In Rhode Island, the Coastal Resources Management Council (CRMC) is the main agency one deals with during the permit process, where in Massachusetts the town/city Conservation comission plays a larqe role, alcng with the Defartment of Environmental Quality Engineerinq.

Piqure $\mathrm{E} 1$ shows the permit process in a simplified form. The first step is to complete all requirements at the local level. Yhen these bave been satisfied, applications are made to the state and Federal aqencies, at about the same time. The state and Federal applications are parallel, not sequential. many of the requirements are similar, and an exchange of information often takes place between state and Pederal 
aqencies.

The process at the local level in Rhode Island is shown in Fiqure E2. The local qovernment must be approached in the same way as it would for anp construction project. A site plan must be prəpared, a building permit obtained, any necessary zoning chanqes or variances approved, open space ordinances complied with, etc. Two divisions of the Department of Environmental Management (DEM) may become involved. The Division of coastal Resources must check to see that state Building codes are complied with, and if a serage disfosal system is part of the construction, an Individual sewage Disposal systen, (ISDS) permit must be obtained. Pinally the town council lor whatever qroup has the final authcrity) most approve the project. After all local requirements have been met, application is made to the CRMC for a permit at the state level. The organization of the CRMC is shown in Pigure E3. Staff support is provided by the statewide Planing program, for consistency with other State and Federal programs. The DEM provides scientific. planning, engineering, and enforcement staff, and is the main state aqency involved in day-to-day permit procedures. Figure E4 shows the application process. After the application is recieved, public notice is sent out to all agencies and individuals who miqht be concerned. The public can see copies at thoir center of lccal government (town hall, etc.). The application is reviewed for 30 days by statewide planning and the appropriate departments of DEM, as well as any interested parties. If there is no objection, the proposal is reviewed by the full council. Scme modification of the proposal may be 
required, or additional evidence sought, before the CRMC makes a final decision. The permit is then either approved or denied. In the case of denial, the applicant is entitled to fudicial review. In most cases of judicial review of agencies, the CRMC included, the courts tend to stick to questions of law rather than questions of fact. That is, the court will not question the judgement of the agency as to whether the permit should be denied or affrcved. Rather, the court will look to see that all of the correct frocedural requirements have been met during the pernit review process. If the procedure is correct, an abuse of discretion on the part of the agency must be shown, gererally that the agency was "unreasonable" or "arbitrary and capricious" (depending on the applicable statutel in its decision. The burden of proof is on the applicant, not on the agency.

As the state process is going on, so is the Federal process of the Army corps. The process is very sinilar to the Rhode Island state process, and is outlined in Pigure E6. Public notice is posted, comment is solicited during a 30 day review period, there is a public hearing if there are any objections, the corps makes a final evaluation, and the permit is either approved or denied. This duflication of effort makes sense in that the state and the corps are looking for different things, because of the different laws affecting each. It makes less sense from the point of view of the applicant, hovever, and efforts are underway to inteqrate these parallel processes into one coordinated fermittirq procedure. 
In Massachusetts, the Federal prccess is the same, and goes on parallel to the state process, just as in Bhode Island. But the local and state process is somewhat different. The local Conservation commission in each town or city is the lead agency for the permit process. Various state government agencies beccme involved as the intended sccpe of the project becomes larqer. There are "threshold" reguirements in the regulations, beyond wich certain state agencies must review the application. Below these thresholds the decision-making renains at the local level. Figure E6 shows the local permitting process. After all town requirements have been met. the Division of Envircamental Impact Review of the Executive office of Envircnmental Affairs (EOBA) evaluates the proposal. This state Division is often called the "MEPA unit", as its function is to evaluate project proposals of almost any sort under the Massachusetts Environmental Protection Act. The MEPA review ranges from routine to complex, as the scope and probable impact of the propcsal increase. The permit process then passes cn to the state level cnce the requirements of MEPA have been satisfied, involving further state agencies as necessary.

Fiqure 27 shows the structure of the EOEA. The principal aqency involved, besides the MEPA unit, is tho Department of Environmental Quality Engineering (DECE). Three principal divisions are involved, depending on the type of project. These are the Divisicn of Land and Hater Use, the Division of Air and Hazardous Materials, and the Division of Hater pollution control. The overall state/local permit process is 
shown in Figure E8. The DECE Begional Engineer is the lead aqent for the state, and the Conservation Comission represents local government. The crder of conditions specifies any modificaticns necessary for permit approval. Staff support is provided by the four EOEA qroups shown at the extreme left. A hearing is held by the ccnservation comission, any final modifications necessary are made, and the permit is granted or denied. Judicial review is available at this point, just as in Rhode Island, in the case of peruit denial.

Hopefully, this brief outline shows that the permit process is not the overly ccrplicated bureaucratic hassle it first appears to be. Purther information is available from the local and State agencies listed in Figure F9. In both Rhode Island and Massacusetts, the Coastal Zone Management Plan and Final Environmental Impact statement is a good scurce for most of the needed information. Copies of these plans are generally available for insfecticn and use at town halls and libraries in both states. 
Figure E2

R. I. LOCAL GOVERNMENT

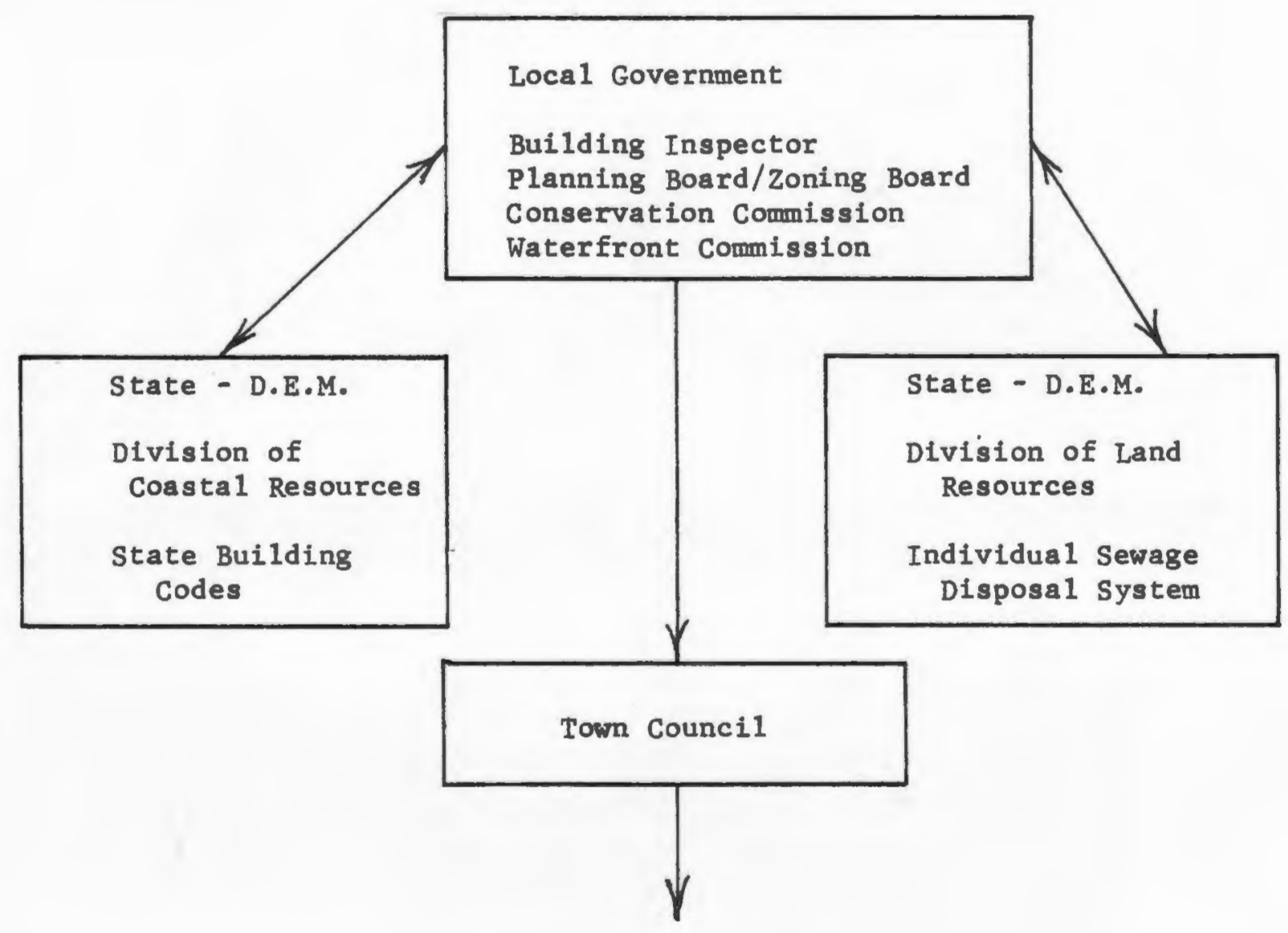


Figure E1

PERMIT PROCESS

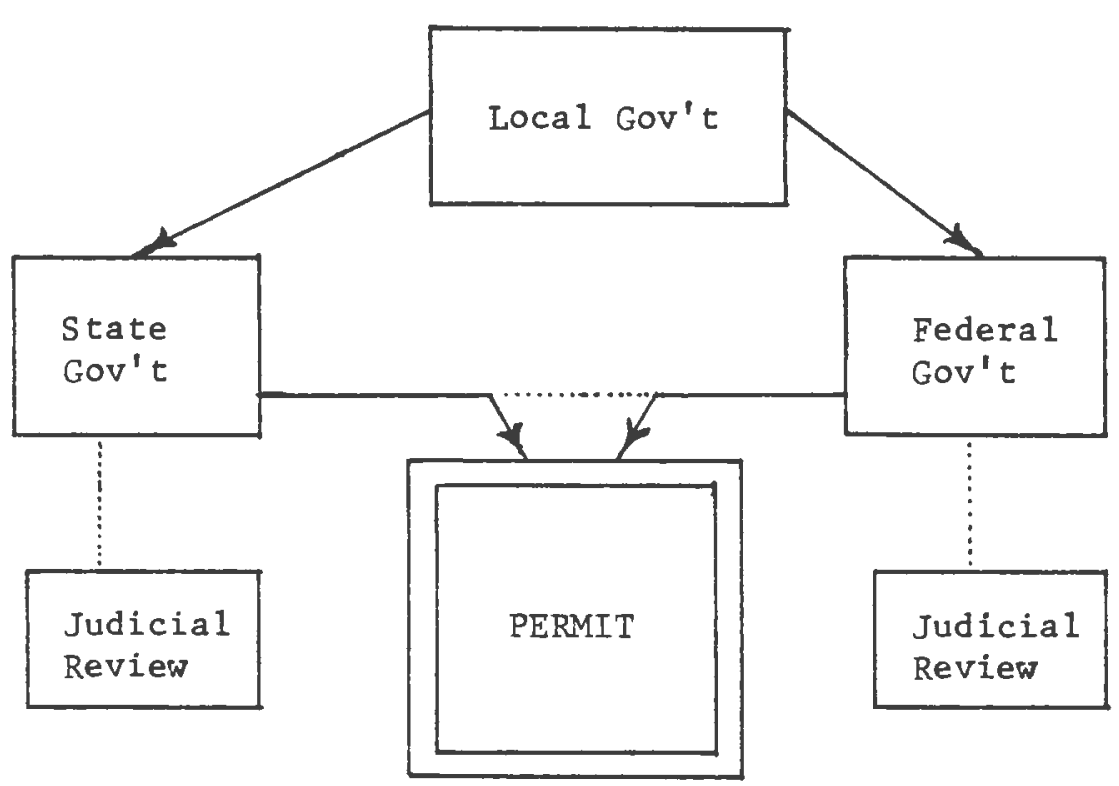

Main Sources: State of Rhode Island Coastal Management Program and Final EIS, 1979

Appendix B, pp. 275-288

The Rhode Island Coastal Resources Management

Program: A Handbook for Permit Applications, 1978

MASS: Massachusetts Coastal Zone Management Program and Final EIS, 1978

CORPS: U.S.Army Corps of Engineers Permit Program: A Guide for Applicants, 1978 


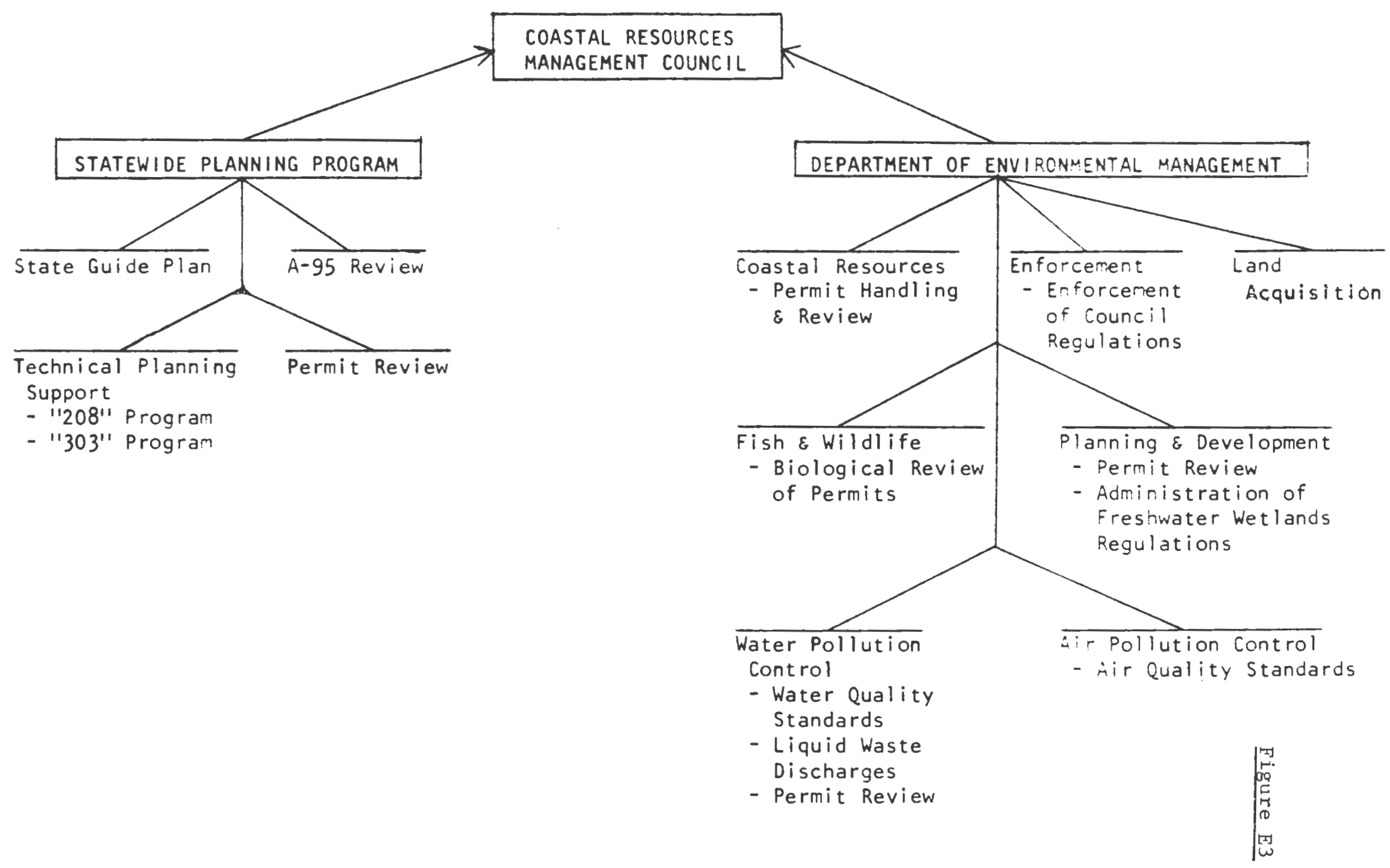

Source: State of Rhode Island Coastal Management Program and Final Environmental Impact Statement, 1978 


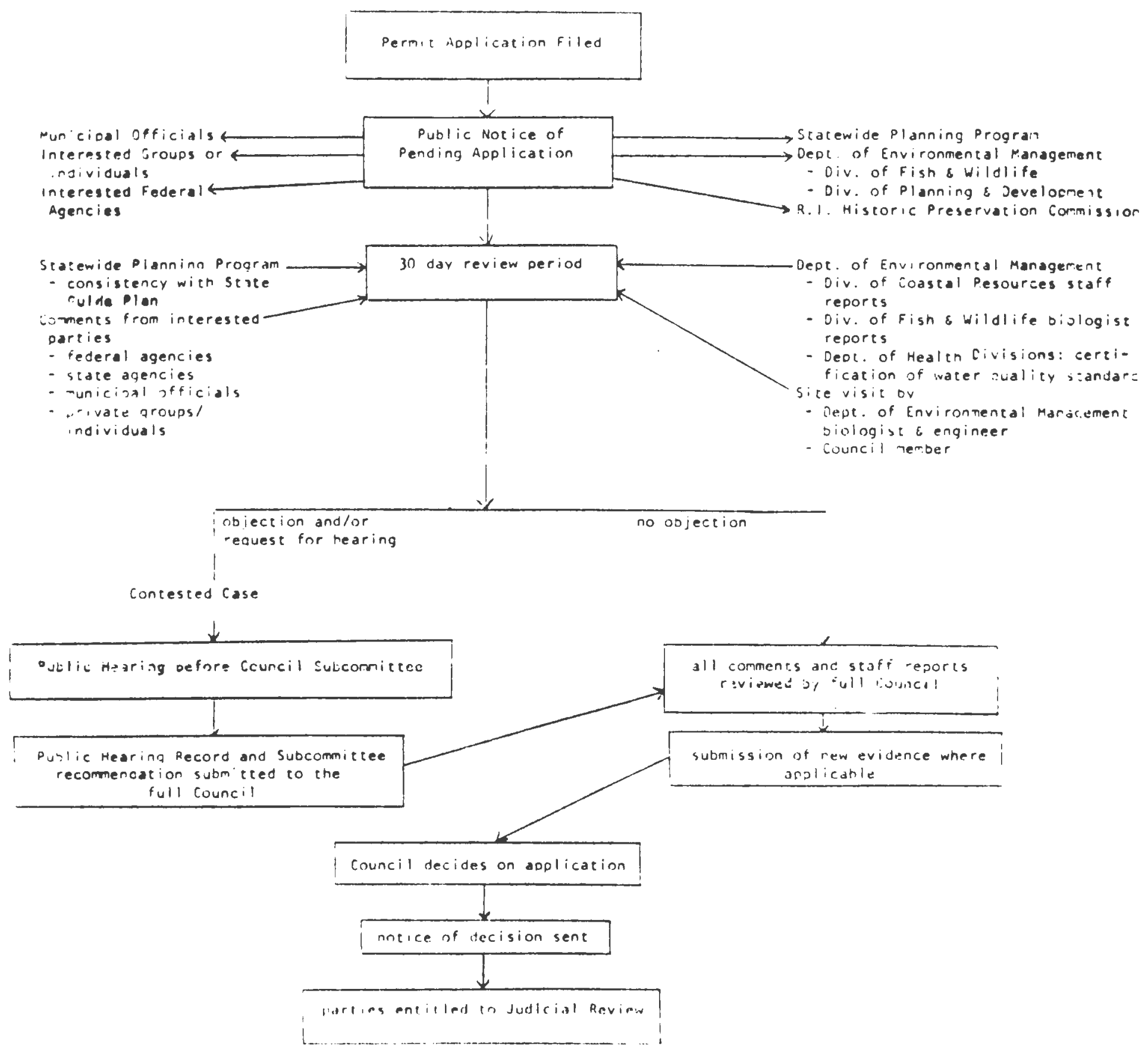

Source: State of Rhode Island Coastal Management Program and Final Environmenta1 Impact Statement, 1978 


\section{Figure E5}

\section{typical corps permit review process}

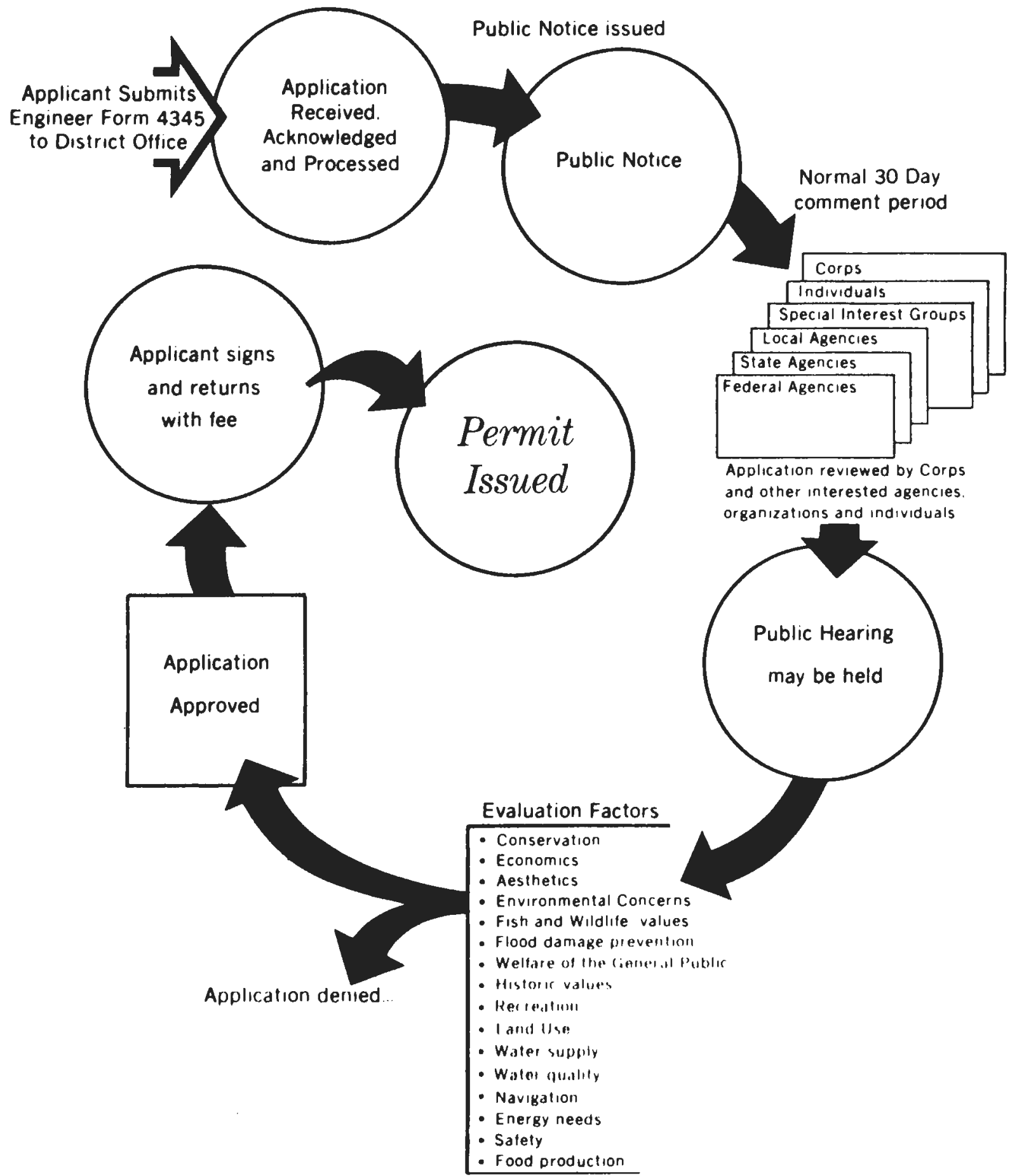

Source: U.S.Army Corps of Engineers Permit Program:

A Guide for Applicants, 1978 


\section{Figure E6}

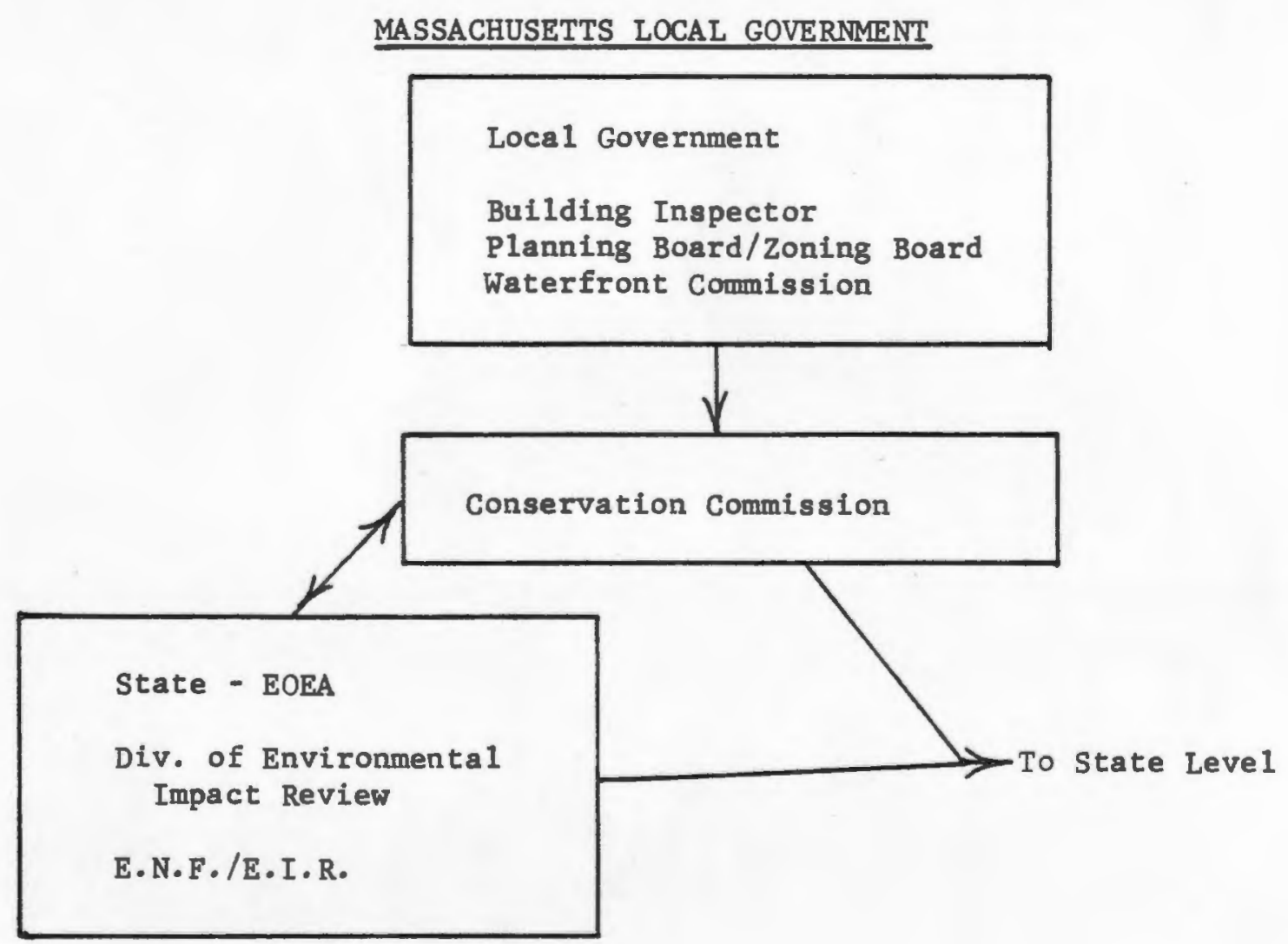




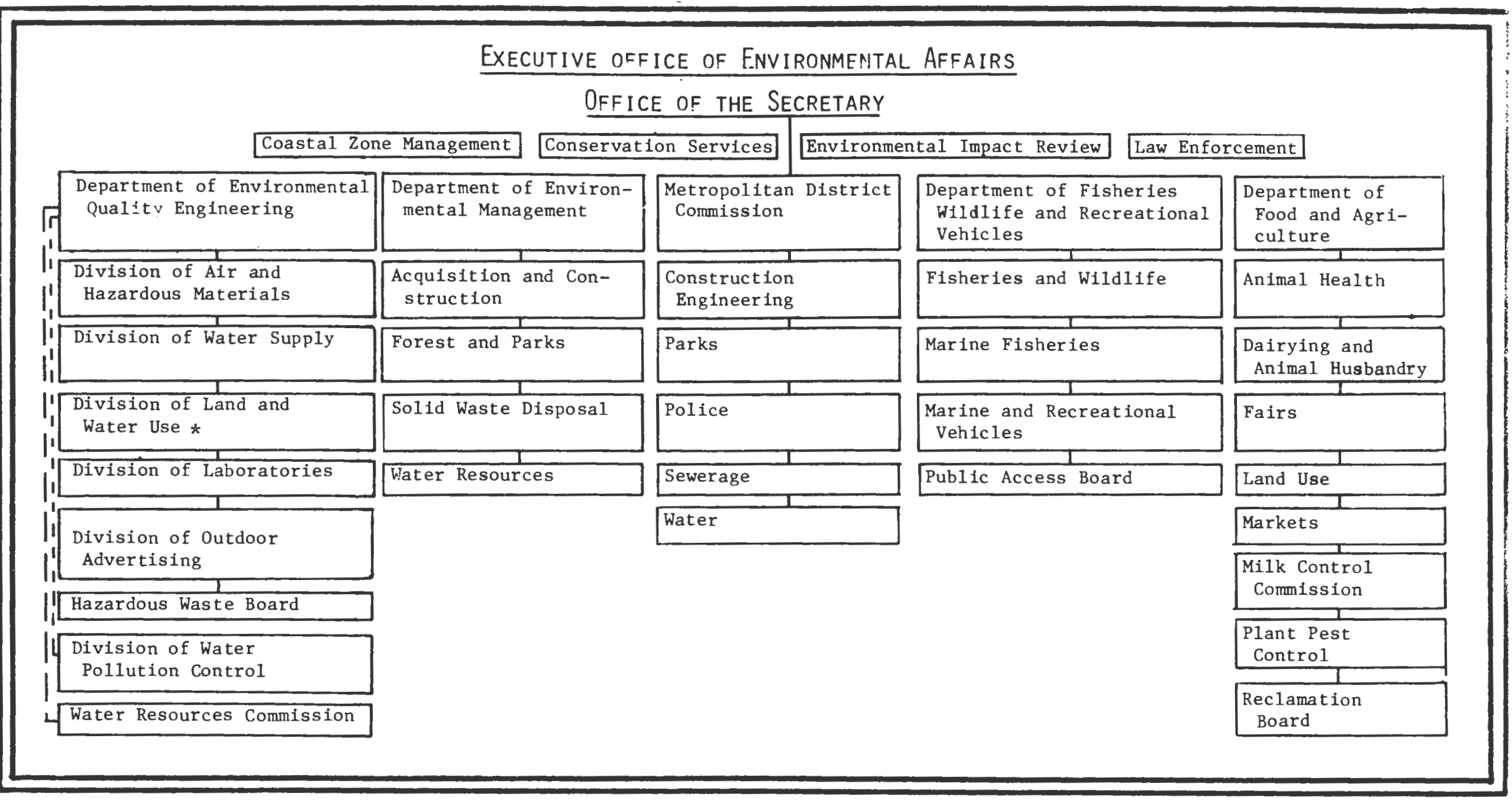

* Includes Wetlands, Waterways, and Mineral Resources Programs

Source: Massachusetts Coastal Zone Management Program and Final Environmental Impact Statement, 1978 
Figure E8

PROCESS FOR WATERWAYS LICENSE AND WETLANDS PROTECTION PERMIT

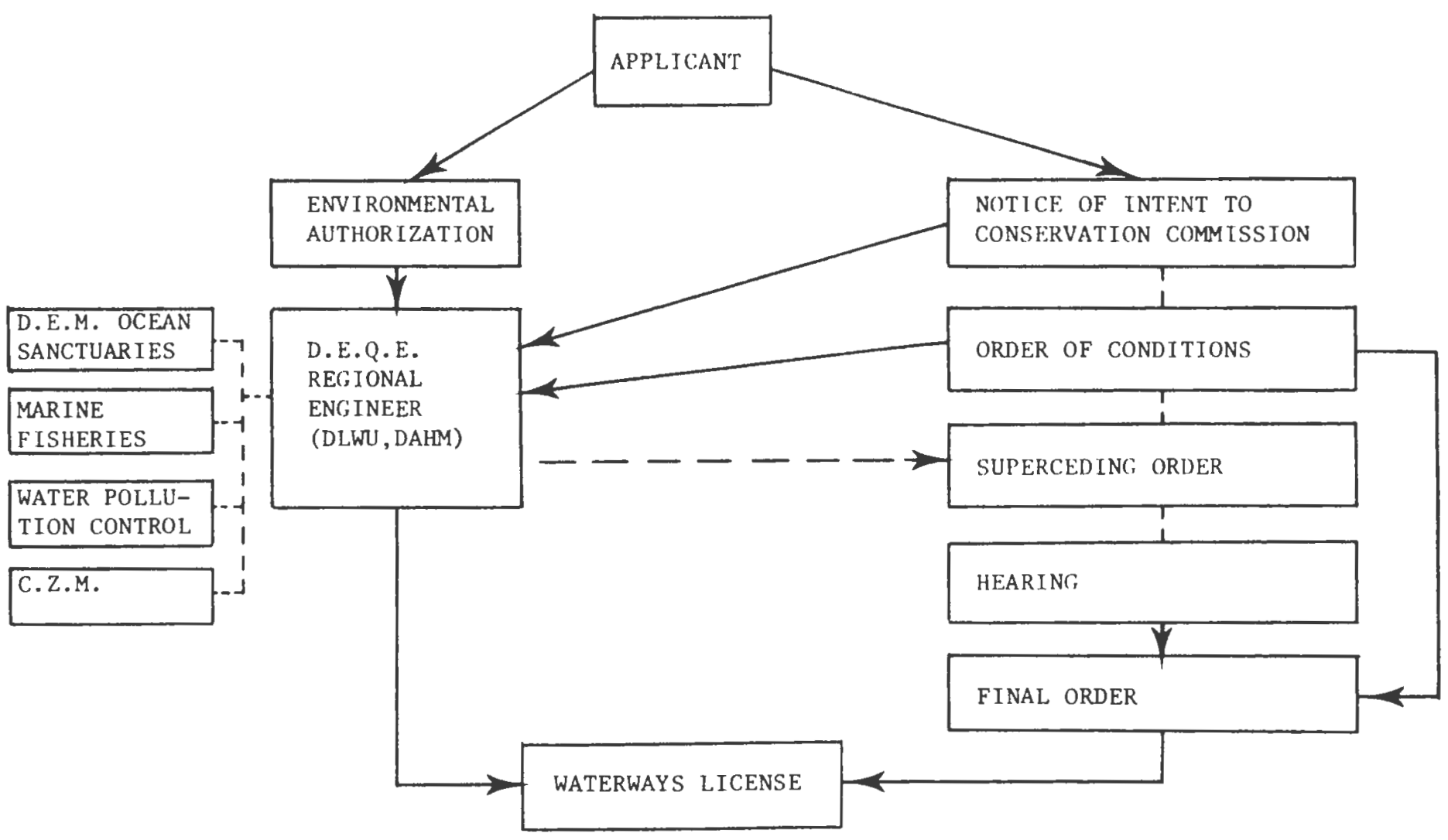

- - - Means may or may not be applicable

Source: Massachusetts Coastal Zone Management Program and Final Environmental Impact Statement, 1978 


\section{Figure E9}

IMPORTANT ADDRESSES AND PHONE NUMBERS

COASTAL RESOURCES MANAGEMENT COUNCIL

Room 508, Veterans Memorial Building

83 Park Street

Providence, Rhode Island 02903

Phone (401) 277-2476

DEPARTMENT OF ENVIRONMENTAL MANAGEMENT

DIVISION OF COASTAL RESOURCES

83 Park Street

Providence, Rhode Island 02903

Phone (401) 277-2476

DEPARTMENT OF ENVIRONMENTAL MANAGEMENT

DIVISION OF IAND RESOURCES

75 Davis Street

Providence, Rhode Is land 02908

Phone (401) 277-2306

NEW ENGLAND DIVISION, ARMY CORPS OF ENGINEERS

424 Trapelo Road

Waltham, Massachusetts 02154

Phone (617) 894-2400

MASSACHUSETTS EXECUTIVE OFFICE OF ENVIRONMENTAL AFFAIRS, OFFICE OF COASTAL ZONE MANAGEMENT

Phone (617) 727-9530 
REFERENCES AND BIBLIOGRAPHY

Adie, Dona ld W., 1975, Marinas, A Working Guide to Their Development And Design, Architectural Press, Ltd., London

American Boat Builders and Repairers Association, 1967, Practices of Boatyard Operation, Bronx, NY

Bourne Zoning Bylaws, 1979, Town of Borne, MA

Callaghan, Dennis W., Comerford, Robert A., and Schwarzbach, Henry (1980) A Manual of Average Financial and Operating Ratios for Southern New England Coastal Marinas and Boatyards, University of Rhode Is land, Marine Technical Report $\equiv_{76}$, (unpub. manuscript, due for pub. 1980)

Chamberlain, Clinton J., 1979, personal communication

Chaney, Charles A., 1961, Marinas: Recommendations for Design, Construction, and Maintenance, NAEBM, NY

Chmura, Gail L., and Ross, Nei1 W., 1978, The Environmenta1 Impact of Marinas and Their Boats, University of Rhode Island, Marine Memorandum 非 5

Collins, Clarkson and Sedgwick, Stephen, 1979, Recreational Boating in Rhode Island's coastal Waters: A Look Forward, University of Rhode Island, Marine Technical Report 非 5

Davis, Albert P., Jr., 1977, Evaluation of Materials for Floating Tire Breakwaters, University of Rhode Island, Marine Technica1 Report 非54

DeChiara, Joseph and Ca1lender, John Hancock, 1973, Time Saver Standards for Building Types, McGraw-Hi11

Dechiara, Joseph and Loppelman, Lee, 1975, Urban Planning and Design Criteria, VanNostrand Rienhold, NY

Della Bitta, Albert J. and Loudon, David L., 1974, Economic Impact: 1973 Newport International Sailboat Show, University of Rhode Is 1 and, Marine Technica1 Report 非27

Della Bitta, Albert J.; Loudon, David L.; Booth, G. Geoffrey; and Weeks, Richard R., 1977, The Economic Impact of the Tal1 Ships '76 Celebration On Rhode Island, University of Rhode Island, Marine Technica1 Report 非 9

Dixon, John Morris, Ed., 1975, "Urban Waterfronts Design and Planning", issue topic, Progressive Architecture, June 1975 
Dodson, John E., Ed., 1961, Coast and Harbor Charts, Stonington Publishing Co., stonington, CT

Dunham, James W. and Finn, Arnold A., 1974, Sma11 Craft Harbors: Design Construction and Operation, US Army Corps of Engineers, Fort Belvior, VA

Emmet, James, Ed., 1973, Waterway Guide, Vol 26, 非, Sidney J. Wain, Annapolis, MD

Encyclopedia of Boating, 1973

Geis, Peter A., Ed., Pub., 1977, 1979, Boating Almanac, Vols 1 and 2, 1977 and 1979, Severna Park, MD

Godfrey, Robert S., Ed., 1978, Building Construction Cost Data for 1978, Robert Snow Means Co., Inc., Duxbury, MA

Goodyear Tire and Rubber Company, 1972, unpublished manuscript

Greenhi11, Basi1, 1976, Archaeology of the Boat, Wesleyan University Press, Middletown, CT

Gunn, Clare A., 1972, Vacationscape: Designing Tourist Regions, University of Texas at Austin

Herbich, John B., and Lou, Jack Y.K., 1977, Protection for Sma11 Craft Marinas, Texas A\&M University

Hirsch, Werner Z., 1973, Urban Economic Analysis, McGraw-Hil1

HUD-FIA, 1976, Flood Boundary Maps, Department of Housing and Urban Development, Flood Insurance Administration

Johns, Warren E. Ed., and others, 1978, Areawide Water Quality Management Program, Preliminary Evaluation, Marinas Task, Rhode Island Statewide Planning Program

Jones, Charles, 1964, "Where Marina Profits Come From, The Boating Industry, August , 1964

Kelley, Robert and Rorholm, Niels, 1974, An Analysis of the Rhode Island Marina Industry, University of Rhode Island, Marine Technical Report 非9

Kenda11, Maurice G., 1943, The Advanced Theory of Statistics, Volume 1, J.B. Lippincott, London(?)

Knetsch, Jack L., 1974, Outdoor Recreation and Water Resources Planning, American Geophysical Union, Washington, DC

Korin, Basil P., 1975, Statistical Concepts for the Social Sciences, Winthrop Publishers, Cambridge, MA 
McConne11, K.E., 1975, Some Problems In Estimating the Demand For Outdoor Recreation, University of Rhode Is land, Marine Reprint $\$ \#_{42}$

McConne11, K.E. and Caswe11, M.F., (no date), Report on A Survey of Rhode Island Households Concerning Their Outdoor Recreational Activities, University of Rhode Island, Marine Memorandum $\left.\right|^{5} 50$

McKeever, J. Ross, Ed., 1968, The Community Builders Handbook, Urban Land Institute, Washington, DC

Metropolitan Area Planning Counci1 (MAPC), 1972, Boston Harbor Islands Comprehensive Plan, Boston

Murphy, William, 1979, NMFS catch statistics, Newport office, personal interview

Onosko, William R., 1968, Water Use Criteria For Boating: A Case Study of Water-Land Use Conflicts in Galilee, Rhode Island, masters thesis, University of Rhode Island

Rhode Island Department of Economic Development, (no date), Boating in Rhode Island, Providence, RI

Rorholm, Niels, 1963, Economic Impact of Narragansett Bay, University of Rhode Island Agricultural Experiment Station, Bulletin 非374

Rorholm, Nie1s, 1976, Boats and Their People: A Study of Rhode Is land Boat

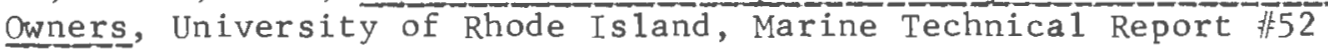

Rosenfeld, Stanley and Taylor, William H., 1958, The Story of American Yachting, Bramhall House, NY

Ross, Neil, 1979, personal communication

Schroter, Bertram (no date), Yacht Harbours - Bases for Planning, Internationaler Arbeitskreis Sportsttattenbau E.V., Koln-Mungersdorf, Germany

Shaw, George and Ross, Nei1, 1977, How To Build A Floating Tire Breakwater, University of Maine/University of New Hampshire Cooperative Institutional Sea Grant Program, Information Bulletin 非

Spaulding, Irving A., (no date), Recreational Adequacy of Beach Activity and Comparative Regulatory Influences, University of Rhode Island, Marine Technica 1 Report 非7

State of Michigan, Department of Natura1 Resources, Waterways Division, (no date), Design Guide For Boat Launch Facilities

Urban Design Group, Inc., 1975, Marinas and Pleasure Boating Facilities Study, Rhode Island Department of Economic Development

U.S. Department of Interior, 1977, Sources of Assistance For Developing Boating Facilities, Washington, DC 
Weiss, Robert S., 1968, Statistics in Social Research, Wiley and Sons, NY

Zinn, Jeffrey A., 1970, The Orientation of Marine Recreation Communities on Upper Buzzards Bay, masters thesis, University of Rhode Island 